\title{
A Nyugat-Mecsek Tájvédelmi Körzet és közvetlen környéke nagylepkéinek (Lepidoptera) áttekintése az 1965 óta végzett megfigyelések alapján
}

\author{
UHERKOVICH Ákos
}

\author{
H-7633 Pécs, Építők útja 3/b. I. 6. \\ e-mail: uhu941@gmail.com
}

\begin{abstract}
UHERKоVich, Á.: Synopsis of the butterflies and larger moths (Lepidoptera) of the Western Mecsek Landscape Protection Area and environs, South Hungary - on the basis of the researches since 1965.

Abstract: Author examined the macrolepidopterous fauna of the Western Mecsek Landscape Protecion area and environs since the year 1965. He collected and studied the butterflies and larger moths of at least forty sites by diurnal collection, on lamps or by semiautomathic light traps. 763 species were detected, 74 of them are protected by law. Two species are protected to a greater extent: Arytrura musculus (Ménétriés, 1859) and Iolana iolas (Ochsenheimer, 1816). A. musculus was proved during the last decade only, and did not become a frequent species, while $I$. iolas was more frequent forty or fifty years ago. The biotopes of latter species have been decreased due both to the expansion of inhabited area and the change the vegetation. Population of several other protected and non-protected species have decreased or those disappeared. There are some, but fewer species which appeared during the last $20 \ldots 30$ years, and they became more or less frequent nowadays. All the collected species of the author and their collecting sites are listed. The protected species were shown by a larger table. The map of collecting sites and some biotope photos were also presented, further pictures of some protected species completed the paper.
\end{abstract}

Keywords: faunistics, long term investigation, proctected species, Hungary

\section{Bevezető}

A Mecsek-hegység nyugati felén 2009-ben alakították ki a Nyugat-Mecsek Tájvédelmi körzetet [a 4/2009. (IV. 10.) KvVM rendelettel], 10.315 hektáron, jóval a Kelet-Mecsek TK megalapítása (1977) után. A tájvédelmi körzet nyugatról keletre Bükkösdtől PécsÁrpádtetőig, északon Orfüig, Abaligetig és Mánfáig, déli irányban pedig Cserkútig, illetve a Pécs feletti parkerdőkig tart, és számos Natura 2000-es besorolású területet foglal magába.

Geológiai felépítése igen változatos, a permtől kezdve (homokkövek) számos földtörténeti korszak rányomta bélyegét erre a tájra (Lovász 1977). Legmagasabb pontja a Pécs felett magasodó Tubes (611 m), és ennél nem sokkal alacsonyabb a Jakab-hegy (592 m), viszont ennek az utóbbinak a kiterjedése és tömege jóval felülmúlja a Misina-Tubes csoportét. Helyenként nagyobb kiterjedésü karsztos felszínek alakultak ki. Mély völgyek erőteljesen tagolják, a völgyek egy részében állandó vízfolyással. Növénytársulástani felépítése rendkívül változatos, flórája és állatvilága nagyon sokszínű, ahogy azt több, alaposabban kikutatott élölény-csoportról szóló cikk is bizonyítja. Az erdőségek nagy hányada különböző tölgyes társulás, ezek összetétele elsősorban a kőzet- és talajviszo- 
nyoktól, valamint a kitettségtől függ. Jelentős területen találunk extrazonális bükkösöket, valamint bükkelegyes tölgyeseket is. A keményfás ligeterdők részaránya alacsony, völgyalji fekvésben lelhetök fel itt-ott, füz-nyár liget pedig még kevesebb helyen.

E helyen nem említeném a korábbi botanikai és zoológiai eredményeket, legfeljebb érintőlegesen utalnék néhány eredményre a lepkék kutatásával kapcsolatban.

A Nyugat-Mecsek Tájvédelmi körzet területére, illetve annak közeli szomszédságára (kb. $1 / 2 \mathrm{~km}$-en belül) a nagy összefoglaló lepkészeti munkák (ABAFI-AIGNER 1907, VARGA 2012) alig adnak meg előfordulási adatokat. Már a XIX. században született néhány kisebb-nagyobb közlemény a pécsi Mecsek lepkéiről, amelyek egyes adatait fenntartással kell fogadnunk. Az is kétségtelen, hogy nemcsak a kutatók ismeretei voltak akkor hiányosabbak, hanem maga a fauna is meglehetősen sokat változott mintegy másfél évszázad alatt. A XX. század közepén Balogh Imre néhány publikációja foglalkozott a terület lepkéivel (pl. BALOGH 1956), valamint viszonylag sok elterjedési adatot találunk Kovács $(1953,1956)$ két cikkében. Utóbbi adatok részben a XIX. századi publikációk revízió után elfogadható adatait tartalmazták, és a „pécsi Mecsekre” vonatkoznak.

\section{Anyag és módszer}

Magam több mint 50 éve, 1965 után kezdtem meg a mecseki lepkefauna tanulmányozását. Ez az első egy-két évben a nappali lepkékre (Diurna) korlátozódott, azonban a hetvenes években már rendszeresen vizsgáltam egyes pontok vagy részterületek teljes nagylepke-faunáját. Ennek eredményeképpen hamarosan összefoglaltam a Pécs feletti karsztbokorerdőkről nyert ismereteinket (UHERKOVICH 1978). Ez után egy tipikus, permi málladékon tenyésző cseres-tölgyesben végzett vizsgálatról írtam (UHERKOVICH 1980). A vizsgálat-sorozat keretében később sor került patakvölgyi bükkösök illetve szurdokerdők faunájának feltárására is (UHERKOVICH 1984). Időközben egy igen tipikus, legelö helyén szukcesszióval létrejött, és folyamatosan változó, mozaikosan fejlődő tövisbozótosban is dolgoztam (UHERKOVICH 1987). Az előbb idézett nagyobb publikációk mellett kisebb cikkek további adatokat is tartalmaztak, ezek felsorolásától itt eltekintek.

Az 1900-as évek utolsó másfél évtizedében, valamint a 2000-es években, egészen napjainkig (2017-ig) különböző intenzitással folytattam a szóban forgó terület lepkészeti kutatását. Összesen 29 lelőhelyen illetve lelőhely-csoportban (egymáshoz közel fekvő, hasonló adottságú gyüjtőpontokon) folyt a vizsgálat a tájvédelmi körzeten belül illetve annak közvetlen szomszédságában (1. ábra).

Ennek egyik jellemző helyszíne volt Pécs városának nyugati része felett elhelyezkedő Deindolok. Itt nappal és fényen megfigyelve sok (529) lepkefajt jegyeztem fel, illetve gyüjtöttem be. A lelőhely a parkerdő és a szőlők határvonalán van, alapvetően mészkövön, sekély termőtalajon. A parkerdő melegkedvelő tölgyes, ezüsthárssal, sommal, kevés gyertyánnal, vadkörtével, madárcseresznyével és madárberkenyével, a közelben néhány bükkel. Sok egykori szőlöparcella évtizedek óta magára hagyva elbozótosodott vagy beerdősült, elsősorban virágos kőris, veresgyürüs som, húsos som, vadkörte, gyepürózsa, kökény, egybibés galagonya változatos állományai, valamint szőlö és gyümölcsfák maradványai alkotják a bozótot. A tisztásokon másodlagos gyepek képződtek, bennük sok kosborfélével. A müvelés alatt álló telkeken a szokásos szőlö- és gyümölcsültetvényeken kívül díszfák, díszbokrok találhatók, többféle tülevelüvel.

Ezen a ponton 1985 óta folyik a fauna felmérése. A kilencvenes évek közepéig, majd 2011-töl az észlelt illetve gyüjtött lepkefajokról (többnyire kvantitatív) lista készült. 


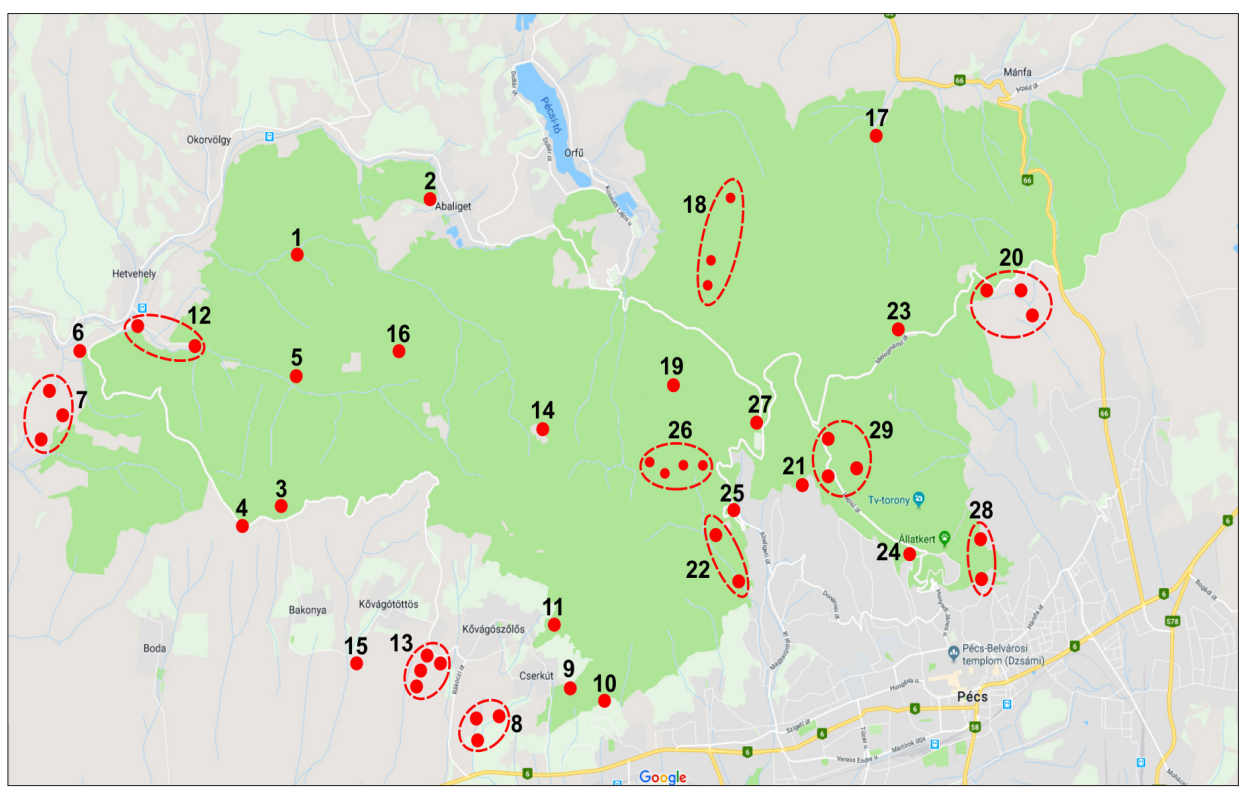

1. ábra: A Nyugat-Mecsek Tájvédelmi körzet és környéke jelen munkában szereplő lelőhelyei.

1 Abaliget, Nyáras-völgy; 2 Abaliget, üdülők; 3 Bakonya, erdészház; 4 Bakonya, Nagy-Rege; 5 Bakonya, Sásvölgy; 6 Bükkösd, Bükkösdi-völgy; 7 Bükkösd, Szentdomján; 8 Cserkút, Cserkúti-dombok; 9 Cserkút DK; 10 Cserkút, Szentmiklós; 11 Cserkút, vízmü és környéke; 12 Hetvehely, Bükkösdi-völgy; 13 Kővágószőlős, Kajdács-dủlő; 14 Kővágószőlős, Petőc-akna; 15 Kővágótöttös, Bicsérdi-vízfolyás; 16 Kővágótöttös, Csermahegy; 17 Mánfa, Nagy-Mély-völgy; 18 Orfü, Cigány-hegy; 19 Orfü, Vörös-hegy; 20 Pécs, Árpádtető; 21 Pécs, Deindol; 22 Pécs, Éger-völgy; 23 Pécs, Kereszt-kunyhó; 24 Pécs, Mandulás; 25 Pécs, Mecsekszentkút, erdészház; 26 Pécs, Mecsekszentkút, Szunyola; 27 Pécs, Remeterét; 28 Pécs, Tettye; 29 Pécs, Tubes.

A gyüjtést itt is - mint máshol az éjjeli nagylepkék esetében - higanygőzlámpával végeztem $(125 \mathrm{~W})$, illetve sokszor használtam automata fénycsapdát különbözö lámpatípusokkal (80, 125 vagy $160 \mathrm{~W}$, és $125 \mathrm{~W}$ „black light” higanygőzlámpa). (2. ábra.)

A nyolcvanas évek első felének rendszeres gyüjtései (UHERKOviCH 1987) után mintegy harminc évvel, 2011 és 2017 között ismét rendszeresen gyüjtöttem Cserkúttól délnyugatra, a Cserkúti-dombok kökény-galagonya-rózsa bozótjának tisztásain, cseres-tölgyes erdő szomszédságában vagy pedig magában az erdőben. Az itteni gyüjtések nem titkolt célja éppen az volt, hogy a korábbi cserkúti vizsgálatok eredményeihez képest lássuk a fauna változását. Csaknem olyan nagy fajszámú anyagot nyertünk, mint a korábbi vizsgálatok alatt (389 illetve korábban 443 faj).

Egy hasonló, de még alig bozótosodott területen, ettől pár kilométerre, Kővágószőlőstől délnyugatra a 2010-es években két évig ugyancsak rendszeres mintavételek folytak, mérsékeltebb fajszám (260 faj) kimutatásával.

A hetvenes években a bakonyai erdészháznál rendszeres személyes mintavételeim voltak, amelyek 247 fajt eredményeztek (UHERKOVICH 1980). Legújabban pedig ettől a helytől délnyugatra, egy egykori legelön - amely napjainkban egy „karbantartott” irtás (azaz nem engedik felnőni a cserjéket) - 2017-ben egész év folyamán rendszeresen mintáztam, ezek a gyüjtések összességében 262 fajt eredményeztek (4. ábra). 
A mecsekszentkúti, egykori erdészháztól északnyugatra fekvő légakna környékén és tőle nyugatra - több ponton is - vizsgálódtam a 2010-es években, ennek eredménye 316 lepkefaj kimutatása volt.

2004-ben Bükkösd és Hetvehely környékének több pontján rendszeresen gyüjtöttem. A Bükkösdi-völgyben, Bükkösd határában a fajszám 282 volt; Szentdomján körül és a Bükkösdi-völgy hetvehelyi szakaszán - a kisebb mintaszámnak is köszönhetően - nem érte el a kétszázat.

Számos más pontot is felkerestem, kisebb-nagyobb rendszerességgel, de azokon a helyeken (vö. 1. ábra) az összesített fajszám általában 200 alatt maradt, nem a hely kisebb fajgazdagsága, hanem inkább az alacsony mintaszám miatt.

Külön meg kell említenem Ötvös Károly „gyüjtőtevékenységét”, aki fényképezőgépével rendszeresen dokumentált az abaligeti üdülöterületen, a tájvédelmi körzet északi peremén. Esténként, higanygőzlámpával kivilágított terraszán éveken keresztül (20082017) fényképezte a berepülő lepkéket. A fényképeken szereplő fajok meghatározását magam vállaltam. A rendkívül jó, sőt sok esetben kifejezetten művészi színvonalú képek alapján a lepkék többségét meg tudtam határozni. Ilyen módon onnét 327 fajt azonosítottam 10 szezon alatt.

\section{Eredmények}

Ebben a fejezetben bemutatom az összes gyüjtött nagylepkefajt, lelöhelyeikkel együtt. Több esetben két vagy több lelöhelyet - amelyek egymáshoz közel $(<0,5 \mathrm{~km})$ voltak és azonos település határába estek - összevontam. Mind a lámpás gyüjtéseknél, mind pedig a nappalilepke megfigyeléseknél nincs jelentősége, vagy legalábbis elhanyagolható párszáz méteres távolság, hiszen sok lepkefaj még ennél nagyobb távolságból kerülhet látókörünkbe (1. ábra).

Az anyag jellemzőbb és ritkább fajainak bizonyító példányai két múzeumi gyűjteménybe kerültek. A XX. századi anyag a pécsi Janus Pannonius Múzeum Természettudományi osztályának a gyüjteményében található, a kétezres években a kaposvári Rippl-Rónai Múzeum gyüjteményét gyarapítottam jelentősebb, ezres nagyságrendü lepkeanyaggal.

Az lelöhelyek (vagy lelöhely-csoportok) mellett nem adom meg a gyüjtés dátumát, a gyüjtő személyét és a példányszámot sem. Ezt a terjedelem sem engedné meg, hiszen a gyakoribb fajok a rendszeresen kutatott pontokon akár 20-30 esetben is elökerültek. A gyüjtő legtöbb esetben maga a szerző, tehát ennek jelölése is felesleges, az Abaliget, üdülők „lelőhelyen” pedig Ötvös Károly fényképezett. A jegyzékben ugyancsak nem jelölöm, ha az adat már publikált. Négy nagyobb cikkem (UHERKovicH 1978, 1980, 1984, 1987) - és néhány kisebb - számos lentebb idézett adatot tartalmaz.

Az elmúlt 50 év alatt a mértékadó nevezéktan többször is változott. Ezt figyelembe véve a jelenben legkorszerübbnek számító „Magyarország nagylepkéi” című munka 2. kiadásának nevezéktanát illetve rendszerét követem (VARGA 2012). Több esetben, a fajjegyzék könnyebb használhatósága érdekében megadom a korábban használt (szinonim) neveket. Alcsalád neveket csak néhány nagyobb fajszámú család (Geometridae, Erebidae, Noctuidae, Nymphalidae) esetén tüntetek fel. 


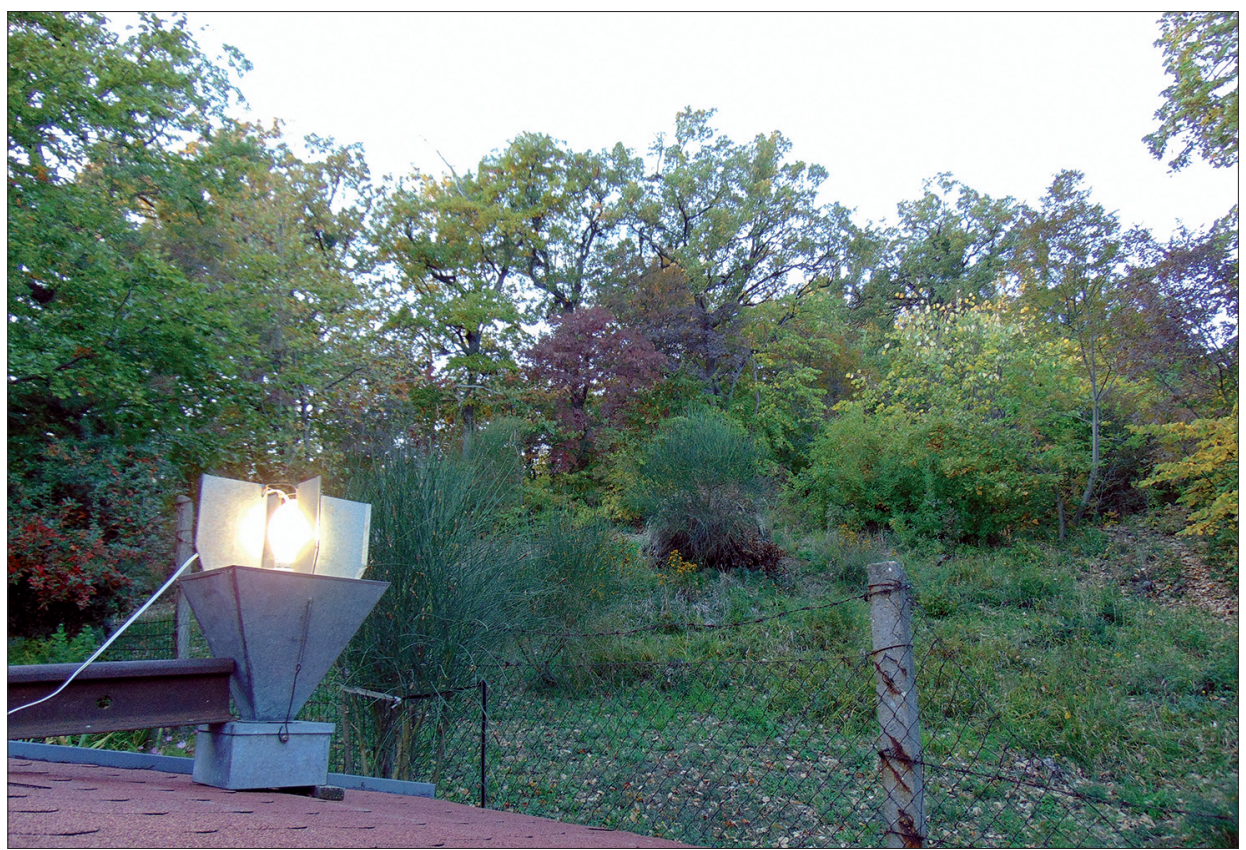

2. ábra: Hordozható fénycsapda Pécs Deindolban, a háttérben egy elhagyott szőlő helyén kiirtott bozót, mögötte melegkedvelő tölgyes.

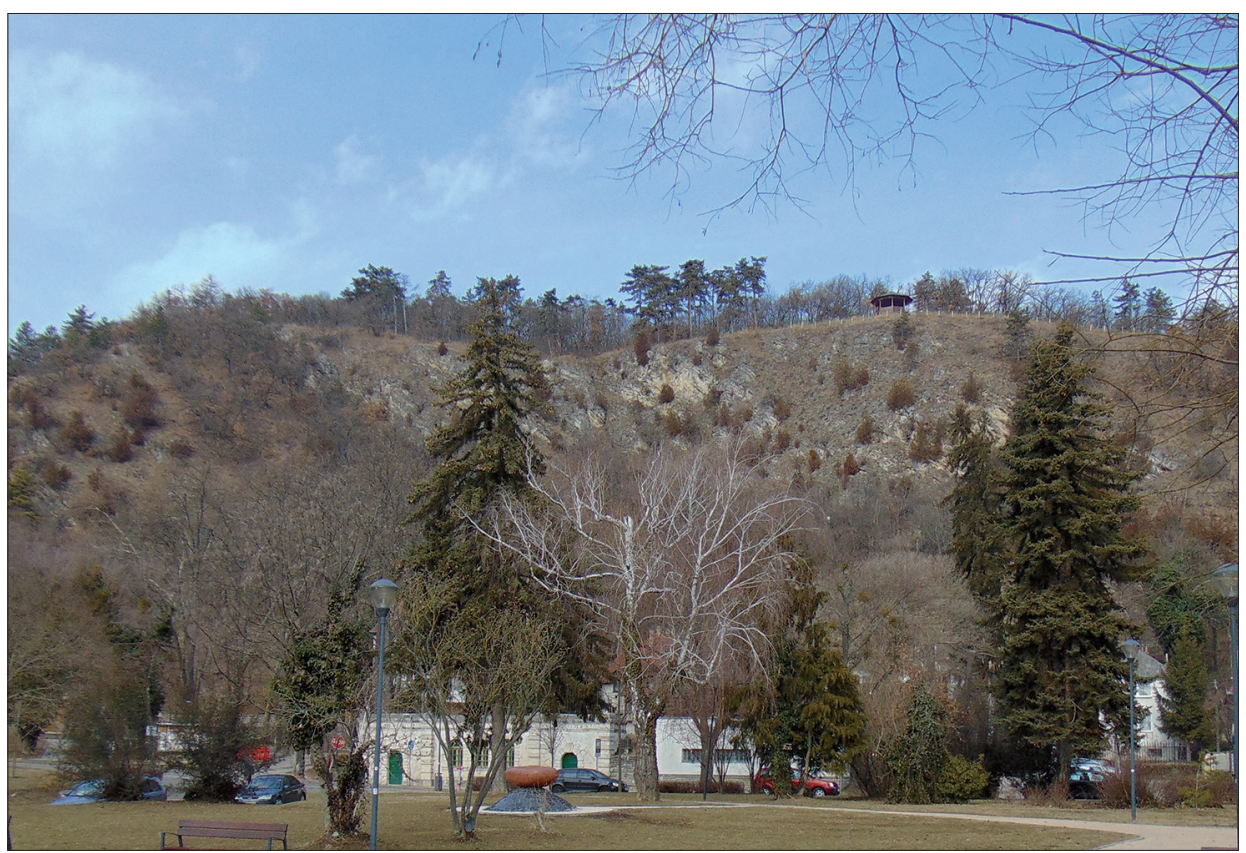

3. ábra: A pécsi Tettye feletti meredek sziklás lejtő, a hetvenes évekbeli gyűjtések közelében. 


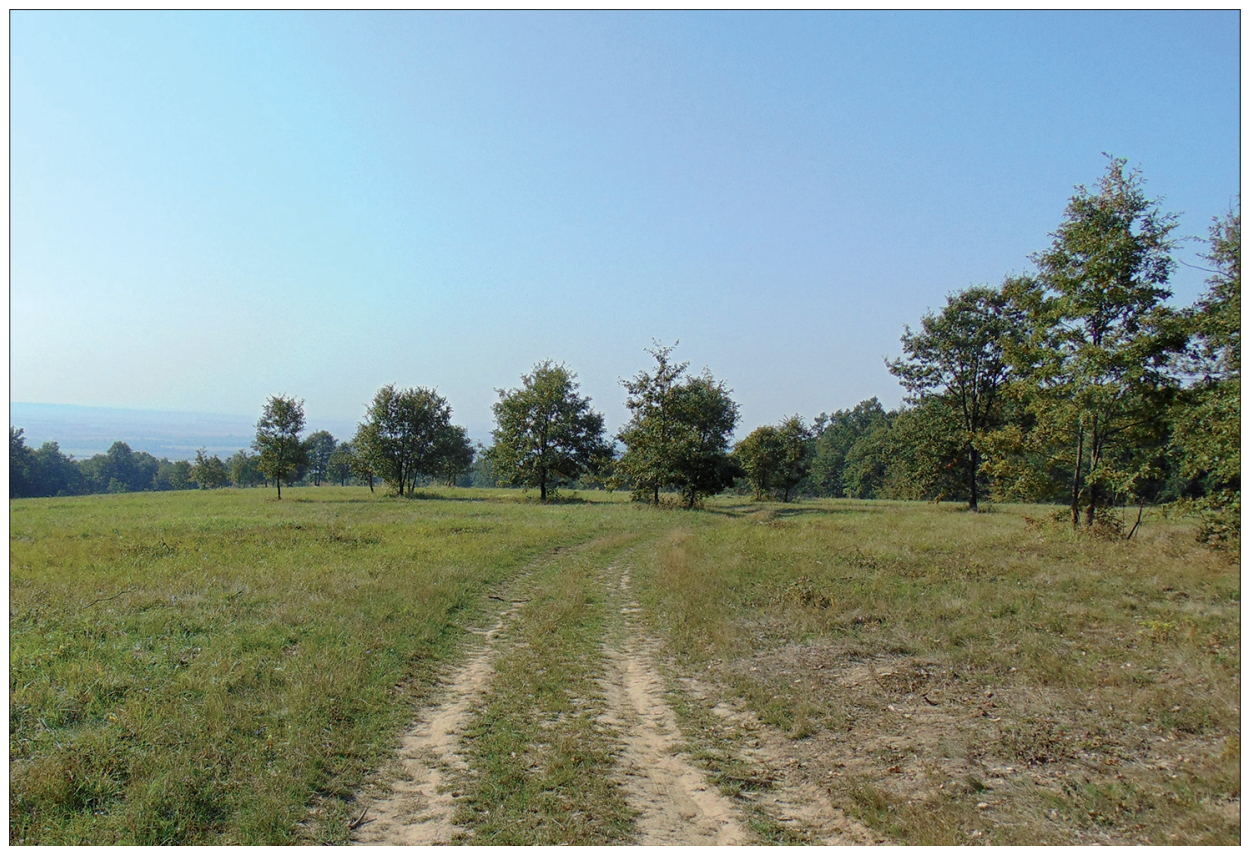

4. ábra: Cseres-tölgyes irtása, az egyik rendszeresen felkeresett éjjeli gyưjtőhely (Bakonya, Nagy-Rege).

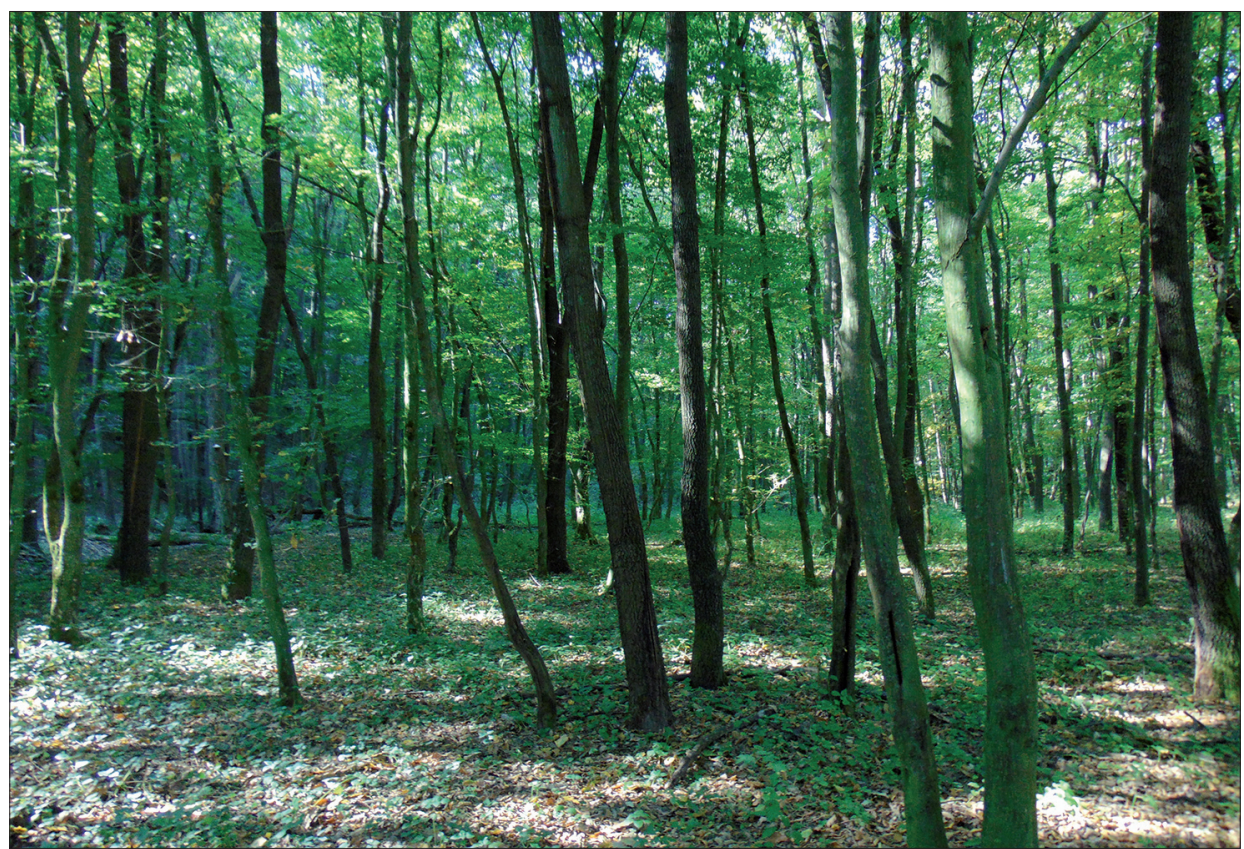

5. ábra: Völgyalji, középkorú keményfájú liget az abaligeti Nyáras-völgyben. 


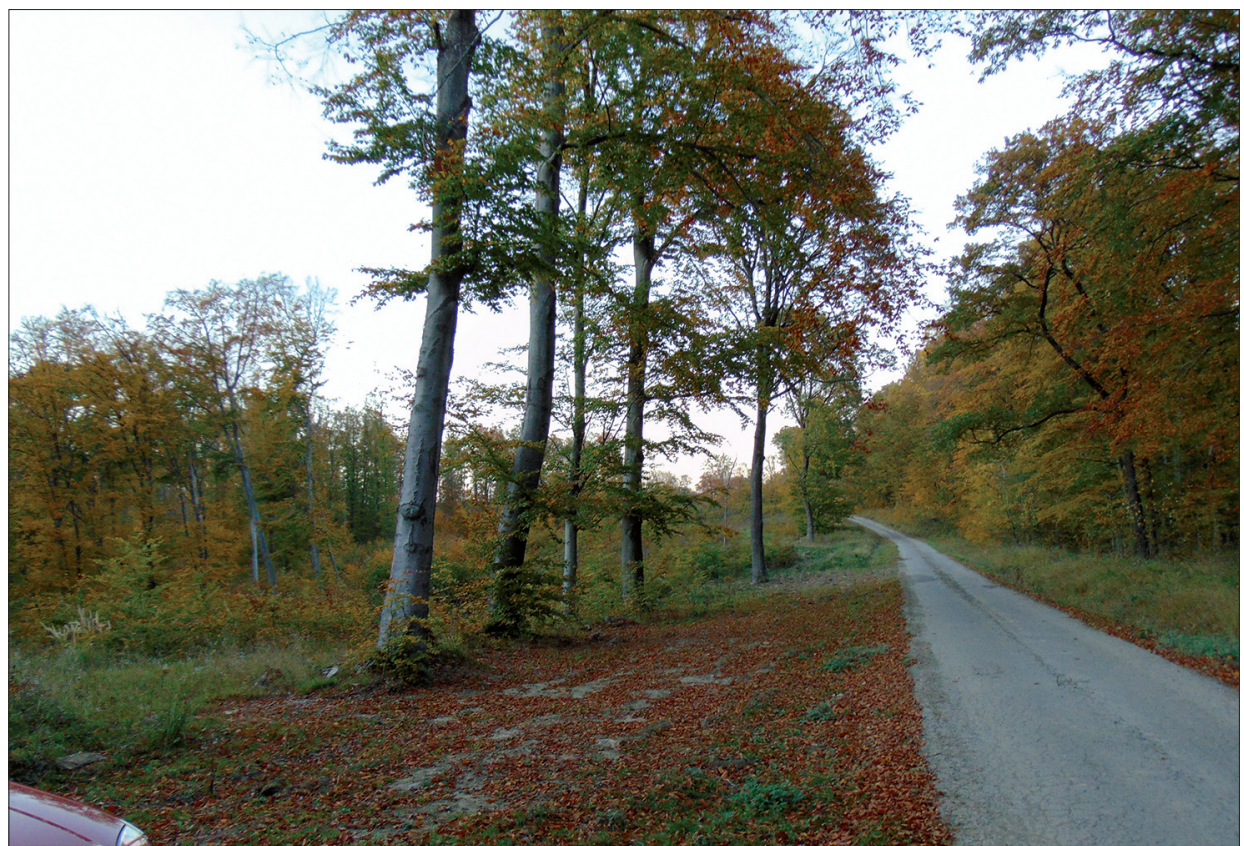

6. ábra: Orfü, Cigány-hegy, a Lóri kulcsosházhoz vezető út.

Bükkelegyes gyertyános-tölgyes és irtása.

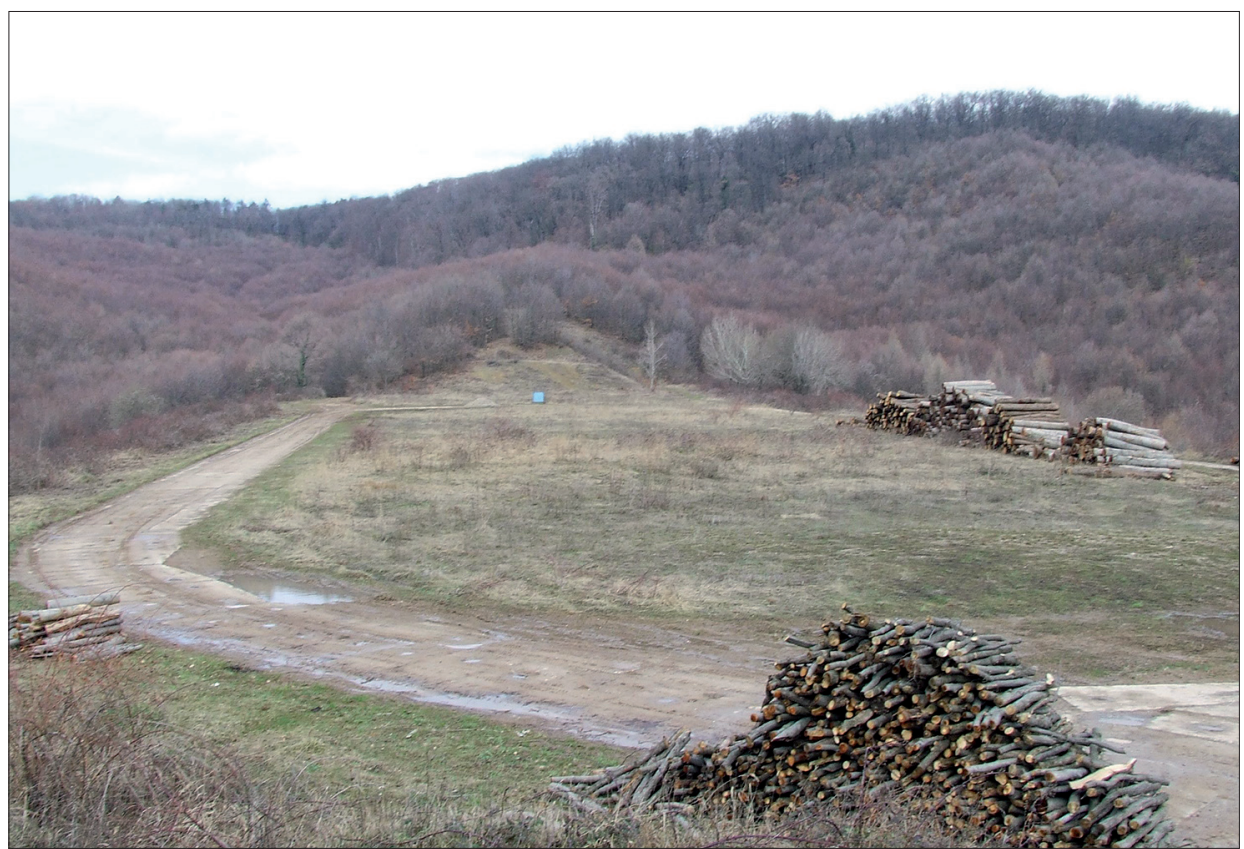

7. ábra: Pécs, Mecsekszentkút, Szunyola, az egykori légakna rekultivált helyszíne. 


\section{A gyüjtött fajok és elterjedési adataik}

\section{Lasiocampidae}

Malacosoma neustria (Linnaeus, 1758) - Cserkút, DK; Cserkút, Szentmiklós.

Trichiura crataegi (Linnaeus, 1758) - Abaliget, üdülők; Bakonya, erdészház; Cserkút, Szentmiklós; Kővágószőlős, Kajdács-dülő; Pécs, Éger-v.; Pécs, Tettye.

Poecilocampa populi (Linnaeus, 1758) - Abaliget, üdülök; Bakonya, erdészház; Cserkút, DK; Cserkút, Szentmiklós; Mánfa, Nagy-Mély-v.

Eriogaster catax (Linnaeus, 1758) - Cserkút, DK; Kővágószőlős, Kajdács-dűlő.

Eriogaster lanestris (Linnaeus, 1758) - Cserkút, DK; Kővágószőlős, Kajdács-dűlő; Pécs, Deindol.

Euthrix potatoria (Linnaeus, 1758) - Abaliget, üdülök; Cserkút, Cserkúti-dombok.

Odonestis pruni (Linnaeus, 1758) - Abaliget, üdülők; Bakonya, Nagy-Rege; Cserkút, Cserkúti-dombok;

Cserkút, DK; Mánfa, Nagy-Mély-v.; Pécs, Mecsekszentkút, Szunyola.

Lasiocampa quercus (Linnaeus, 1758) - Cserkút, Cserkúti-dombok; Cserkút, DK.

Lasiocampa trifolii ([Denis \& Schiffermüller], 1775) (= Pachygastria t.) - Abaliget, Nyáras-v.; Abaliget, üdülők; Bakonya, erdészház; Bakonya, Nagy-Rege; Bükkösd, Szentdomján; Cserkút, Cserkúti-dombok; Cserkút, DK; Cserkút, Szentmiklós; Hetvehely, Bükkösdi-v.; Kővágószőlős, Kajdács-dűlő; Mánfa, NagyMély-v.

Macrothylacia rubi (Linnaeus, 1758) - Abaliget, Nyáras-v.; Abaliget, üdülők; Bakonya, erdészház; Bakonya, Nagy-Rege; Bükkösd, Bükkösdi-v.; Cserkút, Cserkúti-dombok; Cserkút, DK; Cserkút, Szentmiklós; Kővágószőlős, Kajdács-dülő; Mánfa, Nagy-Mély-v.; Orfü, Cigány-h.; Pécs, Deindol.

Dendrolimus pini (Linnaeus, 1758) - Hetvehely, Bükkösdi-v.

Gastropacha populifolia ([Denis \& Schiffermüller], 1775) - Cserkút, DK.

Gastropacha quercifolia (Linnaeus, 1758) - Bakonya, Nagy-Rege; Cserkút, Cserkúti-dombok; Cserkút, Szentmiklós; Kővágószőlős, Kajdács-dűlő.

Phyllodesma tremulifolia (Hübner, 1810) (=Epicnaptera t.) - Bakonya, erdészház; Bakonya, Nagy-Rege; Bakonya, Sás-v.; Bükkösd, Bükkösdi-v.; Cserkút, Cserkúti-dombok; Cserkút, DK; Cserkút, Szentmiklós; Hetvehely, Bükkösdi-v.; Kővágószőlős, Petőc-akna; Pécs, Deindol; Pécs, Mecsekszentkút, erdészház; Pécs, Mecsekszentkút, Szunyola; Pécs, Tettye.

\section{Sphingidae}

Acherontia atropos (Linnaeus, 1758) - Cserkút, DK.

Agrius convolvuli (Linnaeus, 1758) (=Herse c.) - Abaliget, üdülők; Cserkút, DK; Pécs, Deindol.

Sphinx ligustri Linnaeus, 1758 - Bakonya, Nagy-Rege; Cserkút, Cserkúti-dombok; Cserkút, DK; Cserkút, Szentmiklós; Hetvehely, Bükkösdi-v.; Kővágószőlős, Kajdács-dülő; Pécs, Deindol; Pécs, Mecsekszentkút, Szunyola; Pécs, Tettye.

Hyloicus pinastri (Linnaeus, 1758) - Abaliget, üdülök; Bükkösd, Bükkösdi-v.; Cserkút, Cserkúti-dombok; Cserkút, DK; Cserkút, Szentmiklós; Hetvehely, Bükkösdi-v.; Mánfa, Nagy-Mély-v.; Pécs, Deindol; Pécs, Mecsekszentkút, Szunyola; Pécs, Tettye.

Laothoe populi (Linnaeus, 1758) - Abaliget, üdülők; Cserkút, Cserkúti-dombok; Cserkút, DK; Cserkút, Szentmiklós; Mánfa, Nagy-Mély-v.; Pécs, Deindol.

Marumba quercus ([Denis \& Schiffermüller], 1775) - Bakonya, Nagy-Rege; Cserkút, Cserkúti-dombok; Cserkút, DK; Cserkút, Szentmiklós; Pécs, Deindol; Pécs, Mecsekszentkút, Szunyola.

Mimas tiliae (Linnaeus, 1758) - Abaliget, Nyáras-v.; Abaliget, üdülők; Bakonya, erdészház; Bakonya, Nagy-Rege; Bakonya, Sás-v.; Bükkösd, Bükkösdi-v.; Bükkösd, Szentdomján; Cserkút, Cserkúti-dombok; Cserkút, DK; Cserkút, Szentmiklós; Hetvehely, Bükkösdi-v.; Kővágószőlős, Kajdács-dűlő; Kővágószőlős, Petőc-akna; Mánfa, Nagy-Mély-v.; Pécs, Deindol; Pécs, Mecsekszentkút, Szunyola.

Smerinthus ocellata (Linnaeus, 1758) - Bükkösd, Szentdomján; Cserkút, Cserkúti-dombok; Pécs, Mecsekszentkút, Szunyola. 


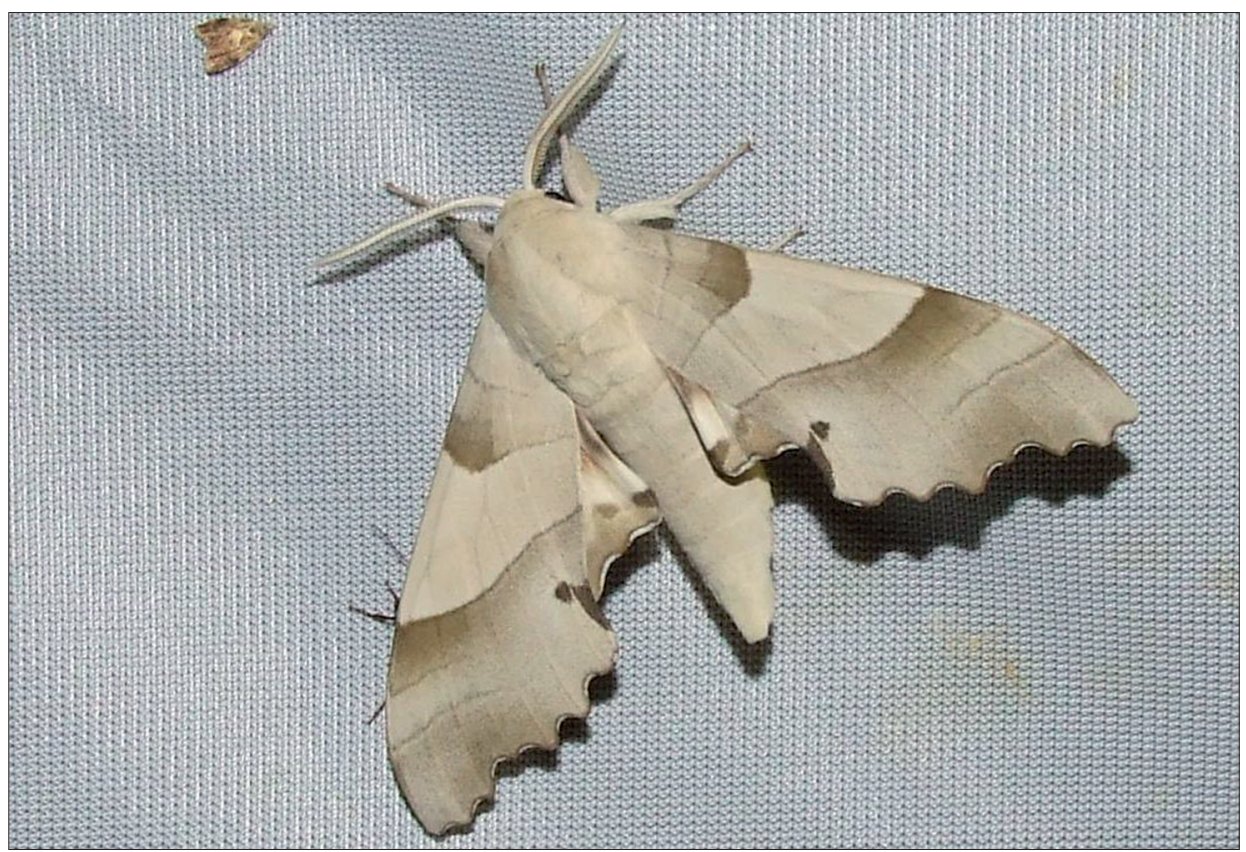

8. ábra: Marumba quercus ([Denis \& Schiffermüller], 1775) (fotó: Uherkovich Ákos)

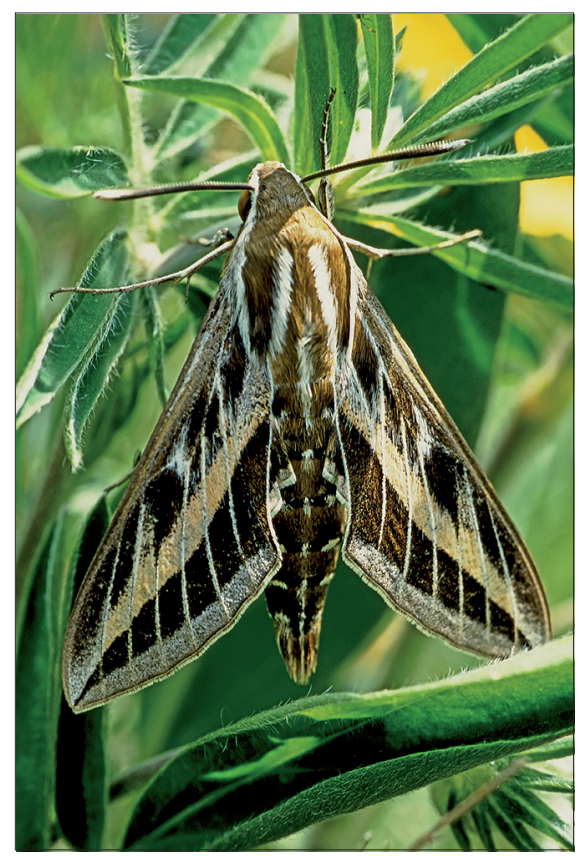

9. ábra: Hyles livornica (Esper, 1779) (fotó: Ötvös Károly) 


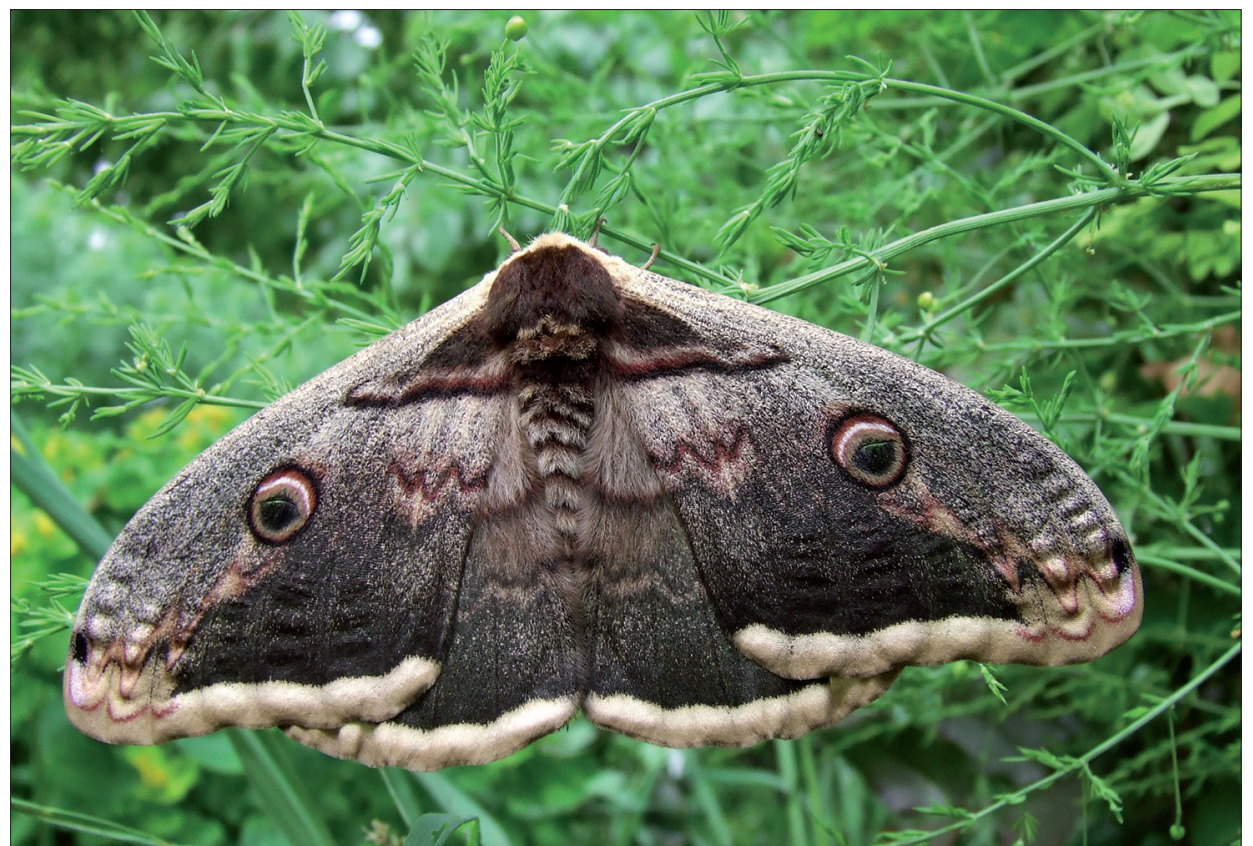

10. ábra: Saturnia pyri ([Denis \& Schiffermüller], 1775) (fotó: Uherkovich Ákos)

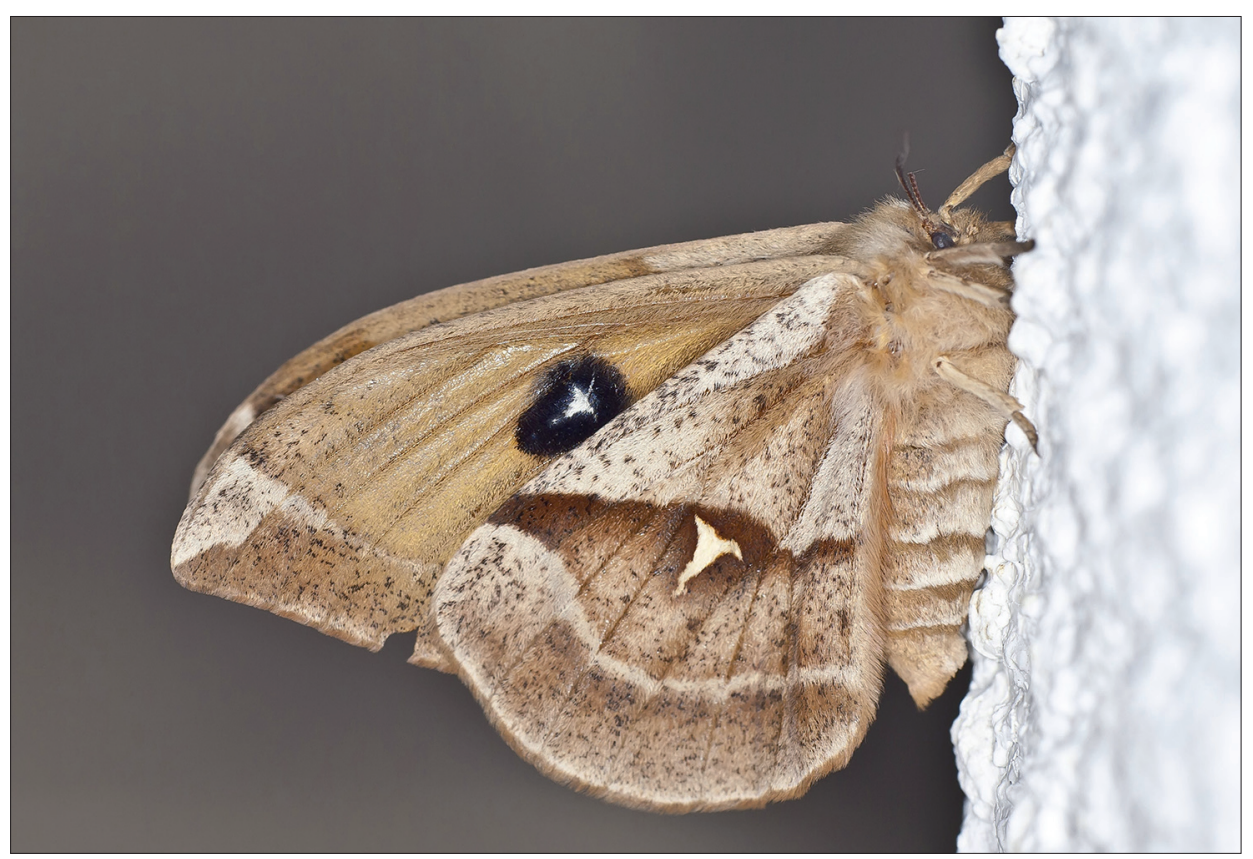

11. ábra: Aglia tau (Linnaeus, 1758)

(fotó: Ötvös Károly) 
Macroglossum stellatarum (Linnaeus, 1758) - Abaliget, üdülők; Bükkösd, Bükkösdi-v.; Bükkösd, Szentdomján; Cserkút, Cserkúti-dombok; Pécs, Deindol; Pécs, Éger-v.; Pécs, Mecsekszentkút, Szunyola.

Proserpinus proserpina (Pallas, 1772) - Bakonya, erdészház; Cserkút, Cserkúti-dombok; Cserkút, Szentmiklós; Hetvehely, Bükkösdi-v.

Deilephila elpenor (Linnaeus, 1758) (= Pergesa e.) - Abaliget, Nyáras-v.; Bakonya, erdészház; Bakonya, Nagy-Rege; Cserkút, Cserkúti-dombok; Cserkút, Szentmiklós; Hetvehely, Bükkösdi-v.; Kővágószőlős, Kajdács-dűlö; Pécs, Deindol; Pécs, Mecsekszentkút, Szunyola.

Deilephila porcellus (Linnaeus, 1758) (= Pergesa p.) - Abaliget, Nyáras-v.; Abaliget, üdülők; Bakonya, erdészház; Bakonya, Nagy-Rege; Bükkösd, Bükkösdi-v.; Bükkösd, Szentdomján; Cserkút, Cserkúti-dombok; Cserkút, DK; Cserkút, Szentmiklós; Hetvehely, Bükkösdi-v.; Kővágószőlős, Kajdács-dủlő; Kővágószőlős, Petőc-akna; Mánfa, Nagy-Mély-v.; Pécs, Deindol; Pécs, Mecsekszentkút, erdészház; Pécs, Mecsekszentkút, Szunyola; Pécs, Tettye.

Hyles euphorbiae (Linnaeus, 1758) (= Celerio e.) - Bükkösd, Bükkösdi-v.; Cserkút, Cserkúti-dombok; Cserkút, DK; Cserkút, Szentmiklós; Kővágószőlős, Kajdács-dűlö; Pécs, Deindol; Pécs, Tettye.

Hyles livornica (Esper, 1779) - Pécs, Mandulás.

\section{Saturniidae}

Antherea yamamai (Guérin-Méneville, 1861) - Abaliget, üdülők; Bükkösd, Szentdomján; Cserkút, Cserkútidombok; Hetvehely, Bükkösdi-v.; Kővágószőlös, Petöc-akna; Kővágótöttös, Cserma-h.; Pécs, Deindol; Pécs, Éger-v.; Pécs, Mecsekszentkút, Szunyola.

Saturnia pavoniella (Scopoli, 1763) (= Eudia pavonia (Linnaeus, 1758)) - Bükkösd, Szentdomján; Cserkút, Cserkúti-dombok; Cserkút, DK; Hetvehely, Bükkösdi-v.; Kővágószőlős, Kajdács-dűlő; Mánfa, Nagy-Mély-v.; Pécs, Deindol.

Saturnia pyri ([Denis \& Schiffermüller], 1775) - Abaliget, üdülők; Bükkösd, Bükkösdi-v.; Pécs, Deindol; Pécs, Tettye; Pécs, Tubes.

Aglia tau (Linnaeus, 1758) - Abaliget, Nyáras-v.; Abaliget, üdülök; Bakonya, erdészház; Bükkösd, Bükkösdi-v.; Cserkút, DK; Hetvehely, Bükkösdi-v.; Mánfa, Nagy-Mély-v.; Pécs, Deindol; Pécs, Éger-v.; Pécs, Mecsekszentkút, Szunyola.

\section{Drepanidae}

Cilix glaucata (Scopoli, 1763) - Abaliget, üdülök; Bakonya, erdészház; Bükkösd, Bükkösdi-v.; Cserkút, Cserkúti-dombok; Cserkút, DK; Cserkút, Szentmiklós; Kővágószőlős, Kajdács-dűlő; Pécs, Deindol; Pécs, Mecsekszentkút, Szunyola; Pécs, Tettye.

Drepana curvatula (Borkhausen, 1790) - Abaliget, Nyáras-v.; Mánfa, Nagy-Mély-v.

Drepana falcataria (Linnaeus, 1758) - Abaliget, Nyáras-v.; Abaliget, üdülők; Hetvehely, Bükkösdi-v.; Kővágótöttös, Cserma-h.; Mánfa, Nagy-Mély-v.; Pécs, Éger-v.

Sabra harpagula (Esper, 1786) (= Drepana h.) - Abaliget, Nyáras-v.; Abaliget, üdülök; Bakonya, NagyRege; Bakonya, Sás-v.; Bükkösd, Bükkösdi-v.; Cserkút, Cserkúti-dombok; Cserkút, DK; Cserkút, Szentmiklós; Hetvehely, Bükkösdi-v.; Mánfa, Nagy-Mély-v.; Orfü, Cigány-h.; Pécs, Deindol; Pécs, Mecsekszentkút, erdészház.

Watsonalla binaria (Hufnagel, 1767) (= Drepana b.) - Abaliget, Nyáras-v.; Abaliget, üdülök; Bakonya, erdészház; Bakonya, Nagy-Rege; Bükkösd, Bükkösdi-v.; Cserkút, Cserkúti-dombok; Cserkút, DK; Cserkút, Szentmiklós; Hetvehely, Bükkösdi-v.; Kővágószőlős, Petőc-akna; Kővágótöttös, Cserma-h.; Mánfa, NagyMély-v.; Orfü, Cigány-h.; Pécs, Deindol; Pécs, Mecsekszentkút, erdészház; Pécs, Mecsekszentkút, Szunyola; Pécs, Tettye; Pécs, Tubes.

Watsonalla cultraria (Fabricius, 1775) (= Drepana c.) - Abaliget, Nyáras-v.; Abaliget, üdülők; Bakonya, erdészház; Bakonya, Nagy-Rege; Bakonya, Sás-v.; Bükkösd, Bükkösdi-v.; Kővágószőlős, Petőc-akna; Kővágótöttös, Cserma-h.; Mánfa, Nagy-Mély-v.; Orfü, Cigány-h.; Pécs, Deindol; Pécs, Éger-v.; Pécs, Mecsekszentkút, erdészház; Pécs, Mecsekszentkút, Szunyola. 


\section{Thyatiridae (Tetheidae)}

Thyatira batis (Linnaeus, 1758) - Abaliget, Nyáras-v.; Abaliget, üdülők; Bakonya, erdészház; Bakonya, Nagy-Rege; Bükkösd, Bükkösdi-v.; Bükkösd, Szentdomján; Cserkút, Cserkúti-dombok; Cserkút, DK; Hetvehely, Bükkösdi-v.; Kővágószőlős, Kajdács-dűlő; Kővágótöttös, Cserma-h.; Mánfa, Nagy-Mély-v.; Orfü, Cigány-h.; Pécs, Deindol; Pécs, Mecsekszentkút, Szunyola; Pécs, Tettye.

Tethea ocularis (Linnaeus, 1767) - Abaliget, üdülők; Bakonya, Nagy-Rege; Cserkút, Cserkúti-dombok; Kővágószőlős, Kajdács-dülő; Kővágószőlős, Petőc-akna; Pécs, Mecsekszentkút, Szunyola.

Tethea or ([Denis \& Schiffermüller], 1775) - Abaliget, üdülők; Bakonya, erdészház; Bakonya, Nagy-Rege; Bükkösd, Szentdomján; Cserkút, Cserkúti-dombok; Cserkút, DK; Hetvehely, Bükkösdi-v.; Kővágószőlős, Petőc-akna; Orfü, Cigány-h.; Pécs, Deindol; Pécs, Mecsekszentkút, Szunyola.

Ochropacha duplaris (Linnaeus, 1761) (= Tethea d.) - Cserkút, DK.

Habrosyne pyritoides (Hufnagel, 1766) - Abaliget, Nyáras-v.; Abaliget, üdülők; Bakonya, Nagy-Rege; Bakonya, Sás-v.; Bükkösd, Bükkösdi-v.; Bükkösd, Szentdomján; Cserkút, Cserkúti-dombok; Cserkút, DK; Cserkút, Szentmiklós; Kővágószőlős, Kajdács-dűlő; Kővágószőlős, Petőc-akna; Kővágótöttös, Cserma-h.; Mánfa, Nagy-Mély-v.; Orfü, Cigány-h.; Pécs, Deindol; Pécs, Mecsekszentkút, erdészház; Pécs, Mecsekszentkút, Szunyola; Pécs, Tettye; Pécs, Tubes.

Polyploca ridens (Fabricius, 1787) - Abaliget, Nyáras-v.; Abaliget, üdülők; Bakonya, erdészház; Cserkút, Cserkúti-dombok; Cserkút, DK; Kővágószőlős, Kajdács-dűlő; Kővágótöttös, Bicsérdi-vízf.; Mánfa, NagyMély-v.; Orfü, Cigány-h.; Pécs, Árpád-tető; Pécs, Deindol; Pécs, Mecsekszentkút, Szunyola.

Cymatophorina diluta ([Denis \& Schiffermüller], 1775) (=Polyploca d.) - Bakonya, erdészház; Bakonya, Nagy-Rege; Cserkút, Cserkúti-dombok; Cserkút, DK; Cserkút, Szentmiklós; Kővágószőlős, Kajdács-dülő; Mánfa, Nagy-Mély-v.; Orfü, Cigány-h.; Pécs, Deindol; Pécs, Éger-v.; Pécs, Mecsekszentkút, Szunyola; Pécs, Tettye.

Asphalia ruficollis ([Denis \& Schiffermüller], 1775) (= Polyploca r.) - Bakonya, erdészház; Bükkösd, Szentdomján; Cserkút, Cserkúti-dombok; Kővágószőlős, Kajdács-dűlő; Pécs, Árpád-tető; Pécs, Deindol; Pécs, Mecsekszentkút, Szunyola.

\section{Geometridae \\ Archieariinae}

Archiearis notha (Hübner, 1803) - Cserkút, Cserkúti-dombok; Orfü, Vörös-h.; Pécs, Deindol.

\section{Orthostixinae}

Orthostixis cribraria (Hübner, 1799) - Cserkút, DK; Cserkút, Szentmiklós; Mánfa, Nagy-Mély-v.

\section{Alsophilinae}

Alsophila aescularia ([Denis \& Schiffermüller], 1775) - Bakonya, erdészház; Bükkösd, Bükkösdi-v.; Cserkút, Cserkúti-dombok; Cserkút, DK; Cserkút, vízmű környék; Mánfa, Nagy-Mély-v.; Orfü, Cigány-h.; Pécs, Árpádtető; Pécs, Deindol; Pécs, Éger-v.; Pécs, Mecsekszentkút, erdészház; Pécs, Mecsekszentkút, Szunyola; Pécs, Tettye.

Alsophila aceraria ([Denis \& Schiffermüller], 1775) (= quadripunctaria) - Abaliget, üdülök; Bakonya, erdészház; Cserkút, DK; Cserkút, Szentmiklós; Mánfa, Nagy-Mély-v.; Orfü, Cigány-h.; Pécs, Deindol; Pécs, Éger-v.; Pécs, Mecsekszentkút, Szunyola; Pécs, Remete-rét; Pécs, Tettye.

\section{Geometrinae}

Pseudoterpna pruinata (Hufnagel, 1767) - Cserkút, DK; Cserkút, Szentmiklós.

Geometra papilionaria (Linnaeus, 1758) - Abaliget, Nyáras-v.

Comibaena bajularia ([Denis \& Schiffermüller], 1775) (= pustulata) - Abaliget, Nyáras-v.; Bakonya, erdészház; Bakonya, Nagy-Rege; Cserkút, Cserkúti-dombok; Cserkút, Szentmiklós; Pécs, Deindol; Pécs, Tubes. 
Thetidia smaragdaria (Fabricius, 1787) (= Antonechloris s., Euchloris s.) - Abaliget, üdülők; Bakonya, erdészház; Bakonya, Nagy-Rege; Bükkösd, Szentdomján; Cserkút, Cserkúti-dombok; Cserkút, DK; Cserkút, Szentmiklós; Kővágószőlős, Kajdács-dülő; Pécs, Deindol; Pécs, Mecsekszentkút, Szunyola.

Hemistola chrysoprasaria (Esper, 1795) - Abaliget, Nyáras-v.; Abaliget, üdülők; Bakonya, erdészház; Bükkösd, Bükkösdi-v.; Cserkút, Cserkúti-dombok; Cserkút, DK; Cserkút, Szentmiklós; Hetvehely, Bükkösdi-v.; Kővágószőlős, Kajdács-dűlő; Mánfa, Nagy-Mély-v.; Pécs, Deindol; Pécs, Mecsekszentkút, Szunyola; Pécs, Tettye.

Jodis lactearia (Linnaeus, 1758) - Abaliget, Nyáras-v.; Abaliget, üdülők; Bakonya, erdészház; Bakonya, Nagy-Rege; Bakonya, Sás-v.; Bükkösd, Bükkösdi-v.; Hetvehely, Bükkösdi-v.; Kővágószőlős, Kajdács-dülő; Mánfa, Nagy-Mély-v.; Pécs, Mecsekszentkút, erdészház; Pécs, Tettye.

Thalera fimbrialis (Scopoli, 1763) - Abaliget, üdülők; Cserkút, Cserkúti-dombok; Cserkút, DK; Cserkút, Szentmiklós; Pécs, Deindol; Pécs, Mecsekszentkút, Szunyola.

Hemithea aestivaria (Hübner, 1789) - Abaliget, Nyáras-v.; Abaliget, üdülők; Bakonya, Nagy-Rege; Bükkösd, Bükkösdi-v.; Cserkút, Cserkúti-dombok; Cserkút, DK; Cserkút, Szentmiklós; Kővágószőlős, Kajdács-dűlő; Mánfa, Nagy-Mély-v.; Orfü, Cigány-h.; Pécs, Deindol; Pécs, Mecsekszentkút, Szunyola.

Chlorissa viridata (Linnaeus, 1758) - Abaliget, Nyáras-v.; Abaliget, üdülők; Bakonya, erdészház; Bakonya, Nagy-Rege; Bakonya, Sás-v.; Bükkösd, Bükkösdi-v.; Cserkút, Cserkúti-dombok; Cserkút, DK; Cserkút, Szentmiklós; Kővágószőlős, Kajdács-dűlő; Pécs, Deindol; Pécs, Mecsekszentkút, erdészház; Pécs, Mecsekszentkút, Szunyola; Pécs, Tettye.

Chlorissa cloraria (Hübner, 1813) - Abaliget, Nyáras-v.; Abaliget, üdülők; Cserkút, Cserkúti-dombok; Pécs, Árpád-tető; Pécs, Deindol.

Phaiogramma etruscaria (Zeller, 1849) (= Chlorissa pulmentaria) - Bakonya, Nagy-Rege; Pécs, Deindol; Pécs, Tettye; Pécs, Tubes.

\section{Sterrhinae}

Idaea serpentata (Hufnagel, 1767) $($ Idaea = Sterrha $)$ - Abaliget, Nyáras-v.; Abaliget, üdülök; Bakonya, erdészház; Bakonya, Nagy-Rege; Bükkösd, Bükkösdi-v.; Bükkösd, Szentdomján; Cserkút, Cserkúti-dombok; Cserkút, DK; Kővágószőlős, Petőc-akna.

Idaea muricata (Hufnagel, 1767) - Abaliget, Nyáras-v.; Abaliget, üdülők; Bakonya, Nagy-Rege; Bükkösd, Szentdomján; Cserkút, Cserkúti-dombok; Cserkút, DK; Cserkút, Szentmiklós; Kővágótöttös, Cserma-h.; Mánfa, Nagy-Mély-v.; Orfü, Cigány-h.; Pécs, Deindol.

Idaea rufaria (Hübner, 1799) - Kővágószőlős, Kajdács-dűlő; Pécs, Deindol; Pécs, Mecsekszentkút, Szunyola.

Idaea ochrata (Scopoli, 1763) - Bakonya, Nagy-Rege; Bakonya, Sás-v.; Cserkút, DK; Kővágószőlős, Kajdács-dülö; Pécs, Deindol; Pécs, Mecsekszentkút, Szunyola.

Idaea rusticata ([Denis \& Schiffermüller], 1775) - Abaliget, üdülök; Cserkút, Cserkúti-dombok; Cserkút, DK; Cserkút, Szentmiklós; Kővágószőlős, Kajdács-dűlő; Pécs, Deindol; Pécs, Mecsekszentkút, Szunyola; Pécs, Tettye.

Idaea filicata (Hübner, 1799) - Abaliget, Nyáras-v.; Bakonya, Nagy-Rege; Cserkút, Cserkúti-dombok; Cserkút, DK; Cserkút, Szentmiklós; Pécs, Deindol; Pécs, Mecsekszentkút, Szunyola; Pécs, Tettye.

Idaea moniliata ([Denis \& Schiffermüller], 1775) - Bakonya, Nagy-Rege; Bükkösd, Bükkösdi-v.; Cserkút, DK; Cserkút, Szentmiklós; Pécs, Mecsekszentkút, Szunyola; Pécs, Tettye.

Idaea obsoletaria rufularia (Herrich-Schäffer, 1845) - Cserkút, DK; Cserkút, Szentmiklós; Pécs, Tettye. Idaea inquinata (Scopoli, 1763) - Pécs, Deindol.

Idaea dilutaria (Hübner, 1799) - Cserkút, Cserkúti-dombok; Cserkút, DK; Mánfa, Nagy-Mély-v.; Pécs, Tettye.

Idaea fuscovenosa (Goeze, 1781) - Bakonya, Nagy-Rege; Bükkösd, Szentdomján; Cserkút, DK; Cserkút, Szentmiklós; Kővágószőlős, Kajdács-dűlő; Pécs, Tettye. 
Idaea humiliata (Hufnagel, 1767) - Bakonya, Nagy-Rege; Cserkút, Cserkúti-dombok; Cserkút, DK;

Cserkút, Szentmiklós; Kővágószőlős, Kajdács-dűlő; Kővágószőlős, Petőc-akna; Orfü, Cigány-h.; Pécs, Deindol; Pécs, Mecsekszentkút, Szunyola; Pécs, Tettye.

Idaea politaria (Hübner, 1799) - Abaliget, üdülők; Bakonya, Nagy-Rege; Cserkút, Cserkúti-dombok;

Kővágószőlős, Kajdács-dűlő; Mánfa, Nagy-Mély-v.; Pécs, Mecsekszentkút, Szunyola.

Idaea seriata (Schrank, 1802) (= virgularia (Hübner, 1799)) - Abaliget, üdülők; Cserkút, Szentmiklós;

Pécs, Deindol; Pécs, Tettye.

Idaea subsericeata (Haworth, 1809) - Abaliget, Nyáras-v.; Bakonya, erdészház; Bakonya, Nagy-Rege;

Cserkút, DK; Cserkút, Szentmiklós; Kővágószőlős, Kajdács-dűlő; Orfü, Cigány-h.; Pécs, Deindol; Pécs, Mecsekszentkút, Szunyola.

Idaea pallidata ([Denis \& Schiffermüller], 1775) - Pécs, Deindol.

Idaea dimidiata (Hufnagel, 1767) - Abaliget, üdülők; Bakonya, Nagy-Rege; Bakonya, Sás-v.; Cserkút, DK; Kővágótöttös, Cserma-h.; Mánfa, Nagy-Mély-v.; Orfü, Cigány-h.; Pécs, Deindol; Pécs, Tettye.

Idaea trigeminata (Haworth, 1809) - Abaliget, üdülők; Bakonya, Nagy-Rege; Bakonya, Sás-v.; Cserkút, DK; Cserkút, Szentmiklós; Mánfa, Nagy-Mély-v.; Pécs, Deindol; Pécs, Mecsekszentkút, Szunyola; Pécs, Tettye.

Idaea biselata (Hufnagel, 1767) - Abaliget, Nyáras-v.; Abaliget, üdülők; Bakonya, erdészház; Bakonya, Nagy-Rege; Bükkösd, Bükkösdi-v.; Cserkút, DK; Kővágószőlős, Kajdács-dűlő; Kővágótöttös, Cserma-h.; Mánfa, Nagy-Mély-v.; Orfü, Cigány-h.; Pécs, Deindol; Pécs, Mecsekszentkút, Szunyola.

Idaea emarginata (Linnaeus, 1758) - Abaliget, üdülők.

Idaea rubraria (Staudinger, 1901) - Cserkút, Cserkúti-dombok; Cserkút, DK; Cserkút, Szentmiklós; Pécs, Deindol.

Idaea aversata (Linnaeus, 1758) - Abaliget, Nyáras-v.; Abaliget, üdülők; Bakonya, erdészház; Bakonya, Nagy-Rege; Bakonya, Sás-v.; Bükkösd, Bükkösdi-v.; Bükkösd, Szentdomján; Cserkút, Cserkúti-dombok; Cserkút, DK; Cserkút, Szentmiklós; Hetvehely, Bükkösdi-v.; Kővágószőlős, Kajdács-dűlő; Kővágószőlős, Petőc-akna; Kővágótöttös, Cserma-h.; Mánfa, Nagy-Mély-v.; Orfü, Cigány-h.; Pécs, Deindol; Pécs, Mecsekszentkút, Szunyola; Pécs, Tettye; Pécs, Tubes.

Idaea degeneraria (Hübner, 1799) - Abaliget, üdülők; Bakonya, erdészház; Bakonya, Nagy-Rege; Cserkút, Cserkúti-dombok; Cserkút, DK; Cserkút, Szentmiklós; Hetvehely, Bükkösdi-v.; Kővágószőlős, Kajdács-dűlő; Mánfa, Nagy-Mély-v.; Orfü, Cigány-h.; Pécs, Deindol; Pécs, Mecsekszentkút, Szunyola; Pécs, Tettye.

Idaea straminata (Borkhausen, 1794) (= inornata) - Abaliget, üdülök; Bakonya, Nagy-Rege; Bükkösd,

Bükkösdi-v.; Cserkút, Cserkúti-dombok; Cserkút, DK; Kővágószőlős, Kajdács-dűlő; Mánfa, Nagy-Mély-v.; Pécs, Deindol.

Idaea deversaria (Herrich-Schäffer, 1847) - Abaliget, Nyáras-v.; Abaliget, üdülők; Bakonya, erdészház;

Bakonya, Nagy-Rege; Bükkösd, Szentdomján; Cserkút, Cserkúti-dombok; Kővágószőlős, Kajdács-dülő; Mánfa, Nagy-Mély-v.; Orfü, Cigány-h.; Pécs, Deindol; Pécs, Mecsekszentkút, Szunyola; Pécs, Tettye.

Scopula immorata (Linnaeus, 1758) - Abaliget, Nyáras-v.; Abaliget, üdülők; Bakonya, erdészház; Bakonya, Nagy-Rege; Bakonya, Sás-v.; Bükkösd, Bükkösdi-v.; Cserkút, Cserkúti-dombok; Cserkút, DK; Cserkút, Szentmiklós; Hetvehely, Bükkösdi-v.; Mánfa, Nagy-Mély-v.

Scopula caricaria (Reutti, 1853) - Abaliget, Nyáras-v.; Abaliget, üdülök; Hetvehely, Bükkösdi-v.

Scopula nigropunctata (Hufnagel, 1767) - Abaliget, Nyáras-v.; Bakonya, Nagy-Rege; Bükkösd, Szentdomján; Hetvehely, Bükkösdi-v.; Mánfa, Nagy-Mély-v.

Scopula virgulata ([Denis \& Schiffermüller], 1775) - Abaliget, üdülők; Bakonya, erdészház; Bakonya, Nagy-

Rege; Cserkút, Cserkúti-dombok; Cserkút, DK; Cserkút, Szentmiklós; Hetvehely, Bükkösdi-v.; Kővágószőlős, Kajdács-dűlő; Kővágótöttös, Cserma-h.; Mánfa, Nagy-Mély-v.; Pécs, Deindol; Pécs, Mecsekszentkút, Szunyola; Pécs, Tubes.

Scopula ornata (Scopoli, 1763) - Bakonya, erdészház; Bakonya, Nagy-Rege; Cserkút, Cserkúti-dombok; Cserkút, DK; Pécs, Éger-v.

Scopula rubiginata (Hufnagel, 1767) - Bakonya, erdészház; Cserkút, Szentmiklós; Kővágószőlős, Kajdácsdülö; Mánfa, Nagy-Mély-v.; Pécs, Deindol; Pécs, Mecsekszentkút, Szunyola. 
Scopula incanata (Linnaeus, 1758) - Cserkút, Cserkúti-dombok.

Scopula marginepunctata (Goeze, 1781) - Abaliget, üdülők; Bakonya, erdészház; Cserkút, Cserkútidombok; Cserkút, DK; Cserkút, Szentmiklós; Kővágószőlős, Kajdács-dűlő; Kővágószőlős, Petőc-akna; Pécs, Deindol; Pécs, Éger-v.; Pécs, Tettye; Pécs, Tubes.

Scopula immutata (Linnaeus, 1758) - Abaliget, üdülők; Bükkösd, Bükkösdi-v.; Cserkút, Cserkúti-dombok; Cserkút, DK; Cserkút, Szentmiklós; Mánfa, Nagy-Mély-v..

Scopula floslactata (Haworth, 1809) (= S. lactata) - Abaliget, Nyáras-v.; Cserkút, Szentmiklós; Hetvehely, Bükkösdi-v.; Mánfa, Nagy-Mély-v.

Scopula subpunctaria (Herrich-Schäffer, 1847) - Pécs, Tettye.

Scopula flaccidaria (Zeller, 1852) - Abaliget, üdülök; Bükkösd, Szentdomján.

Rhodostrophia vibicaria (Clerck, 1759) - Bakonya, erdészház; Bakonya, Nagy-Rege; Cserkút, Cserkútidombok; Hetvehely, Bükkösdi-v.; Kővágószőlös, Kajdács-dủlő; Kővágótöttös, Cserma-h.; Mánfa, NagyMély-v.; Pécs, Deindol; Pécs, Éger-v.; Pécs, Mecsekszentkút, erdészház; Pécs, Mecsekszentkút, Szunyola; Pécs, Tettye; Pécs, Tubes.

Timandra comae Schmidt, 1931 (= T. griseata, Calothysanis amata) - Abaliget, Nyáras-v.; Abaliget, üdülők; Bakonya, erdészház; Bakonya, Nagy-Rege; Bükkösd, Bükkösdi-v.; Bükkösd, Szentdomján; Cserkút, Cserkúti-dombok; Cserkút, DK; Cserkút, Szentmiklós; Hetvehely, Bükkösdi-v.; Kővágószőlös, Kajdács-dűlő; Kővágószőlős, Petőc-akna; Kővágótöttös, Cserma-h.; Mánfa, Nagy-Mély-v.; Orfü, Cigány-h.; Pécs, Deindol; Pécs, Mecsekszentkút, erdészház; Pécs, Mecsekszentkút, Szunyola; Pécs, Tettye; Pécs, Tubes.

Cyclophora pendularia (Clerck, 1759) (= orbicularia) - Cserkút, DK; Pécs, Deindol.

Cyclophora albiocellaria (Hübner, 1789) - Bakonya, erdészház; Cserkút, DK; Cserkút, Szentmiklós; Pécs, Deindol; Pécs, Éger-v.

Cyclophora annularia (Fabricius, 1775) (= annulata (Fabricius, 1775)) - Abaliget, Nyáras-v.; Abaliget, üdülők; Bakonya, erdészház; Bakonya, Nagy-Rege; Bakonya, Sás-v.; Cserkút, Cserkúti-dombok; Cserkút, DK; Cserkút, Szentmiklós; Hetvehely, Bükkösdi-v.; Kővágószőlős, Kajdács-dűlő; Kővágószőlős, Petőc-akna; Mánfa, Nagy-Mély-v.; Orfü, Cigány-h.; Pécs, Deindol; Pécs, Mecsekszentkút, erdészház; Pécs, Mecsekszentkút, Szunyola; Pécs, Tettye; Pécs, Tubes.

Cyclophora quercimontaria (Bastelberger, 1897) - Bakonya, erdészház; Bakonya, Nagy-Rege; Kővágószőlős, Petőc-akna; Orfü, Cigány-h.; Pécs, Deindol; Pécs, Mecsekszentkút, Szunyola.

Cyclophora ruficiliaria (Herrich-Schäffer, 1855) - Abaliget, Nyáras-v.; Bakonya, erdészház; Bakonya, Nagy-Rege; Bakonya, Sás-v.; Bükkösd, Szentdomján; Cserkút, Cserkúti-dombok; Cserkút, DK; Cserkút, Szentmiklós; Mánfa, Nagy-Mély-v.; Orfü, Cigány-h.; Pécs, Deindol; Pécs, Mecsekszentkút, erdészház.

Cyclophora porata (Linnaeus, 1767) - Abaliget, Nyáras-v.; Bakonya, erdészház; Bakonya, Nagy-Rege; Cserkút, Cserkúti-dombok; Cserkút, DK; Cserkút, Szentmiklós; Kővágószőlős, Kajdács-dülő; Kővágószőlős, Petőc-akna; Kővágótöttös, Cserma-h.; Pécs, Deindol.

Cyclophora punctaria (Linnaeus, 1758) - Abaliget, Nyáras-v.; Bakonya, erdészház; Bakonya, Nagy-Rege; Bükkösd, Bükkösdi-v.; Cserkút, Cserkúti-dombok; Cserkút, DK; Cserkút, Szentmiklós; Hetvehely, Bükkösdi-v.; Kővágószőlős, Petőc-akna; Kővágótöttös, Cserma-h.; Mánfa, Nagy-Mély-v.; Orfü, Cigány-h.; Pécs, Deindol; Pécs, Mecsekszentkút, erdészház; Pécs, Mecsekszentkút, Szunyola; Pécs, Tettye.

Cyclophora linearia (Hübner, 1799) - Abaliget, Nyáras-v.; Bakonya, erdészház; Bakonya, Nagy-Rege; Bakonya, Sás-v.; Cserkút, Cserkúti-dombok; Cserkút, DK; Kővágószőlős, Petőc-akna; Kővágótöttös, Cserma-h.; Mánfa, Nagy-Mély-v.; Orfü, Cigány-h.; Pécs, Deindol; Pécs, Éger-v.; Pécs, Mecsekszentkút, erdészház; Pécs, Mecsekszentkút, Szunyola; Pécs, Tubes.

Rhodometra sacraria (Linnaeus, 1767) - Pécs, Deindol.

\section{Larentiinae}

Lythria purpuraria (Linnaeus, 1758) - Abaliget, üdülők; Bakonya, erdészház; Bakonya, Nagy-Rege; Bükkösd, Bükkösdi-v.; Bükkösd, Szentdomján; Cserkút, Cserkúti-dombok; Kővágószőlős, Kajdács-dülö; Pécs, Mecsekszentkút, Szunyola.

Lythria cruentaria (Hufnagel, 1767) (= L. purpurata) - Cserkút, DK; Pécs, Deindol. 
Phibalapteryx virgata (Hufnagel, 1767) - Kővágószőlős, Kajdács-dűlő.

Scotopteryx chenopodiata (Linnaeus, 1758) - Abaliget, üdülők.

Scotopteryx moeniata (Scopoli, 1763) - Cserkút, DK; Cserkút, Szentmiklós; Pécs, Deindol.

Scotopteryx luridata (Hufnagel, 1767) (= Ortholita plumbaria) - Abaliget, Nyáras-v.; Abaliget, üdülök;

Bakonya, erdészház; Bakonya, Nagy-Rege; Bükkösd, Bükkösdi-v.; Cserkút, Cserkúti-dombok; Cserkút, DK; Cserkút, Szentmiklós; Kővágószőlős, Kajdács-dűlő; Kővágótöttös, Cserma-h.; Pécs, Deindol; Pécs, Éger-v.; Pécs, Mecsekszentkút, Szunyola; Pécs, Tubes.

Orthonama vittata (Borkhausen, 1794) (= O. lignata) - Cserkút, Cserkúti-dombok; Cserkút, DK; Cserkút, Szentmiklós.

Orthonama obstipata (Fabricius, 1794) (= Nycterosea o.) - Cserkút, DK; Pécs, Deindol.

Xanthorhoe biriviata (Borkhausen, 1794) - Cserkút, DK; Cserkút, Szentmiklós; Mánfa, Nagy-Mély-v.

Xanthorhoe designata (Hufnagel, 1767) - Abaliget, Nyáras-v.; Bakonya, Sás-v.; Mánfa, Nagy-Mély-v.

Xanthorhoe spadicearia ([Denis \& Schiffermüller], 1775) - Abaliget, üdülők; Pécs, Mecsekszentkút, erdészház.

Xanthorhoe ferrugata (Clerck, 1759) - Abaliget, Nyáras-v.; Abaliget, üdülők; Bakonya, erdészház; Bükkösd, Bükkösdi-v.; Bükkösd, Szentdomján; Cserkút, Cserkúti-dombok; Cserkút, DK; Cserkút, Szentmiklós; Mánfa, Nagy-Mély-v.; Orfü, Cigány-h.; Pécs, Deindol; Pécs, Mecsekszentkút, erdészház.

Xanthorhoe quadrifasciata (Clerck, 1759) - Abaliget, üdülők; Bakonya, Sás-v.; Pécs, Mecsekszentkút, Szunyola.

Xanthorhoe fluctuata (Linnaeus, 1758) - Abaliget, Nyáras-v.; Abaliget, üdülök; Bakonya, erdészház; Bükkösd, Bükkösdi-v.; Bükkösd, Szentdomján; Cserkút, Cserkúti-dombok; Cserkút, DK; Cserkút, Szentmiklós; Hetvehely, Bükkösdi-v.; Kővágószőlős, Kajdács-dűlő; Kővágószőlős, Petőc-akna; Mánfa, Nagy-Mély-v.; Orfü, Cigány-h.; Pécs, Deindol; Pécs, Éger-v.; Pécs, Mecsekszentkút, erdészház; Pécs, Mecsekszentkút, Szunyola; Pécs, Tettye.

Catarhoe rubidata ([Denis \& Schiffermüller], 1775) (=Euphya $r$.) - Abaliget, üdülök; Bakonya, erdészház; Bakonya, Nagy-Rege; Cserkút, DK; Kővágószőlős, Petőc-akna; Mánfa, Nagy-Mély-v.; Orfü, Cigány-h.; Pécs, Deindol; Pécs, Tettye; Pécs, Tubes.

Catarhoe cuculata (Hufnagel, 1767) (= Euphya c.) - Abaliget, üdülők; Bakonya, erdészház; Bakonya, Nagy-Rege; Bükkösd, Szentdomján; Cserkút, Cserkúti-dombok; Cserkút, DK; Cserkút, Szentmiklós; Mánfa, Nagy-Mély-v.; Orfü, Cigány-h.

Epirrhoe tristata (Linnaeus, 1758) - Abaliget, üdülők; Bükkösd, Szentdomján; Cserkút, DK; Cserkút, Szentmiklós; Mánfa, Nagy-Mély-v.; Pécs, Deindol.

Epirrhoe alternata (Müller, 1764) - Abaliget, Nyáras-v.; Abaliget, üdülők; Bakonya, erdészház; Bakonya, Nagy-Rege; Bükkösd, Bükkösdi-v.; Bükkösd, Szentdomján; Cserkút, Cserkúti-dombok; Cserkút, DK; Cserkút, Szentmiklós; Hetvehely, Bükkösdi-v.; Kővágószőlős, Kajdács-dülő; Kővágótöttös, Cserma-h.; Mánfa, NagyMély-v.; Orfü, Cigány-h.; Pécs, Deindol; Pécs, Mecsekszentkút, erdészház; Pécs, Mecsekszentkút, Szunyola; Pécs, Tettye; Pécs, Tubes.

Epirrhoe rivata (Hübner, 1813) - Abaliget, üdülők; Bakonya, Nagy-Rege; Cserkút, Cserkúti-dombok; Kővágószőlős, Kajdács-dülő; Mánfa, Nagy-Mély-v.; Pécs, Deindol; Pécs, Mecsekszentkút, Szunyola; Pécs, Tubes.

Epirrhoe galiata ([Denis \& Schiffermüller], 1775) - Abaliget, üdülök; Bakonya, erdészház; Bükkösd, Bükkösdi-v.; Cserkút, DK; Cserkút, Szentmiklós; Mánfa, Nagy-Mély-v.; Pécs, Deindol; Pécs, Mecsekszentkút, erdészház; Pécs, Mecsekszentkút, Szunyola; Pécs, Tettye; Pécs, Tubes.

Euphya biangulata (Haworth, 1809) (=E. picata) - Abaliget, Nyáras-v.; Abaliget, üdülők; Bakonya, erdészház; Bakonya, Nagy-Rege; Bükkösd, Szentdomján; Cserkút, Cserkúti-dombok; Mánfa, Nagy-Mély-v.; Orfü, Cigány-h.; Pécs, Deindol; Pécs, Mecsekszentkút, erdészház; Pécs, Mecsekszentkút, Szunyola; Pécs, Tubes.

Costaconvexa polygrammata (Borkhausen, 1794) (= Euphya p.) - Bükkösd, Szentdomján; Cserkút, Cserkúti-dombok; Cserkút, DK; Kővágószőlős, Kajdács-dűlő; Pécs, Deindol; Pécs, Mecsekszentkút, Szunyola. 
Camptogramma bilineata (Linnaeus, 1758) (=Euphya b.) - Abaliget, Nyáras-v.; Abaliget, üdülők; Bakonya, erdészház; Bakonya, Nagy-Rege; Cserkút, Cserkúti-dombok; Cserkút, DK; Cserkút, Szentmiklós; Hetvehely, Bükkösdi-v.; Kővágószőlős, Kajdács-dűlő; Kővágótöttös, Cserma-h.; Mánfa, Nagy-Mély-v.; Pécs, Deindol; Pécs, Mecsekszentkút, Szunyola; Pécs, Tettye.

Entephria caesiata ([Denis \& Schiffermüller], 1775) - Mánfa, Nagy-Mély-v.

Anticlea badiata ([Denis \& Schiffermüller], 1775) (= Earophila b.) - Abaliget, Nyáras-v.; Bakonya, erdészház; Bükkösd, Bükkösdi-v.; Cserkút, Cserkúti-dombok; Cserkút, DK; Cserkút, vízmü környék; Kővágószőlős, Kajdács-dűlő; Kővágótöttös, Bicsérdi-vízf.; Mánfa, Nagy-Mély-v.; Orfü, Cigány-h.; Pécs, Árpád-tető; Pécs, Deindol; Pécs, Mecsekszentkút, erdészház; Pécs, Mecsekszentkút, Szunyola; Pécs, Tettye.

Anticlea derivata ([Denis \& Schiffermüller], 1775) (= Coenotephria d.) - Abaliget, Nyáras-v.; Cserkút, Cserkúti-dombok; Cserkút, DK; Hetvehely, Bükkösdi-v.; Kővágószőlős, Kajdács-dűlő; Mánfa, Nagy-Mély-v.; Pécs, Deindol; Pécs, Éger-v.; Pécs, Mecsekszentkút, Szunyola.

Mesoleuca albicillata (Linnaeus, 1758) - Abaliget, Nyáras-v.; Abaliget, üdülők; Bükkösd, Szentdomján; Mánfa, Nagy-Mély-v.; Orfü, Cigány-h.

Pelurga comitata (Linnaeus, 1758) - Abaliget, üdülők; Cserkút, DK; Pécs, Deindol; Pécs, Tettye.

Lampropteryx suffumata ([Denis \& Schiffermüller], 1775) - Bükkösd, Bükkösdi-v.; Mánfa, Nagy-Mély-v.; Orfü, Cigány-h.

Cosmorhoe ocellata (Linnaeus, 1758) (= Lampropteryx o.) - Abaliget, üdülők; Bakonya, erdészház; Bükkösd, Bükkösdi-v.; Cserkút, Cserkúti-dombok; Cserkút, DK; Cserkút, Szentmiklós; Kővágószőlős, Kajdács-dűlő; Kővágótöttös, Cserma-h.; Mánfa, Nagy-Mély-v.; Pécs, Deindol; Pécs, Mecsekszentkút, Szunyola; Pécs, Tettye.

Eulithis mellinata (Fabricius, 1787) (= Lygris m.) - Abaliget, üdülök; Cserkút, DK; Mánfa, Nagy-Mély-v.; Pécs, Deindol.

Eulithis pyraliata ([Denis \& Schiffermüller], 1775) (= Lygris p.) - Abaliget, Nyáras-v.; Abaliget, üdülök; Bakonya, erdészház; Bakonya, Nagy-Rege; Bükkösd, Bükkösdi-v.; Cserkút, Cserkúti-dombok; Mánfa, NagyMély-v.; Orfü, Cigány-h.; Pécs, Deindol; Pécs, Mecsekszentkút, Szunyola.

Ecliptopera silaceata ([Denis \& Schiffermüller], 1775) - Abaliget, Nyáras-v.; Abaliget, üdülők; Mánfa, Nagy-Mély-v.; Orfü, Cigány-h.; Pécs, Deindol.

Chloroclysta siterata (Hufnagel, 1767) - Kővágószőlős, Kajdács-dűlő; Kővágószőlős, Petőc-akna; Pécs, Deindol.

Cidaria fulvata (Forster, 1771) - Abaliget, üdülők; Bakonya, erdészház; Bükkösd, Bükkösdi-v.; Cserkút, DK; Cserkút, Szentmiklós; Hetvehely, Bükkösdi-v.; Pécs, Mecsekszentkút, Szunyola; Pécs, Deindol; Pécs, Tettye.

Thera obeliscata (Hübner, 1787) - Pécs, Deindol.

Thera variata ([Denis \& Schiffermüller], 1775) - Abaliget, üdülők; Pécs, Deindol; Pécs, Mecsekszentkút, Szunyola.

Electrophaes corylata (Thunberg, 1792) - Abaliget, Nyáras-v.; Abaliget, üdülők; Bakonya, erdészház; Cserkút, Szentmiklós; Hetvehely, Bükkösdi-v.; Mánfa, Nagy-Mély-v.; Pécs, Tubes.

Colostygia pectinataria (Knoch, 1781) - Abaliget, Nyáras-v.; Abaliget, üdülök; Bakonya, erdészház; Bakonya, Nagy-Rege; Bükkösd, Szentdomján; Cserkút, Cserkúti-dombok; Hetvehely, Bükkösdi-v.; Kővágótöttös, Cserma-h.; Mánfa, Nagy-Mély-v.; Orfü, Cigány-h.; Pécs, Deindol; Pécs, Éger-v.; Pécs, Mecsekszentkút, Szunyola; Pécs, Tubes.

Hydriomena impluviata ([Denis \& Schiffermüller], 1775) (= H. coerulata) - Abaliget, Nyáras-v.; Abaliget, üdülők; Bükkösd, Bükkösdi-v.; Cserkút, Szentmiklós; Hetvehely, Bükkösdi-v.; Mánfa, Nagy-Mély-v.

Horisme vitalbata ([Denis \& Schiffermüller], 1775) - Abaliget, üdülők; Bükkösd, Bükkösdi-v.; Hetvehely, Bükkösdi-v.; Kővágótöttös, Cserma-h.; Pécs, Deindol; Pécs, Mecsekszentkút, erdészház; Pécs, Mecsekszentkút, Szunyola; Pécs, Tettye.

Horisme tersata ([Denis \& Schiffermüller], 1775) - Abaliget, Nyáras-v.; Abaliget, üdülők; Bakonya, erdészház; Bakonya, Nagy-Rege; Bakonya, Sás-v.; Bükkösd, Bükkösdi-v.; Bükkösd, Szentdomján; Cserkút, Cserkúti-dombok; Cserkút, DK; Cserkút, Szentmiklós; Hetvehely, Bükkösdi-v.; Kővágószőlős, Kajdács-dülő; 
Kővágószőlős, Petőc-akna; Kővágótöttös, Cserma-h.; Mánfa, Nagy-Mély-v.; Orfü, Cigány-h.; Pécs, Deindol; Pécs, Mecsekszentkút, Szunyola; Pécs, Tettye; Pécs, Tubes.

Horisme corticata (Treitschke, 1835) - Abaliget, Nyáras-v.; Abaliget, üdülők; Cserkút, DK; Cserkút, Szentmiklós; Hetvehely, Bükkösdi-v.; Kővágószőlős, Kajdács-dűlő; Mánfa, Nagy-Mély-v.; Pécs, Deindol; Pécs, Mecsekszentkút, Szunyola; Pécs, Tettye.

Melanthia procellata ([Denis \& Schiffermüller], 1775) - Abaliget, Nyáras-v.; Abaliget, üdülök; Bakonya, erdészház; Bakonya, Sás-v.; Cserkút, Cserkúti-dombok; Cserkút, DK; Hetvehely, Bükkösdi-v.; Mánfa, NagyMély-v.; Pécs, Deindol; Pécs, Mecsekszentkút, erdészház; Pécs, Tettye.

Anticollix sparsata (Treitschke, 1828) - Abaliget, Nyáras-v.; Abaliget, üdülök; Bakonya, Sás-v.; Bükkösd, Szentdomján; Pécs, Mecsekszentkút, erdészház; Mánfa, Nagy-Mély-v.

Triphosa dubitata (Linnaeus, 1758) - Abaliget, üdülők; Kővágószőlős, Kajdács-dűlő; Mánfa, NagyMély-v.; Pécs, Éger-v.; Pécs, Mecsekszentkút, Szunyola.

Philereme vetulata ([Denis \& Schiffermüller], 1775) - Bükkösd, Bükkösdi-v.; Pécs, Tettye; Pécs, Tubes.

Philereme transversata (Hufnagel, 1767) - Abaliget, üdülök; Bükkösd, Szentdomján; Cserkút, DK; Cserkút, Szentmiklós; Kővágószőlős, Kajdács-dűlő; Mánfa, Nagy-Mély-v.; Pécs, Tettye.

Epirrita dilutata ([Denis \& Schiffermüller], 1775) (=Oporinia d.) - Bakonya, erdészház; Cserkút, DK; Cserkút, Szentmiklós; Cserkút, vízmű környék; Kővágószőlős, Kajdács-dűlő; Kővágószőlős, Petőc-akna; Kővágótöttös, Cserma-h.; Mánfa, Nagy-Mély-v.; Orfü, Cigány-h.; Pécs, Deindol; Pécs, Éger-v.; Pécs, Remeterét; Pécs, Tettye.

Epirrita christyi (Allen, 1906) (= Oporinia ch.) - Bakonya, erdészház; Mánfa, Nagy-Mély-v.; Pécs, Éger-v.

Operophtera brumata (Linnaeus, 1758) - Abaliget, üdülők; Bakonya, erdészház; Cserkút, DK; Cserkút, Szentmiklós; Mánfa, Nagy-Mély-v.; Orfü, Cigány-h.; Pécs, Deindol; Pécs, Éger-v.; Pécs, Mecsekszentkút, Szunyola; Pécs, Remete-rét; Pécs, Tettye.

Operophtera fagata (Scharfenberg, 1805) - Bakonya, erdészház; Mánfa, Nagy-Mély-v.

Mesotype parallelolineata (Retzius, 1783) (= Perizoma p.) - Mánfa, Nagy-Mély-v.

Perizoma alchemillata (Linnaeus, 1758) - Abaliget, üdülök; Bükkösd, Szentdomján; Cserkút, Cserkútidombok; Cserkút, DK; Cserkút, Szentmiklós; Mánfa, Nagy-Mély-v.; Pécs, Deindol.

Perizoma hydrata (Treitschke, 1829) - Cserkút, DK; Mánfa, Nagy-Mély-v.; Pécs, Mecsekszentkút, Szunyola.

Perizoma lugdunaria (Herrich-Schäffer, 1855) - Abaliget, üdülők; Bakonya, Sás-v.; Cserkút, DK; Cserkút, Szentmiklós; Mánfa, Nagy-Mély-v.; Pécs, Deindol.

Perizoma bifaciata (Haworth, 1809) - Bakonya, erdészház; Kővágószőlős, Kajdács-dűlő; Pécs, Deindol.

Gymnoscelis rufifasciata (Haworth, 1809) (= pumilata) - Abaliget, üdülők; Bakonya, Nagy-Rege; Bakonya,

Sás-v.; Cserkút, Cserkúti-dombok; Cserkút, DK; Kővágószőlős, Kajdács-dűlő; Kővágószőlős, Petőc-akna; Kővágótöttös, Cserma-h.; Mánfa, Nagy-Mély-v.; Orfü, Cigány-h.; Pécs, Árpád-tető; Pécs, Deindol; Pécs, Mecsekszentkút, Szunyola; Pécs, Tettye.

Chloroclystis v-ata (Haworth, 1809) (= coronata) - Abaliget, Nyáras-v.; Bakonya, Nagy-Rege; Bakonya, Sás-v.; Bükkösd, Szentdomján; Cserkút, Cserkúti-dombok; Cserkút, DK; Cserkút, Szentmiklós; Kővágószőlős, Kajdács-dűlő; Kővágószőlős, Petőc-akna; Mánfa, Nagy-Mély-v.; Orfü, Cigány-h.; Pécs, Deindol; Pécs, Mecsekszentkút, erdészház; Pécs, Mecsekszentkút, Szunyola; Pécs, Tettye.

Pasiphila chloerata (Mabille, 1870) (= Chloroclystis ch.) - Pécs, Deindol.

Pasiphila rectangulata (Linnaeus, 1758) (= Chloroclystis r., Rhinoprora r.) - Abaliget, Nyáras-v.; Bakonya, Nagy-Rege; Cserkút, Cserkúti-dombok; Cserkút, DK; Mánfa, Nagy-Mély-v.; Pécs, Deindol; Pécs, Tettye.

Eupithecia haworthiata Doubleday, 1856 - Abaliget, Nyáras-v.; Bakonya, erdészház; Bükkösd, Bükkösdi-v.; Cserkút, Cserkúti-dombok; Cserkút, DK; Hetvehely, Bükkösdi-v.; Mánfa, Nagy-Mély-v.; Pécs, Deindol; Pécs, Tettye; Pécs, Tubes.

Eupithecia inturbata (Hübner, 1817) - Mánfa, Nagy-Mély-v.

Eupithecia linariata ([Denis \& Schiffermüller], 1775) - Bakonya, erdészház; Cserkút, DK; Cserkút, Szentmiklós; Hetvehely, Bükkösdi-v.; Kővágószőlős, Kajdács-dülő; Pécs, Deindol; Pécs, Tettye. 
Eupithecia pyreneata Mabille, 1871 (= pulchellata ) - Abaliget, üdülök; Pécs, Deindol.

Eupithecia laquaearia Herrich-Schäffer, 1848 - Mánfa, Nagy-Mély-v..

Eupithecia plumbeolata (Haworth, 1809) - Abaliget, Nyáras-v.; Bakonya, erdészház; Bakonya, Nagy-Rege; Cserkút, Cserkúti-dombok; Cserkút, Szentmiklós; Kővágószőlős, Kajdács-dűlő; Mánfa, Nagy-Mély-v.; Orfü, Cigány-h.; Pécs, Deindol; Pécs, Mecsekszentkút, Szunyola; Pécs, Tettye.

Eupithecia pygmaeata (Hübner, 1799) - Mánfa, Nagy-Mély-v.; Pécs, Deindol.

Eupithecia venosata (Fabricius, 1787) - Pécs, Mecsekszentkút, Szunyola; Pécs, Tubes.

Eupithecia silenicolata Mabille, 1867 - Abaliget, üdülők; Bakonya, Nagy-Rege; Mánfa, Nagy-Mély-v.; Pécs, Deindol; Pécs, Mecsekszentkút, Szunyola.

Eupithecia abbreviata Stephens, 1831 - Abaliget, Nyáras-v.; Abaliget, üdülök; Bakonya, erdészház; Bükkösd, Szentdomján; Cserkút, Cserkúti-dombok; Cserkút, DK; Hetvehely, Bükkösdi-v.; Kővágószőlős, Kajdács-dűlő; Mánfa, Nagy-Mély-v.; Pécs, Deindol; Pécs, Mecsekszentkút, erdészház; Pécs, Mecsekszentkút, Szunyola; Pécs, Tettye.

Eupithecia dodoneata Guenée, 1857 - Bakonya, erdészház; Cserkút, DK; Mánfa, Nagy-Mély-v.; Pécs, Deindol; Pécs, Mecsekszentkút, erdészház; Pécs, Mecsekszentkút, Szunyola; Pécs, Tettye.

Eupithecia pusillata ([Denis \& Schiffermüller], 1775) (= sobrinata) - Bakonya, erdészház; Cserkút, Cserkúti-dombok; Cserkút, DK; Cserkút, Szentmiklós; Pécs, Deindol; Pécs, Éger-v.

Eupithecia tripunctaria Herrich-Schäffer, 1852 - Hetvehely, Bükkösdi-v.; Mánfa, Nagy-Mély-v.

Eupithecia virgaureata Doubleday, 1861 - Cserkút, DK; Cserkút, Szentmiklós; Mánfa, Nagy-Mély-v.; Pécs, Mecsekszentkút, erdészház.

Eupithecia lariciata (Freyer, 1841) - Mánfa, Nagy-Mély-v.; Pécs, Tettye.

Eupithecia lanceata (Hübner, 1825) - Pécs, Mecsekszentkút, Szunyola.

Eupithecia selinata Herrich-Schäffer, 1861 - Abaliget, Nyáras-v.; Bakonya, erdészház; Mánfa, NagyMély-v.

Eupithecia pimpinellata (Hübner, 1813) - Bakonya, Nagy-Rege; Kővágószőlős, Petőc-akna.

Eupithecia innotata (Hufnagel, 1767) - Bakonya, erdészház; Cserkút, Cserkúti-dombok; Cserkút, DK; Cserkút, Szentmiklós; Mánfa, Nagy-Mély-v.; Pécs, Deindol; Pécs, Tettye.

Eupithecia indigata (Hübner, 1813) - Pécs, Tettye.

Eupithecia centaureata ([Denis \& Schiffermüller], 1775) - Bakonya, erdészház; Cserkút, DK; Pécs, Deindol.

Eupithecia insigniata (Hübner, 1790) - Cserkút, Cserkúti-dombok; Cserkút, DK; Kővágószőlős, Kajdácsdülő; Kővágótöttös, Bicsérdi-vízf.; Pécs, Deindol; Pécs, Mecsekszentkút, Szunyola.

Eupithecia trisignaria Herrich-Schäffer, 1848 - Abaliget, Nyáras-v.

Eupithecia absinthiata (Clerck, 1759) - Cserkút, DK; Mánfa, Nagy-Mély-v.

Eupithecia assimilata Doubleday, 1856 - Abaliget, Nyáras-v.; Abaliget, üdülök; Bükkösd, Bükkösdi-v.; Bükkösd, Szentdomján; Cserkút, Cserkúti-dombok; Pécs, Mecsekszentkút, erdészház; Mánfa, Nagy-Mély-v.

Eupithecia denotata (Hübner, 1813) - Mánfa, Nagy-Mély-v.

Eupithecia millefoliata Rössler, 1866 - Cserkút, DK; Mánfa, Nagy-Mély-v.; Pécs, Deindol; Pécs, Tettye; Pécs, Tubes.

Eupithecia icterata (Villers, 1789) - Abaliget, Nyáras-v.; Abaliget, üdülők; Bakonya, erdészház; Cserkút, Cserkúti-dombok; Cserkút, DK; Cserkút, Szentmiklós; Mánfa, Nagy-Mély-v.; Pécs, Deindol; Pécs, Mecsekszentkút, Szunyola.

Eupithecia succenturiata (Linnaeus, 1758) - Cserkút, Szentmiklós; Pécs, Deindol.

Eupithecia subfuscata (Haworth, 1809) (= castigata Hübner, 1813) - Bakonya, erdészház; Bükkösd, Bükkösdi-v.; Cserkút, DK; Cserkút, Szentmiklós; Mánfa, Nagy-Mély-v.; Pécs, Deindol.

Chesias rufata (Fabricius, 1775) - Cserkút, DK.

Aplocera plagiata (Linnaeus, 1758) (= Anaitis p.) - Abaliget, üdülök; Bakonya, erdészház; Cserkút, Cserkúti-dombok; Cserkút, DK; Cserkút, Szentmiklós; Pécs, Deindol; Pécs, Mecsekszentkút, Szunyola; Pécs, Tettye; Pécs, Tubes. 
Aplocera efformata (Guenée, 1857) (= Anaitis e.) - Bakonya, Nagy-Rege; Cserkút, DK; Cserkút, Szentmiklós; Kővágószőlős, Kajdács-dülő; Mánfa, Nagy-Mély-v.; Pécs, Deindol.

Lithostege griseata ([Denis \& Schiffermüller], 1775) - Abaliget, Nyáras-v.

Euchoeca nebulata (Scopoli, 1763) - Abaliget, Nyáras-v.; Bakonya, Nagy-Rege; Mánfa, Nagy-Mély-v.; Pécs, Deindol.

Asthena albulata (Hufnagel, 1767) - Abaliget, Nyáras-v.; Abaliget, üdülők; Bakonya, erdészház; Bakonya, Nagy-Rege; Bakonya, Sás-v.; Bükkösd, Bükkösdi-v.; Bükkösd, Szentdomján; Cserkút, Cserkúti-dombok; Cserkút, DK; Cserkút, Szentmiklós; Hetvehely, Bükkösdi-v.; Mánfa, Nagy-Mély-v.; Orfü, Cigány-h.; Pécs, Deindol; Pécs, Mecsekszentkút, erdészház; Pécs, Tettye; Pécs, Tubes.

Asthena anseraria (Herrich-Schäffer, 1855) - Bükkösd, Bükkösdi-v.; Mánfa, Nagy-Mély-v.

Hydrelia flammeolaria (Hufnagel, 1767) - Abaliget, üdülők; Bakonya, Nagy-Rege; Cserkút, DK; Cserkút, Szentmiklós; Hetvehely, Bükkösdi-v.; Mánfa, Nagy-Mély-v.; Orfü, Cigány-h.; Pécs, Deindol; Pécs, Tettye; Pécs, Tubes.

Minoa murinata (Scopoli, 1763) - Bakonya, erdészház; Bakonya, Nagy-Rege; Bakonya, Sás-v.; Bükkösd, Bükkösdi-v.; Bükkösd, Szentdomján; Cserkút, Cserkúti-dombok; Cserkút, DK; Cserkút, Szentmiklós; Hetvehely, Bükkösdi-v.; Kővágószőlős, Kajdács-dűlő; Kővágótöttös, Cserma-h.; Mánfa, Nagy-Mély-v.; Pécs, Árpád-tető; Pécs, Deindol; Pécs, Éger-v.; Pécs, Tubes.

Lobophora halterata (Hufnagel, 1767) - Bakonya, erdészház; Orfü, Cigány-h.; Pécs, Deindol; Pécs, Mecsekszentkút, Szunyola.

Trichopteryx polycommata ([Denis \& Schiffermüller], 1775) (= Nothopteryx p.) - Bükkösd, Bükkösdi-v.

Trichopteryx carpinata (Borkhausen, 1794) (= Nothopteryx c.) - Bükkösd, Bükkösdi-v.; Kővágószölős, Petöc-akna.

Pterapherapteryx sexalata (Retzius, 1783) (= Mysticoptera s.)- Bükkösd, Bükkösdi-v.; Bükkösd, Szentdomján; Hetvehely, Bükkösdi-v.

Acasis viretata (Hübner, 1799) (= Trichopteryx v.) - Cserkút, Szentmiklós; Mánfa, Nagy-Mély-v.

\section{Ennominae}

Abraxas grossulariata (Linnaeus, 1758) - Abaliget, Nyáras-v.; Cserkút, Cserkúti-dombok; Cserkút, DK; Cserkút, Szentmiklós; Mánfa, Nagy-Mély-v.; Pécs, Tettye; Pécs, Tubes.

Lomaspilis marginata (Linnaeus, 1758) - Abaliget, Nyáras-v.; Abaliget, üdülők; Bakonya, erdészház; Bakonya, Nagy-Rege; Bükkösd, Bükkösdi-v.; Bükkösd, Szentdomján; Cserkút, Cserkúti-dombok; Cserkút, DK; Cserkút, Szentmiklós; Hetvehely, Bükkösdi-v.; Mánfa, Nagy-Mély-v.; Pécs, Deindol; Pécs, Mecsekszentkút, erdészház; Pécs, Tettye; Pécs, Tubes.

Ligdia adustata ([Denis \& Schiffermüller], 1775) - Abaliget, Nyáras-v.; Abaliget, üdülők; Bakonya, erdészház; Bakonya, Nagy-Rege; Bakonya, Sás-v.; Bükkösd, Bükkösdi-v.; Bükkösd, Szentdomján; Cserkút, Cserkúti-dombok; Cserkút, DK; Cserkút, Szentmiklós; Hetvehely, Bükkösdi-v.; Kővágószőlős, Kajdács-dülő; Kővágószőlős, Petőc-akna; Mánfa, Nagy-Mély-v.; Orfü, Cigány-h.; Pécs, Árpád-tető; Pécs, Deindol; Pécs, Éger-v.; Pécs, Mecsekszentkút, erdészház; Pécs, Mecsekszentkút, Szunyola; Pécs, Tettye; Pécs, Tubes.

Stegania cararia (Hübner, 1790) (= Lomographa c.) - Bakonya, Nagy-Rege; Kővágószőlős, Petőc-akna; Pécs, Deindol; Pécs, Mecsekszentkút, erdészház.

Stegania dilectaria (Hübner, 1790) (= Lomographa d.) - Cserkút, DK; Cserkút, Szentmiklós.

Heliomata glarearia ([Denis \& Schiffermüller], 1775) (= Semiothisa g.) - Bükkösd, Bükkösdi-v.; Cserkút, DK; Cserkút, Szentmiklós; Hetvehely, Bükkösdi-v.; Kővágószőlős, Kajdács-dülő; Pécs, Deindol; Pécs, Tettye; Pécs, Tubes.

Macaria notata (Linnaeus, 1758) (= Semiothisa n.) - Abaliget, üdülők; Bakonya, erdészház; Cserkút, DK; Pécs, Deindol; Pécs, Mecsekszentkút, erdészház; Mánfa, Nagy-Mély-v.

Macaria alternata ([Denis \& Schiffermüller], 1775) (= Semiothisa a.) - Abaliget, Nyáras-v.; Abaliget, üdülők; Bakonya, erdészház; Bakonya, Nagy-Rege; Bükkösd, Bükkösdi-v.; Cserkút, Cserkúti-dombok; Cserkút, DK; Cserkút, Szentmiklós; Kővágószőlős, Kajdács-dűlő; Kővágószőlős, Petőc-akna; Mánfa, NagyMély-v.; Orfü, Cigány-h.; Pécs, Deindol; Pécs, Mecsekszentkút, erdészház; Pécs, Mecsekszentkút, Szunyola; Pécs, Tettye. 
Macaria liturata (Clerck, 1759) - Abaliget, üdülők; Cserkút, Cserkúti-dombok; Pécs, Deindol; Pécs, Mecsekszentkút, Szunyola.

Macaria brunneata (Thunberg, 1784) (= Itame fulvaria) - Cserkút, Szentmiklós; Mánfa, Nagy-Mély-v.

Chiasmia clathrata (Linnaeus, 1758) (= Semiothisa c.) - Abaliget, Nyáras-v.; Abaliget, üdülők; Bakonya, erdészház; Bakonya, Nagy-Rege; Bakonya, Sás-v.; Bükkösd, Bükkösdi-v.; Cserkút, Cserkúti-dombok; Cserkút, DK; Cserkút, Szentmiklós; Hetvehely, Bükkösdi-v.; Kővágószőlős, Kajdács-dűlő; Kővágószőlős, Petőc-akna; Mánfa, Nagy-Mély-v.; Pécs, Deindol; Pécs, Mecsekszentkút, erdészház; Pécs, Tettye.

Tephrina arenacearia ([Denis \& Schiffermüller], 1775) - Bakonya, Nagy-Rege; Cserkút, DK; Cserkút, Szentmiklós; Pécs, Deindol; Pécs, Mecsekszentkút, Szunyola.

Cepphis advenaria (Hübner, 1790) - Bükkösd, Bükkösdi-v.; Mánfa, Nagy-Mély-v.

Petrophora chlorosata (Scopoli, 1763) (= Lithina ch.) - Bakonya, erdészház; Cserkút, Cserkúti-dombok.

Plagodis pulveraria (Linnaeus, 1758) - Abaliget, Nyáras-v.; Abaliget, üdülők; Bakonya, Nagy-Rege; Bakonya, Sás-v.; Cserkút, Szentmiklós; Kővágószőlős, Petőc-akna; Mánfa, Nagy-Mély-v.; Orfü, Cigány-h.; Pécs, Deindol; Pécs, Éger-v.; Pécs, Mecsekszentkút, erdészház; Pécs, Mecsekszentkút, Szunyola; Pécs, Tettye.

Plagodis dolabraria (Linnaeus, 1767) - Abaliget, Nyáras-v.; Abaliget, üdülők; Bakonya, erdészház; Bakonya, Sás-v.; Cserkút, Cserkúti-dombok; Cserkút, DK; Cserkút, Szentmiklós; Kővágószőlős, Petőc-akna; Mánfa, Nagy-Mély-v.; Orfü, Cigány-h.; Pécs, Deindol; Pécs, Éger-v.; Pécs, Mecsekszentkút, erdészház; Pécs, Mecsekszentkút, Szunyola.

Opisthograptis luteolata (Linnaeus, 1758) - Abaliget, üdülők; Bakonya, erdészház; Bakonya, Nagy-Rege; Cserkút, Cserkúti-dombok; Cserkút, DK; Cserkút, Szentmiklós; Kővágószőlős, Petőc-akna; Mánfa, NagyMély-v.; Orfü, Cigány-h.; Pécs, Deindol; Pécs, Mecsekszentkút, erdészház; Pécs, Mecsekszentkút, Szunyola; Pécs, Tettye.

Epione repandaria (Hufnagel, 1767) - Abaliget, üdülök; Bakonya, erdészház; Hetvehely, Bükkösdi-v.; Mánfa, Nagy-Mély-v.; Pécs, Deindol.

Therapis flavicaria ([Denis \& Schiffermüller], 1775) - Bükkösd, Szentdomján; Cserkút, Cserkúti-dombok; Cserkút, Szentmiklós; Mánfa, Nagy-Mély-v.; Pécs, Deindol.

Pseudopanthera macularia (Linnaeus, 1758) - Bakonya, erdészház; Bakonya, Nagy-Rege; Bükkösd, Bükkösdi-v.; Bükkösd, Szentdomján; Cserkút, Cserkúti-dombok; Cserkút, DK; Cserkút, Szentmiklós; Hetvehely, Bükkösdi-v.; Kővágószőlős, Kajdács-dűlő; Kővágószőlős, Petőc-akna; Pécs, Deindol; Pécs, Éger-v.; Pécs, Remete-rét; Pécs, Tubes.

Eilicrinia cordiaria (Hübner, 1790) - Bükkösd, Bükkösdi-v.; Bükkösd, Szentdomján.

Hypoxystis pluviaria (Fabricius, 1787) - Bükkösd, Bükkösdi-v.; Bükkösd, Szentdomján; Hetvehely, Bükkösdi-v.

Apeira syringaria (Linnaeus, 1758) - Abaliget, üdülők; Bakonya, erdészház; Bükkösd, Bükkösdi-v.; Cserkút, Cserkúti-dombok; Cserkút, Szentmiklós; Mánfa, Nagy-Mély-v.; Pécs, Deindol; Pécs, Mecsekszentkút, Szunyola; Pécs, Tettye; Pécs, Tubes.

Ennomos quercinaria (Hufnagel, 1767) - Cserkút, DK; Cserkút, Szentmiklós; Mánfa, Nagy-Mély-v.; Orfü, Cigány-h.; Pécs, Deindol; Pécs, Mecsekszentkút, Szunyola.

Ennomos fuscantaria (Haworth, 1809) - Abaliget, üdülök; Cserkút, Cserkúti-dombok; Orfü, Cigány-h.; Pécs, Deindol.

Ennomos erosaria ([Denis \& Schiffermüller], 1775) (=E. tiliaria) - Bakonya, erdészház; Bakonya, NagyRege; Bükkösd, Bükkösdi-v.; Cserkút, Cserkúti-dombok; Cserkút, DK; Cserkút, Szentmiklós; Kővágószőlős, Kajdács-dűlő; Kővágószőlős, Petőc-akna; Mánfa, Nagy-Mély-v.; Orfü, Cigány-h.; Pécs, Deindol; Pécs, Mecsekszentkút, Szunyola.

Selenia dentaria (Fabricius, 1775) (= S. bilunaria) - Abaliget, Nyáras-v.; Abaliget, üdülők; Bükkösd, Bükkösdi-v.; Cserkút, Cserkúti-dombok; Cserkút, DK; Kővágószőlős, Petőc-akna; Mánfa, Nagy-Mély-v.; Orfü, Cigány-h.; Pécs, Deindol; Pécs, Mecsekszentkút, Szunyola; Pécs, Mecsekszentkút, erdészház; Pécs, Tettye. 
Selenia lunularia (Hübner, 1788) (= lunaria) - Abaliget, üdülők; Cserkút, Cserkúti-dombok; Cserkút, DK; Cserkút, Szentmiklós; Mánfa, Nagy-Mély-v.; Pécs, Deindol; Pécs, Mecsekszentkút, erdészház; Pécs, Mecsekszentkút, Szunyola; Pécs, Tettye.

Selenia tetralunaria (Hufnagel, 1767) - Abaliget, Nyáras-v.; Abaliget, üdülők; Bakonya, erdészház; Cserkút, Cserkúti-dombok; Cserkút, Szentmiklós; Hetvehely, Bükkösdi-v.; Kővágószőlős, Petőc-akna; Kővágótöttös, Bicsérdi-vízf.; Mánfa, Nagy-Mély-v.; Orfü, Cigány-h.; Pécs, Deindol; Pécs, Éger-v.; Pécs, Mecsekszentkút, erdészház; Pécs, Mecsekszentkút, Szunyola.

Artiora evonymaria ([Denis \& Schiffermüller], 1775) - Bakonya, erdészház; Cserkút, Cserkúti-dombok; Cserkút,

DK; Cserkút, Szentmiklós; Kővágószőlős, Kajdács-dűlő; Mánfa, Nagy-Mély-v.; Pécs, Deindol; Pécs, Éger-v.; Pécs, Mecsekszentkút, Szunyola; Pécs, Tettye.

Crocallis elinguaria (Linnaeus, 1758) - Abaliget, üdülők; Bakonya, Nagy-Rege; Cserkút, Cserkúti-dombok; Cserkút, DK; Cserkút, Szentmiklós; Mánfa, Nagy-Mély-v.; Pécs, Deindol.

Ourapteryx sambucaria (Linnaeus, 1758) - Abaliget, Nyáras-v.; Bakonya, erdészház; Cserkút, DK; Cserkút, Szentmiklós; Mánfa, Nagy-Mély-v.; Orfü, Cigány-h.; Pécs, Deindol; Pécs, Tettye.

Colotois pennaria (Linnaeus, 1761) - Abaliget, üdülők; Bakonya, erdészház; Cserkút, DK; Cserkút, Szentmiklós; Kővágószőlős, Kajdács-dűlő; Kővágószőlős, Petőc-akna; Mánfa, Nagy-Mély-v.; Orfü, Cigány-h.; Pécs, Deindol; Pécs, Éger-v.; Pécs, Tettye.

Angerona prunaria (Linnaeus, 1758) - Abaliget, Nyáras-v.; Abaliget, üdülők; Bakonya, erdészház; Bakonya, Nagy-Rege; Bükkösd, Bükkösdi-v.; Bükkösd, Szentdomján; Cserkút, Cserkúti-dombok; Cserkút, DK; Cserkút, Szentmiklós; Hetvehely, Bükkösdi-v.; Kővágószőlős, Kajdács-dűlő; Kővágószőlős, Petőc-akna; Mánfa, NagyMély-v.; Orfü, Cigány-h.; Pécs, Deindol; Pécs, Mecsekszentkút, Szunyola; Pécs, Tettye; Pécs, Tubes.

Apocheima hispidaria ([Denis \& Schiffermüller], 1775) - Bakonya, erdészház; Bükkösd, Bükkösdi-v.; Bükkösd, Szentdomján; Cserkút, Cserkúti-dombok; Cserkút, DK; Cserkút, vízmü környék; Mánfa, NagyMély-v.; Orfü, Cigány-h.; Pécs, Deindol; Pécs, Tettye.

Apocheima pilosaria ([Denis \& Schiffermüller], 1775) (= Phigalia p.) - Bakonya, erdészház; Bükkösd, Bükkösdi-v.; Cserkút, DK; Orfü, Cigány-h.; Pécs, Árpád-tető; Pécs, Deindol; Pécs, Éger-v.; Pécs, Tettye.

Lycia hirtaria (Clerck, 1759) - Abaliget, Nyáras-v.; Abaliget, üdülők; Bükkösd, Bükkösdi-v.; Cserkút, DK; Hetvehely, Bükkösdi-v.; Kővágószőlős, Kajdács-dűlő; Kővágótöttös, Bicsérdi-vízf.; Pécs, Deindol; Pécs, Mecsekszentkút, Szunyola.

Lycia pomonaria (Hübner, 1790) (= Poecilopsis p.) - Bakonya, erdészház; Pécs, Deindol.

Biston strataria (Hufnagel, 1767) - Bakonya, erdészház; Bükkösd, Bükkösdi-v.; Bükkösd, Szentdomján; Cserkút, Cserkúti-dombok; Cserkút, DK; Cserkút, vízmü környék; Mánfa, Nagy-Mély-v.; Orfü, Cigány-h.; Pécs, Árpád-tető; Pécs, Deindol; Pécs, Mecsekszentkút, Szunyola; Pécs, Tettye.

Biston betularia (Linnaeus, 1758) - Abaliget, üdülők; Bakonya, erdészház; Bakonya, Nagy-Rege; Bakonya, Sás-v.; Cserkút, Cserkúti-dombok; Cserkút, DK; Cserkút, Szentmiklós; Mánfa, Nagy-Mély-v.; Pécs, Deindol; Pécs, Tettye.

Agriopis leucophaearia ([Denis \& Schiffermüller], 1775) (= Erannis l.) - Abaliget, üdülők; Bakonya, erdészház; Bükkösd, Bükkösdi-v.; Cserkút, Cserkúti-dombok; Cserkút, DK; Cserkút, vízmű környék; Orfü, Cigány-h.; Orfü, Vörös-h.; Pécs, Árpád-tető; Pécs, Deindol; Pécs, Éger-v.; Pécs, Mecsekszentkút, erdészház; Pécs, Tettye.

Agriopis bajaria ([Denis \& Schiffermüller], 1775) (= Erannis b.) - Abaliget, üdülök; Bakonya, erdészház; Cserkút, DK; Cserkút, vízmű környék; Kővágószőlős, Kajdács-dűlő; Mánfa, Nagy-Mély-v.; Orfü, Cigány-h.; Pécs, Deindol; Pécs, Éger-v.; Pécs, Tettye.

Agriopis aurantiaria (Hübner, 1799) (= Erannis a.) - Abaliget, üdülők; Bakonya, erdészház; Cserkút, DK; Mánfa, Nagy-Mély-v.; Pécs, Deindol; Pécs, Éger-v.; Pécs, Mecsekszentkút, Szunyola; Pécs, Tettye.

Agriopis marginaria (Fabricius, 1776) (= Erannis m.) - Bakonya, erdészház; Bükkösd, Bükkösdi-v.; Bükkösd, Szentdomján; Cserkút, Cserkúti-dombok; Cserkút, DK; Cserkút, vízmü környék; Mánfa, NagyMély-v.; Orfü, Cigány-h.; Orfü, Vörös-h.; Pécs, Árpád-tető; Pécs, Deindol; Pécs, Éger-v.; Pécs, Mecsekszentkút, Szunyola; Pécs, Tettye. 
Erannis defoliaria (Clerck, 1759) - Abaliget, üdülők; Bakonya, erdészház; Cserkút, DK; Cserkút, Szentmiklós; Mánfa, Nagy-Mély-v.; Pécs, Deindol; Pécs, Éger-v.; Pécs, Remete-rét; Pécs, Tettye.

Synopsia sociaria (Hübner, 1799) - Bakonya, Nagy-Rege; Cserkút, Cserkúti-dombok; Cserkút, DK; Cserkút, Szentmiklós; Kővágószőlős, Kajdács-dűlő; Pécs, Deindol.

Peribatodes rhomboidaria ([Denis \& Schiffermüller], 1775) - Abaliget, Nyáras-v.; Abaliget, üdülök; Bakonya, erdészház; Bakonya, Nagy-Rege; Bükkösd, Bükkösdi-v.; Bükkösd, Szentdomján; Cserkút, Cserkútidombok; Cserkút, DK; Cserkút, Szentmiklós; Hetvehely, Bükkösdi-v.; Kővágószőlős, Kajdács-dülő; Kővágótöttös, Cserma-h.; Mánfa, Nagy-Mély-v.; Orfü, Cigány-h.; Pécs, Deindol; Pécs, Mecsekszentkút, erdészház; Pécs, Mecsekszentkút, Szunyola; Pécs, Tettye; Pécs, Tubes.

Selidosema brunnearia (Villers, 1789) (= S. plumaria)- Cserkút, Cserkúti-dombok; Cserkút, DK; Kővágószőlős, Kajdács-dülő.

Cleora cinctaria ([Denis \& Schiffermüller], 1775) - Cserkút, Cserkúti-dombok; Cserkút, DK; Cserkút, Szentmiklós; Hetvehely, Bükkösdi-v.; Kővágószőlős, Kajdács-dűlő; Pécs, Deindol; Pécs, Tettye.

Alcis repandata (Linnaeus, 1758) - Abaliget, Nyáras-v.; Abaliget, üdülők; Bakonya, erdészház; Cserkút, Cserkúti-dombok; Mánfa, Nagy-Mély-v.; Orfü, Cigány-h.; Pécs, Deindol; Pécs, Mecsekszentkút, Szunyola.

Hypomecis roboraria ([Denis \& Schiffermüller], 1775) - Abaliget, Nyáras-v.; Bakonya, Nagy-Rege; Cserkút, Cserkúti-dombok; Mánfa, Nagy-Mély-v.; Orfü, Cigány-h.; Pécs, Deindol; Pécs, Mecsekszentkút, erdészház.

Hypomecis danieli (Wehrli, 1932) (= Boarmia d.) - Abaliget, üdülők; Bakonya, erdészház; Bükkösd, Bükkösdi-v.; Cserkút, Cserkúti-dombok; Cserkút, DK; Cserkút, Szentmiklós; Hetvehely, Bükkösdi-v.; Kővágószőlős, Kajdács-dülő; Kővágószőlős, Petőc-akna; Mánfa, Nagy-Mély-v.; Pécs, Deindol; Pécs, Mecsekszentkút, Szunyola.

Hypomecis punctinalis (Scopoli, 1763) (= Boarmia p.) - Abaliget, Nyáras-v.; Abaliget, üdülők; Bakonya, erdészház; Bakonya, Nagy-Rege; Bakonya, Sás-v.; Bükkösd, Bükkösdi-v.; Bükkösd, Szentdomján; Cserkút, Cserkúti-dombok; Cserkút, DK; Cserkút, Szentmiklós; Hetvehely, Bükkösdi-v.; Kővágószőlős, Kajdács-dűlő; Kővágószőlős, Petőc-akna; Mánfa, Nagy-Mély-v.; Orfü, Cigány-h.; Pécs, Deindol; Pécs, Mecsekszentkút, erdészház; Pécs, Mecsekszentkút, Szunyola; Pécs, Tettye; Pécs, Tubes.

Fagivorina arenaria (Hufnagel, 1767) - Kővágószőlős, Petőc-akna; Mánfa, Nagy-Mély-v.; Orfü, Cigány-h.; Pécs, Deindol; Pécs, Éger-v.; Pécs, Mecsekszentkút, erdészház.

Ascotis selenaria ([Denis \& Schiffermüller], 1775) - Abaliget, Nyáras-v.; Abaliget, üdülők; Bakonya, erdészház; Bakonya, Nagy-Rege; Bakonya, Sás-v.; Bükkösd, Bükkösdi-v.; Bükkösd, Szentdomján; Cserkút, Cserkúti-dombok; Cserkút, DK; Cserkút, Szentmiklós; Hetvehely, Bükkösdi-v.; Kővágószőlős, Kajdács-dűlő; Kővágószőlős, Petőc-akna; Mánfa, Nagy-Mély-v.; Orfü, Cigány-h.; Pécs, Deindol; Pécs, Mecsekszentkút, erdészház; Pécs, Mecsekszentkút, Szunyola; Pécs, Tettye; Pécs, Tubes.

Ectropis crepuscularia ([Denis \& Schiffermüller], 1775) (=E. bistortata) - Abaliget, Nyáras-v.; Abaliget, üdülök; Bakonya, erdészház; Bükkösd, Bükkösdi-v.; Cserkút, Cserkúti-dombok; Cserkút, Szentmiklós; Hetvehely, Bükkösdi-v.; Kővágószőlős, Kajdács-dűlő; Kővágószőlős, Petőc-akna; Mánfa, Nagy-Mély-v.; Orfü, Cigány-h.; Pécs, Árpád-tető; Pécs, Deindol; Pécs, Éger-v.; Pécs, Mecsekszentkút, erdészház; Pécs, Mecsekszentkút, Szunyola; Pécs, Tettye.

Parectropis similaria (Hufnagel, 1767) (= Ectropis extersaria) - Cserkút, Szentmiklós; Mánfa, NagyMély-v.

Aethalura punctulata ([Denis \& Schiffermüller], 1775) - Hetvehely, Bükkösdi-v.

Ematurga atomaria (Linnaeus, 1758) - Abaliget, Nyáras-v.; Abaliget, üdülők; Bakonya, erdészház; Bakonya, Nagy-Rege; Bakonya, Sás-v.; Bükkösd, Bükkösdi-v.; Bükkösd, Szentdomján; Cserkút, Cserkútidombok; Cserkút, DK; Cserkút, Szentmiklós; Hetvehely, Bükkösdi-v.; Kővágószőlős, Kajdács-dülő; Kővágószőlős, Petőc-akna; Mánfa, Nagy-Mély-v.; Pécs, Árpád-tető; Pécs, Deindol; Pécs, Éger-v.; Pécs, Mecsekszentkút, Szunyola; Pécs, Tettye.

Bupalus piniarius (Linnaeus, 1758) - Abaliget, üdülők; Cserkút, Cserkúti-dombok; Cserkút, Szentmiklós; Pécs, Tettye. 
Cabera pusaria (Linnaeus, 1758) - Abaliget, Nyáras-v.; Abaliget, üdülők; Bükkösd, Bükkösdi-v.; Bükkösd, Szentdomján; Cserkút, DK; Cserkút, Szentmiklós; Mánfa, Nagy-Mély-v.; Pécs, Mecsekszentkút, Szunyola; Pécs, Tettye.

Cabera exanthemata (Scopoli, 1763) - Abaliget, Nyáras-v.; Abaliget, üdülők; Bakonya, erdészház; Bükkösd, Bükkösdi-v.; Bükkösd, Szentdomján; Cserkút, DK; Cserkút, Szentmiklós; Hetvehely, Bükkösdi-v.; Mánfa, Nagy-Mély-v.; Pécs, Deindol; Pécs, Tubes.

Lomographa bimaculata (Fabricius, 1775) (=Bapta b.) - Abaliget, Nyáras-v.; Abaliget, üdülök; Bakonya, erdészház; Bakonya, Sás-v.; Cserkút, Cserkúti-dombok; Cserkút, DK; Cserkút, Szentmiklós; Kővágószőlős, Petőc-akna; Mánfa, Nagy-Mély-v.; Orfü, Cigány-h.; Pécs, Deindol; Pécs, Éger-v.; Pécs, Mecsekszentkút, erdészház; Pécs, Mecsekszentkút, Szunyola.

Lomographa temerata ([Denis \& Schiffermüller], 1775) (= Bapta t.) - Abaliget, Nyáras-v.; Abaliget, üdülők; Bakonya, erdészház; Bakonya, Nagy-Rege; Bakonya, Sás-v.; Bükkösd, Bükkösdi-v.; Bükkösd, Szentdomján; Cserkút, Cserkúti-dombok; Cserkút, DK; Cserkút, Szentmiklós; Kővágószőlős, Petőc-akna; Mánfa, Nagy-Mély-v.; Orfü, Cigány-h.; Pécs, Deindol; Pécs, Mecsekszentkút, erdészház; Pécs, Mecsekszentkút, Szunyola; Pécs, Tettye.

Theria rupicapraria ([Denis \& Schiffermüller], 1775) - Bükkösd, Bükkösdi-v.; Cserkút, DK; Cserkút, vízmű környék; Pécs, Deindol; Pécs, Tettye.

Campaea margaritata (Linnaeus, 1767) - Abaliget, Nyáras-v.; Abaliget, üdülök; Bakonya, erdészház; Bakonya, Nagy-Rege; Bükkösd, Bükkösdi-v.; Cserkút, Cserkúti-dombok; Cserkút, DK; Cserkút, Szentmiklós; Hetvehely, Bükkösdi-v.; Kővágószőlős, Kajdács-dűlő; Kővágótöttös, Cserma-h.; Mánfa, Nagy-Mély-v.; Orfü, Cigány-h.; Pécs, Deindol; Pécs, Mecsekszentkút, Szunyola; Pécs, Tettye; Pécs, Tubes.

Hylaea fasciaria (Linnaeus, 1758) (= prosapiaria) - Abaliget, üdülök; Pécs, Mecsekszentkút, Szunyola.

Gnophos furvata ([Denis \& Schiffermüller], 1775) - Pécs, Deindol; Pécs, Tettye.

Charissa obscurata ([Denis \& Schiffermüller], 1775) (= Gnophos o.) - Bakonya, erdészház; Cserkút, DK; Cserkút, Szentmiklós; Kővágótöttös, Cserma-h.; Pécs, Mecsekszentkút, Szunyola; Pécs, Deindol; Pécs, Tettye.

Siona lineata (Scopoli, 1763) - Abaliget, Nyáras-v.; Bakonya, erdészház; Bakonya, Nagy-Rege; Bakonya, Sás-v.; Bükkösd, Bükkösdi-v.; Cserkút, Cserkúti-dombok; Cserkút, DK; Cserkút, Szentmiklós; Hetvehely, Bükkösdi-v.; Kővágószőlős, Kajdács-dűlő; Kővágótöttös, Cserma-h.; Mánfa, Nagy-Mély-v.; Pécs, Deindol; Pécs, Mecsekszentkút, Szunyola.

Dyscia conspersaria ([Denis \& Schiffermüller], 1775) - Pécs, Tettye.

Perconia strigillaria (Hübner, 1787) - Bakonya, erdészház; Bakonya, Nagy-Rege; Cserkút, Cserkútidombok; Cserkút, DK; Cserkút, Szentmiklós; Hetvehely, Bükkösdi-v.; Kővágószőlős, Kajdács-dűlő; Mánfa, Nagy-Mély-v.; Pécs, Deindol; Pécs, Mecsekszentkút, Szunyola.

\section{Notodontidae}

Cerura erminea (Esper, 1783) (= Dicranura e.) - Bakonya, Nagy-Rege; Cserkút, Cserkúti-dombok; Hetvehely, Bükkösdi-v.

Furcula bifida (Brahm, 1787) (= Harpyia b.) - Bükkösd, Bükkösdi-v.; Cserkút, Szentmiklós.

Furcula furcula (Clerck, 1759) (= Harpyia f.) - Abaliget, üdülők; Cserkút, DK; Hetvehely, Bükkösdi-v.

Harpyia milhauseri (Fabricius, 1775) (=Hoplitis m., Hybocampa m.) - Cserkút, Cserkúti-dombok; Cserkút, DK; Cserkút, Szentmiklós; Pécs, Deindol; Pécs, Mecsekszentkút, Szunyola; Pécs, Tettye.

Stauropus fagi (Linnaeus, 1758) - Abaliget, Nyáras-v.; Abaliget, üdülők; Bakonya, Nagy-Rege; Cserkút, Cserkúti-dombok; Cserkút, DK; Cserkút, Szentmiklós; Hetvehely, Bükkösdi-v.; Mánfa, Nagy-Mély-v.; Pécs, Deindol; Pécs, Mecsekszentkút, erdészház; Pécs, Mecsekszentkút, Szunyola; Pécs, Tubes.

Dicranura ulmi ([Denis \& Schiffermüller], 1775) (= Exaereta u.) - Cserkút, DK; Kővágószőlős, Kajdácsdülö.

Drymonia velitaris (Hufnagel, 1766) (= Ochrostigma v.) - Abaliget, Nyáras-v.; Abaliget, üdülők; Bakonya, erdészház; Bakonya, Nagy-Rege; Cserkút, Szentmiklós. 
Drymonia obliterata (Esper, 1785) (= Ochrostigma melagona) - Abaliget, Nyáras-v.; Abaliget, üdülők; Bakonya, Nagy-Rege; Bakonya, Sás-v.; Cserkút, Cserkúti-dombok; Cserkút, Szentmiklós; Kővágószőlős, Petőc-akna; Kővágótöttös, Cserma-h.; Mánfa, Nagy-Mély-v.; Pécs, Deindol; Pécs, Mecsekszentkút, Szunyola; Pécs, Tettye.

Drymonia dodonaea ([Denis \& Schiffermüller], 1775) (= D. trimacula) - Abaliget, Nyáras-v.; Bakonya, erdészház; Cserkút, Cserkúti-dombok; Cserkút, DK; Cserkút, Szentmiklós; Hetvehely, Bükkösdi-v.; Mánfa, Nagy-Mély-v.; Orfü, Cigány-h.; Pécs, Deindol; Pécs, Mecsekszentkút, erdészház; Pécs, Tettye; Pécs, Tubes.

Drymonia ruficornis (Hufnagel, 1766) - Abaliget, Nyáras-v.; Bakonya, erdészház; Bükkösd, Bükkösdi-v.; Cserkút, Cserkúti-dombok; Cserkút, DK; Cserkút, Szentmiklós; Hetvehely, Bükkösdi-v.; Kővágószőlős, Kajdács-dűlő; Kővágószőlős, Petőc-akna; Mánfa, Nagy-Mély-v.; Orfü, Cigány-h.; Pécs, Árpád-tető; Pécs, Deindol; Pécs, Mecsekszentkút, erdészház; Pécs, Mecsekszentkút, Szunyola; Pécs, Tettye.

Drymonia querna ([Denis \& Schiffermüller], 1775) - Abaliget, üdülök; Bakonya, Nagy-Rege; Bükkösd, Bükkösdi-v.; Cserkút, Cserkúti-dombok; Cserkút, DK; Cserkút, Szentmiklós; Kővágószőlős, Petőc-akna; Mánfa, Nagy-Mély-v.; Pécs, Deindol; Pécs, Mecsekszentkút, Szunyola; Pécs, Tettye.

Gluphisia crenata (Esper, 1785) - Cserkút, DK.

Notodonta tritophus ([Denis \& Schiffermüller], 1775) (= phoebe (Siebert, 1790)) - Abaliget, üdülők.

Notodonta dromedarius (Linnaeus, 1758) - Abaliget, Nyáras-v.; Abaliget, üdülők; Bükkösd, Szentdomján; Cserkút, Szentmiklós; Hetvehely, Bükkösdi-v.; Pécs, Deindol.

Notodonta ziczac (Linnaeus, 1758) - Bükkösd, Bükkösdi-v.; Cserkút, Cserkúti-dombok; Cserkút, Szentmiklós; Kővágószőlős, Petőc-akna; Pécs, Deindol; Pécs, Mecsekszentkút, Szunyola.

Peridea anceps (Goeze, 1781) - Abaliget, Nyáras-v.; Bakonya, erdészház; Cserkút, DK; Cserkút, Szentmiklós; Mánfa, Nagy-Mély-v.; Orfü, Cigány-h.; Pécs, Mecsekszentkút, erdészház.

Pheosia tremula (Clerck, 1759) - Cserkút, Cserkúti-dombok; Hetvehely, Bükkösdi-v.; Pécs, Mecsekszentkút, Szunyola.

Pterostoma palpina (Clerck, 1759) - Abaliget, üdülők; Bükkösd, Bükkösdi-v.; Cserkút, Cserkúti-dombok; Cserkút, DK; Cserkút, Szentmiklós; Hetvehely, Bükkösdi-v.; Kővágószőlős, Kajdács-dűlő; Pécs, Deindol; Pécs, Mecsekszentkút, Szunyola.

Spatalia argentina ([Denis \& Schiffermüller], 1775) - Abaliget, Nyáras-v.; Abaliget, üdülők; Bakonya, erdészház; Bakonya, Nagy-Rege; Bükkösd, Szentdomján; Cserkút, Cserkúti-dombok; Hetvehely, Bükkösdi-v.; Kővágószőlős, Kajdács-dűlő; Kővágószőlős, Petőc-akna; Kővágótöttös, Cserma-h.; Mánfa, Nagy-Mély-v.; Orfü, Cigány-h.; Pécs, Deindol; Pécs, Mecsekszentkút, Szunyola; Pécs, Tettye; Pécs, Tubes.

Ptilodon capucina (Linnaeus, 1758) (= Lophopteryx camelina) - Abaliget, Nyáras-v.; Bükkösd, Szentdomján; Mánfa, Nagy-Mély-v.; Orfü, Cigány-h.

Ptilodon cucullina ([Denis \& Schiffermüller], 1775) (= Lophopteryx cuculla) - Abaliget, Nyáras-v.; Abaliget, üdülök; Bakonya, Nagy-Rege; Bükkösd, Szentdomján; Cserkút, Cserkúti-dombok; Cserkút, DK; Hetvehely, Bükkösdi-v.; Kővágószőlős, Kajdács-dülő; Kővágószőlős, Petőc-akna; Mánfa, Nagy-Mély-v.; Pécs, Deindol; Pécs, Mecsekszentkút, erdészház; Pécs, Mecsekszentkút, Szunyola; Pécs, Tubes.

Ptilophora plumigera ([Denis \& Schiffermüller], 1775) - Abaliget, üdülők; Bakonya, erdészház; Cserkút, DK; Mánfa, Nagy-Mély-v.; Orfü, Cigány-h.; Pécs, Deindol; Pécs, Éger-v.; Pécs, Mecsekszentkút, Szunyola; Pécs, Tettye.

Phalera bucephala (Linnaeus, 1758) - Cserkút, Cserkúti-dombok; Cserkút, DK; Kővágószőlős, Kajdácsdülö.

Phalera bucephaloides (Ochsenheimer, 1810) - Cserkút, Cserkúti-dombok; Cserkút, DK; Cserkút, Szentmiklós; Pécs, Deindol; Pécs, Mecsekszentkút, Szunyola.

Clostera anastomosis (Linnaeus, 1758) - Bükkösd, Bükkösdi-v.; Cserkút, Cserkúti-dombok; Mánfa, NagyMély-v.

Clostera curtula (Linnaeus, 1758) - Abaliget, Nyáras-v.; Abaliget, üdülök; Bükkösd, Bükkösdi-v.; Cserkút, Cserkúti-dombok; Cserkút, Szentmiklós; Kővágószőlős, Kajdács-dűlő; Mánfa, Nagy-Mély-v.

Clostera pigra (Hufnagel, 1766) - Bakonya, erdészház; Bakonya, Sás-v.; Cserkút, Szentmiklós; Hetvehely, Bükkösdi-v.; Kővágószőlős, Kajdács-dülő; Kővágószőlős, Petőc-akna; Mánfa, Nagy-Mély-v.; Pécs, Deindol. 
Thaumetopoea processionea (Linnaeus, 1758) - Cserkút, DK; Cserkút, Szentmiklós; Mánfa, NagyMély-v.

\section{Erebidae (Noctuidae s.1.) \\ Rivulinae}

Rivula sericealis (Scopoli, 1763) - Abaliget, Nyáras-v.; Abaliget, üdülők; Bakonya, erdészház; Bakonya, Nagy-Rege; Bükkösd, Bükkösdi-v.; Cserkút, Cserkúti-dombok; Cserkút, DK; Cserkút, Szentmiklós; Hetvehely, Bükkösdi-v.; Kővágószőlős, Kajdács-dülő; Kővágótöttös, Cserma-h.; Mánfa, Nagy-Mély-v.; Orfü, Cigány-h.; Pécs, Deindol; Pécs, Mecsekszentkút, Szunyola; Pécs, Tettye; Pécs, Tubes.

\section{Boletobiinae}

Parascotia fuliginaria (Linnaeus, 1761) - Abaliget, üdülök; Bakonya, Nagy-Rege; Orfü, Cigány-h.; Pécs, Deindol.

\section{Hypenodinae}

Schrankia taenialis (Hübner, 1809) - Cserkút, DK; Mánfa, Nagy-Mély-v.

\section{Aventiinae}

Laspeyria flexula ([Denis \& Schiffermüller], 1775) - Abaliget, Nyáras-v.; Abaliget, üdülők; Bakonya, Nagy-Rege; Bükkösd, Szentdomján; Cserkút, Cserkúti-dombok; Hetvehely, Bükkösdi-v.; Kővágószőlős, Kajdács-dülö; Kövágótöttös, Cserma-h.; Orfü, Cigány-h.; Pécs, Deindol.

Trisateles emortualis ([Denis \& Schiffermüller], 1775) - Abaliget, Nyáras-v.; Abaliget, üdülők; Bakonya, Nagy-Rege; Bakonya, Sás-v.; Bükkösd, Szentdomján; Cserkút, Cserkúti-dombok; Cserkút, DK; Kővágószőlős, Petőc-akna; Kővágótöttös, Cserma-h.; Mánfa, Nagy-Mély-v.; Orfü, Cigány-h.; Pécs, Deindol; Pécs, Mecsekszentkút, erdészház; Pécs, Mecsekszentkút, Szunyola; Pécs, Tubes.

\section{Herminiinae}

Simplicia rectalis (Eversmann, 1842) - Cserkút, DK.

Paracolax tristalis (Fabricius, 1794) (= glaucinalis, derivalis) - Abaliget, Nyáras-v.; Abaliget, üdülök; Bakonya, erdészház; Bakonya, Nagy-Rege; Bakonya, Sás-v.; Bükkösd, Bükkösdi-v.; Bükkösd, Szentdomján; Cserkút, DK; Cserkút, Szentmiklós; Kővágószőlős, Petőc-akna; Kővágótöttös, Cserma-h.; Mánfa, NagyMély-v.; Orfü, Cigány-h.; Pécs, Deindol; Pécs, Mecsekszentkút, Szunyola; Pécs, Tettye.

Macrochilo cribrumalis (Hübner, 1793) (= Chytolitha c.) - Mánfa, Nagy-Mély-v.

Herminia tarsipennalis Treitschke, 1835 (=Zanclognatha t.) - Abaliget, Nyáras-v.; Bakonya, erdészház; Bakonya, Nagy-Rege; Bükkösd, Bükkösdi-v.; Cserkút, Cserkúti-dombok; Cserkút, DK; Cserkút, Szentmiklós; Mánfa, Nagy-Mély-v.; Orfü, Cigány-h.; Pécs, Deindol; Pécs, Éger-v.; Pécs, Tettye; Pécs, Tubes.

Herminia tarsicrinalis (Knoch, 1782) (=Zanclognatha t.) - Abaliget, Nyáras-v.; Abaliget, üdülők; Bakonya, erdészház; Bakonya, Nagy-Rege; Bakonya, Sás-v.; Bükkösd, Bükkösdi-v.; Bükkösd, Szentdomján; Cserkút, Cserkúti-dombok; Cserkút, DK; Cserkút, Szentmiklós; Hetvehely, Bükkösdi-v.; Kővágószőlős, Kajdács-dülő; Kővágószőlős, Petőc-akna; Kővágótöttös, Cserma-h.; Mánfa, Nagy-Mély-v.; Orfü, Cigány-h.; Pécs, Deindol; Pécs, Éger-v.; Pécs, Mecsekszentkút, erdészház; Pécs, Mecsekszentkút, Szunyola; Pécs, Tettye; Pécs, Tubes.

Herminia grisealis ([Denis \& Schiffermüller], 1775) (=Zanclognatha g., Z. nemoralis) - Abaliget, Nyáras-v.; Abaliget, üdülők; Bakonya, erdészház; Bakonya, Nagy-Rege; Bakonya, Sás-v.; Cserkút, Cserkútidombok; Cserkút, DK; Cserkút, Szentmiklós; Kővágószőlős, Petőc-akna; Mánfa, Nagy-Mély-v.; Orfü, Cigány-h.; Pécs, Deindol; Pécs, Éger-v.; Pécs, Mecsekszentkút, erdészház; Pécs, Mecsekszentkút, Szunyola; Pécs, Tettye; Pécs, Tubes.

Polypogon tentacularia (Linnaeus, 1758) (= Macrochilo t.) - Abaliget, Nyáras-v.; Abaliget, üdülők; Bakonya, erdészház; Bakonya, Nagy-Rege; Bükkösd, Bükkösdi-v.; Bükkösd, Szentdomján; Cserkút, Cserkútidombok; Cserkút, DK; Cserkút, Szentmiklós; Hetvehely, Bükkösdi-v.; Kővágószőlős, Kajdács-dülő; Kővágótöttös, Cserma-h.; Mánfa, Nagy-Mély-v.; Pécs, Deindol. 


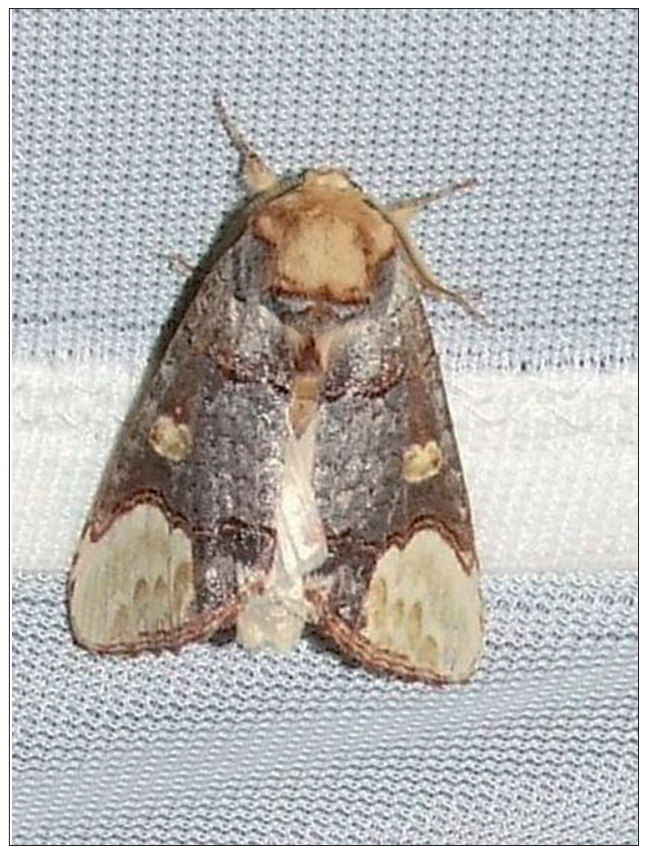

12. ábra: Phalera bucephaloides (Ochsenheimer, 1810) (fotó: Uherkovich Ákos)

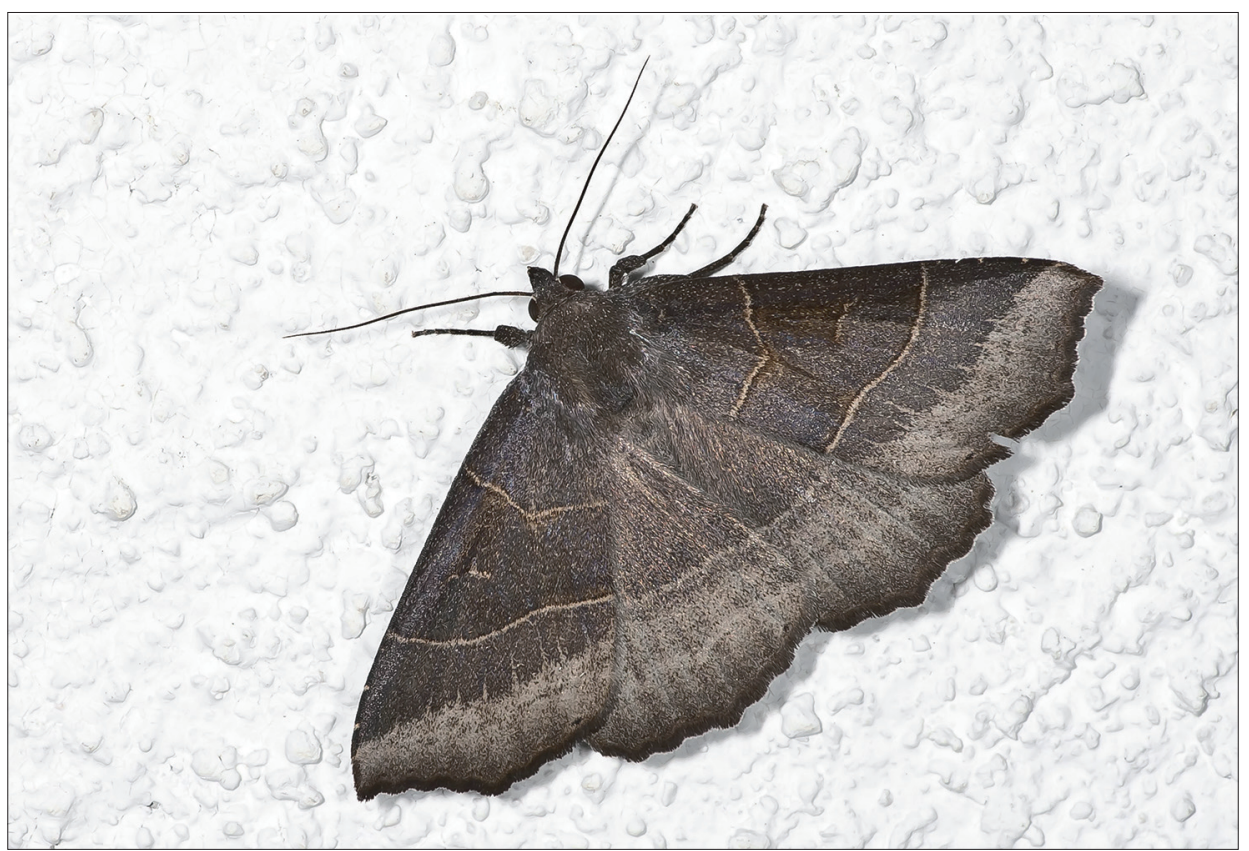

13. ábra: Arytrura musculus (Ménétriés, 1859)

(fotó: Ötvös Károly) 


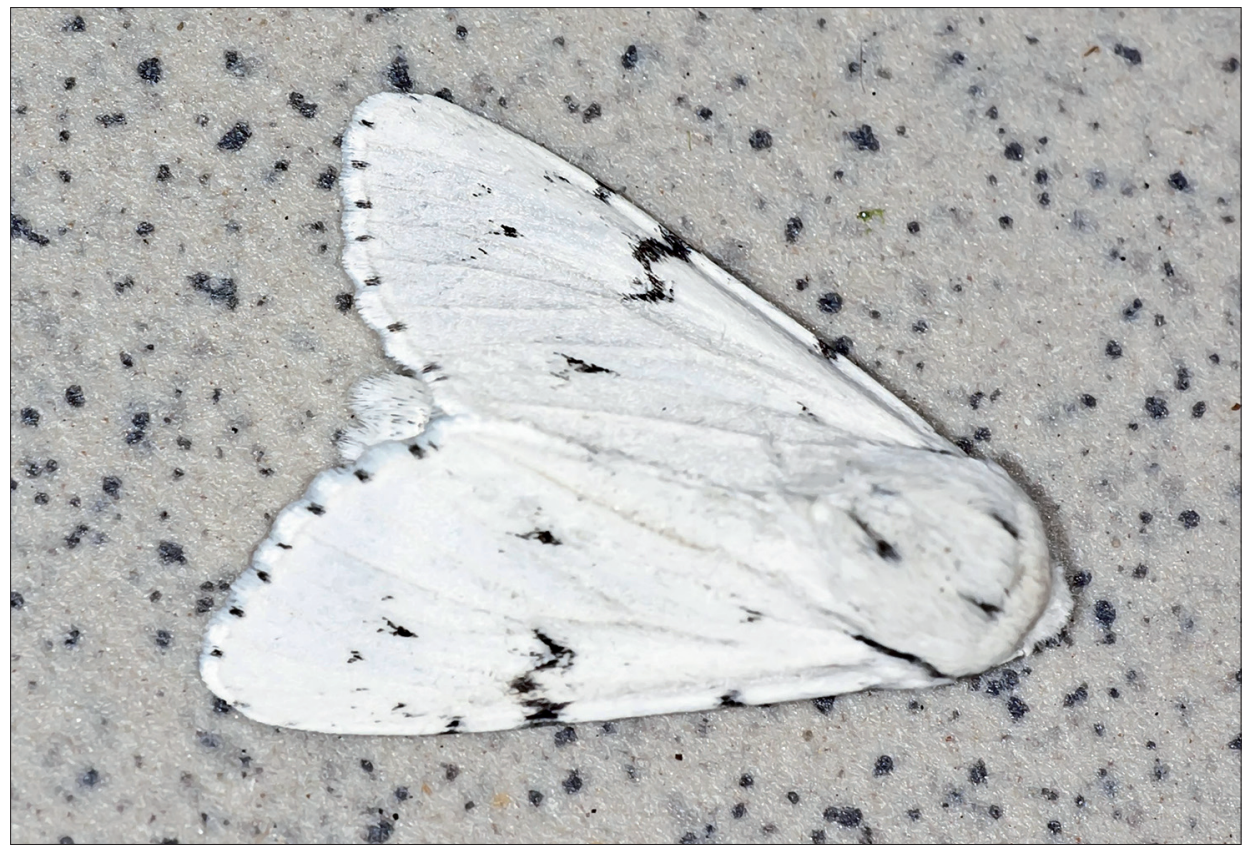

14. ábra: Acronicta leporina (Linnaeus, 1758)

(fotó: Ötvös Károly)

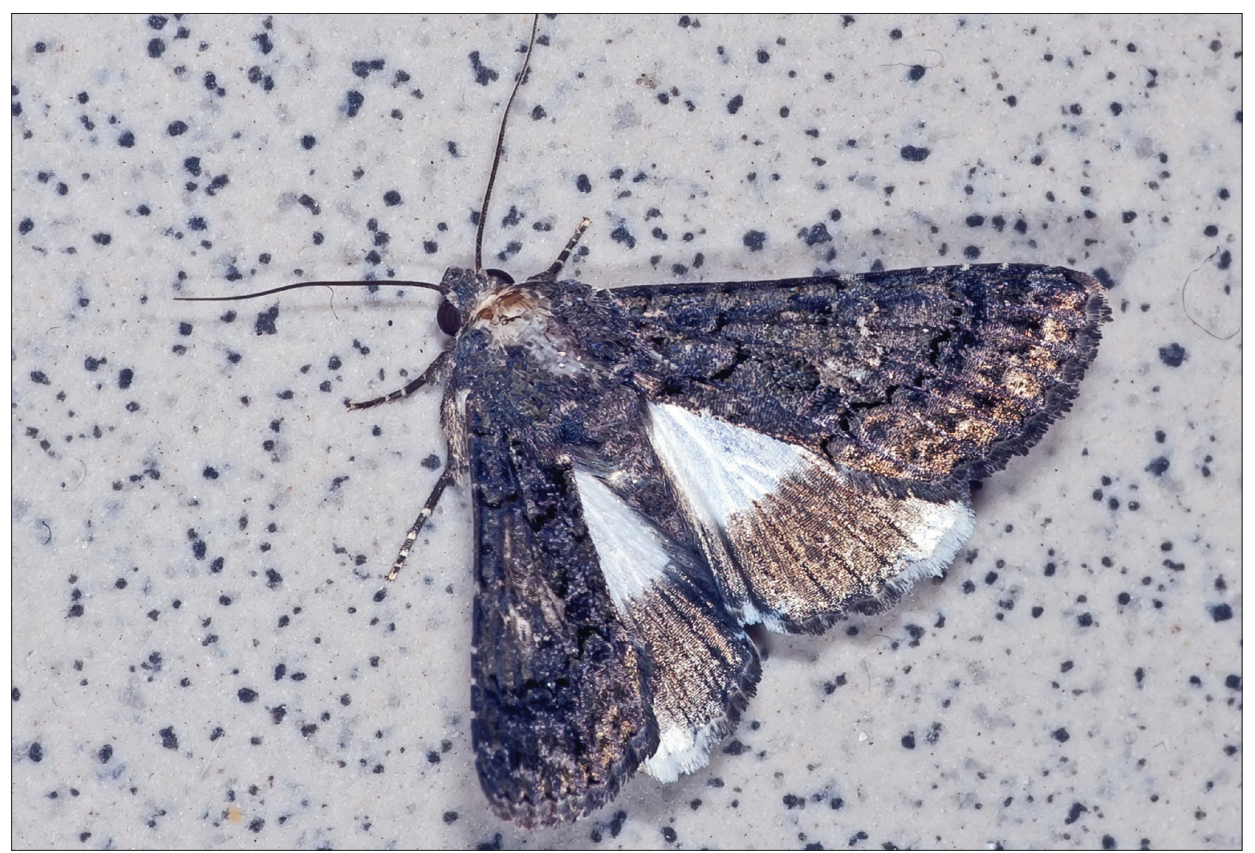

15. ábra: Aedia leucomelas (Linnaeus, 1758)

(fotó: Ötvös Károly) 
Polypogon gryphalis (Herrich-Schäffer, 1851) (= Pechipogo g.) - Bakonya, Nagy-Rege; Bakonya, Sás-v.

Pechipogo strigilata (Linnaeus, 1758) (= Herminia barbaralis) - Abaliget, Nyáras-v.; Bakonya, erdészház; Hetvehely, Bükkösdi-v.; Mánfa, Nagy-Mély-v.; Pécs, Deindol; Pécs, Tettye.

Zanclognatha lunalis (Scopoli, 1763) - Abaliget, üdülök; Bakonya, Nagy-Rege; Bakonya, Sás-v.; Bükkösd, Szentdomján; Cserkút, Cserkúti-dombok; Cserkút, DK; Cserkút, Szentmiklós; Mánfa, Nagy-Mély-v.; Orfü, Cigány-h.; Pécs, Deindol; Pécs, Mecsekszentkút, Szunyola; Pécs, Tettye.

\section{Hypeninae}

Hypena proboscidalis (Linnaeus, 1758) - Abaliget, Nyáras-v.; Abaliget, üdülők; Bakonya, erdészház; Bakonya, Nagy-Rege; Bakonya, Sás-v.; Bükkösd, Bükkösdi-v.; Bükkösd, Szentdomján; Cserkút, Cserkútidombok; Cserkút, DK; Cserkút, Szentmiklós; Kővágótöttös, Cserma-h.; Mánfa, Nagy-Mély-v.; Orfü, Cigány-h.; Pécs, Deindol; Pécs, Mecsekszentkút, erdészház; Pécs, Mecsekszentkút, Szunyola; Pécs, Tettye; Pécs, Tubes.

Hypena rostralis (Linnaeus, 1758) - Abaliget, Nyáras-v.; Abaliget, üdülők; Bakonya, erdészház; Bükkösd, Szentdomján; Cserkút, Cserkúti-dombok; Cserkút, DK; Kővágószőlős, Kajdács-dűlő; Kővágószőlős, Petőcakna; Kővágótöttös, Bicsérdi-vízf.; Mánfa, Nagy-Mély-v.; Orfü, Cigány-h.; Pécs, Deindol; Pécs, Éger-v.; Pécs, Mecsekszentkút, Szunyola; Pécs, Tettye.

\section{Eublemminae}

Calymma communimacula ([Denis \& Schiffermüller], 1775) - Cserkút, Cserkúti-dombok; Cserkút, DK; Pécs, Deindol.

Eublemma parva (Hübner, 1808) (= Porphyrinia p.) - Pécs, Deindol.

Eublemma purpurina ([Denis \& Schiffermüller], 1775) (= Porphyrinia p.) - Cserkút, DK; Cserkút, Szentmiklós; Pécs, Deindol; Pécs, Mecsekszentkút, Szunyola.

\section{Phytometrinae}

Phytometra viridaria (Clerck, 1759) (= Prothymia v.) - Cserkút, DK; Pécs, Deindol.

Colobochyla salicalis ([Denis \& Schiffermüller], 1775) - Abaliget, Nyáras-v.; Bükkösd, Bükkösdi-v.; Cserkút, Cserkúti-dombok; Orfü, Cigány-h.

\section{Calpinae}

Scoliopteryx libatrix (Linnaeus, 1758) - Abaliget, üdülök; Bükkösd, Bükkösdi-v.; Cserkút, Cserkútidombok; Cserkút, DK; Kővágószőlős, Kajdács-dủlő; Mánfa, Nagy-Mély-v.

\section{Lymantriinae}

Lymantria dispar (Linnaeus, 1758) - Abaliget, üdülők; Bükkösd, Szentdomján; Cserkút, Cserkúti-dombok; Cserkút, DK; Cserkút, Szentmiklós; Hetvehely, Bükkösdi-v.; Kővágószőlős, Kajdács-dűlő; Kővágószőlős, Petőc-akna; Mánfa, Nagy-Mély-v.; Pécs, Deindol; Pécs, Éger-v.; Pécs, Mecsekszentkút, Szunyola; Pécs, Tettye.

Lymantria monacha (Linnaeus, 1758) - Bakonya, Sás-v.; Cserkút, Cserkúti-dombok; Kővágószőlős, Petőcakna; Mánfa, Nagy-Mély-v.; Pécs, Deindol; Pécs, Mecsekszentkút, Szunyola.

Euproctis chrysorrhoea (Linnaeus, 1758) - Abaliget, üdülök; Cserkút, DK; Cserkút, Szentmiklós; Mánfa, Nagy-Mély-v.; Pécs, Tettye.

Sphrageidus similis (Fuessly, 1775) (= Euproctis s., Porthesia s.) - Bükkösd, Szentdomján; Pécs, Deindol. Orgyia antiqua (Linnaeus, 1758) - Abaliget, üdülök; Orfü, Cigány-h.

Penthophera morio (Linnaeus, 1767) (= Hypogymna m.) - Bakonya, erdészház; Bükkösd, Bükkösdi-v.; Bükkösd, Szentdomján; Cserkút, DK; Hetvehely, Bükkösdi-v.

Calliteara pudibunda (Linnaeus, 1758) (= Dasychira p.) - Abaliget, Nyáras-v.; Abaliget, üdülök; Bakonya, erdészház; Bakonya, Nagy-Rege; Cserkút, Cserkúti-dombok; Cserkút, DK; Cserkút, Szentmiklós; Mánfa, Nagy-Mély-v.; Orfü, Cigány-h.; Pécs, Deindol; Pécs, Mecsekszentkút, erdészház; Pécs, Tubes. 
Arctornis l-nigrum (Müller, 1764) - Abaliget, üdülök; Bükkösd, Szentdomján; Hetvehely, Bükkösdi-v.;

Kővágótöttös, Cserma-h.; Mánfa, Nagy-Mély-v.; Pécs, Deindol.

Leucoma salicis (Linnaeus, 1758) - Cserkút, Cserkúti-dombok.

\section{Arctiinae}

Spilosoma lutea (Hufnagel, 1766) (= S. lubricipeda) - Abaliget, Nyáras-v.; Abaliget, üdülők; Bakonya, erdészház; Bükkösd, Szentdomján; Cserkút, Cserkúti-dombok; Cserkút, DK; Cserkút, Szentmiklós; Hetvehely, Bükkösdi-v.; Mánfa, Nagy-Mély-v.; Pécs, Deindol; Pécs, Mecsekszentkút, erdészház; Pécs, Tettye.

Spilosoma lubricipeda (Linnaeus, 1758) (=S. menthastri) - Abaliget, Nyáras-v.; Abaliget, üdülök; Bakonya, erdészház; Bakonya, Nagy-Rege; Bükkösd, Bükkösdi-v.; Bükkösd, Szentdomján; Cserkút, Cserkúti-dombok; Cserkút, DK; Cserkút, Szentmiklós; Hetvehely, Bükkösdi-v.; Kővágószőlős, Kajdács-dűlő; Kővágószőlős, Petőc-akna; Mánfa, Nagy-Mély-v.; Orfü, Cigány-h.; Pécs, Deindol; Pécs, Mecsekszentkút, erdészház; Pécs, Tettye; Pécs, Tubes.

Spilosoma urticae (Esper, 1789) - Cserkút, Szentmiklós; Mánfa, Nagy-Mély-v.

Hyphantria cunea (Drury, 1773) - Cserkút, Cserkúti-dombok; Cserkút, Szentmiklós; Pécs, Deindol.

Ocnogyna parasita (Hübner, 1790) - Pécs, Deindol.

Diaphora mendica (Clerck, 1759) (= Cycnia m.) - Bakonya, erdészház; Kővágótöttös, Cserma-h.; Pécs, Deindol. Diaphora luctuosa (Geyer, 1833) (=Cycnia l.) - Pécs, Deindol.

Phragmatobia fuliginosa (Linnaeus, 1758) - Abaliget, Nyáras-v.; Abaliget, üdülők; Bakonya, erdészház; Bakonya, Nagy-Rege; Bakonya, Sás-v.; Bükkösd, Szentdomján; Cserkút, Cserkúti-dombok; Cserkút, DK; Cserkút, Szentmiklós; Hetvehely, Bükkösdi-v.; Kővágószőlős, Kajdács-dűlő; Kővágótöttös, Cserma-h.; Orfü, Cigány-h.; Pécs, Deindol; Pécs, Mecsekszentkút, Szunyola; Pécs, Tettye.

Arctia caja (Linnaeus, 1758) - Abaliget, üdülök; Cserkút, Szentmiklós; Orfü, Cigány-h.; Pécs, Deindol.

Arctia villica (Linnaeus, 1758) - Abaliget, Nyáras-v.; Abaliget, üdülők; Bakonya, erdészház; Bakonya, Nagy-Rege; Cserkút, Cserkúti-dombok; Cserkút, DK; Cserkút, Szentmiklós; Mánfa, Nagy-Mély-v.; Orfü, Cigány-h.; Pécs, Árpád-tető; Pécs, Deindol; Pécs, Tettye; Pécs, Tubes.

Rhyparia purpurata (Linnaeus, 1758) - Bakonya, Nagy-Rege.

Diacrisia sannio (Linnaeus, 1758) - Abaliget, üdülök; Bakonya, erdészház; Bakonya, Nagy-Rege; Bükkösd, Bükkösdi-v.; Bükkösd, Szentdomján; Cserkút, Cserkúti-dombok; Hetvehely, Bükkösdi-v.; Kővágószőlős, Kajdács-dülő; Mánfa, Nagy-Mély-v.

Callimorpha dominula (Linnaeus, 1758) (= Panaxia d.) - Abaliget, Nyáras-v.; Abaliget, üdülök; Bükkösd, Szentdomján; Mánfa, Nagy-Mély-v.; Orfü, Cigány-h.; Pécs, Mecsekszentkút, Szunyola.

Euplagia quadripunctaria (Poda, 1761) (= Panaxia q.) - Abaliget, üdülők; Bakonya, Nagy-Rege; Bükkösd, Szentdomján; Cserkút, Cserkúti-dombok; Cserkút, DK; Cserkút, Szentmiklós; Hetvehely, Bükkösdi-v. Kővágószőlős, Kajdács-dülő; Kővágószőlős, Petőc-akna; Kővágótöttös, Cserma-h.; Mánfa, Nagy-Mély-v.; Pécs, Deindol; Pécs, Mecsekszentkút, Szunyola.

Tyria jacobaeae (Linnaeus, 1758) (= Hypocrita j.) - Cserkút, Szentmiklós; Pécs, Árpád-tető.

\section{Lithosiinae}

Spiris striata (Linnaeus, 1758) (= Coscinia s.) - Cserkút, Cserkúti-dombok.

Miltochrista miniata (Forster, 1771) - Abaliget, Nyáras-v.; Abaliget, üdülők; Bakonya, erdészház; Bakonya, NagyRege; Bakonya, Sás-v.; Bükkösd, Szentdomján; Cserkút, Cserkúti-dombok; Cserkút, DK; Cserkút, Szentmiklós; Kővágószőlős, Petőc-akna; Mánfa, Nagy-Mély-v.; Orfü, Cigány-h.; Pécs, Deindol; Pécs, Mecsekszentkút, Szunyola; Pécs, Tettye.

Cybosia mesomella (Linnaeus, 1758) - Cserkút, Szentmiklós; Mánfa, Nagy-Mély-v.

Thumatha senex (Hübner, 1808) (= Comacla s.) - Mánfa, Nagy-Mély-v.

Pelosia muscerda (Hufnagel, 1766) - Bakonya, erdészház; Cserkút, Cserkúti-dombok; Cserkút, DK; Mánfa, Nagy-Mély-v.; Pécs, Deindol; Pécs, Tettye.

Lithosia quadra (Linnaeus, 1758) - Abaliget, Nyáras-v.; Abaliget, üdülők; Bakonya, Nagy-Rege; Bükkösd, Szentdomján; Cserkút, Cserkúti-dombok; Cserkút, DK; Cserkút, Szentmiklós; Orfü, Cigány-h.; Pécs, Deindol; Pécs, Mecsekszentkút, Szunyola; Pécs, Tubes. 
Atolmis rubricollis (Linnaeus, 1758) - Pécs, Mecsekszentkút, Szunyola.

Eilema griseola (Hübner, 1803) - Abaliget, üdülők; Bükkösd, Szentdomján; Cserkút, DK; Pécs, Deindol.

Eilema depressa (Esper, [1787]) (= Eilema deplana (Esper, 1787)) - Cserkút, Szentmiklós; Pécs, Deindol.

Eilema lutarella (Linnaeus, 1758) - Cserkút, Cserkúti-dombok; Cserkút, DK; Cserkút, Szentmiklós.

Eilema lurideola (Zincken, 1817) - Abaliget, üdülők; Bakonya, erdészház; Bükkösd, Bükkösdi-v.; Cserkút, Cserkúti-dombok; Cserkút, DK; Cserkút, Szentmiklós; Kővágószőlős, Kajdács-dủlő; Mánfa, Nagy-Mély-v.; Orfü, Cigány-h.; Pécs, Deindol; Pécs, Mecsekszentkút, Szunyola; Pécs, Tettye.

Eilema caniola (Hübner, 1808) - Pécs, Deindol.

Eilema palliatella (Scopoli, 1763) - Bakonya, Nagy-Rege; Kővágószőlős, Kajdács-dủlő; Kővágószőlős, Petőc-akna; Pécs, Deindol; Pécs, Mecsekszentkút, Szunyola.

Eilema complana (Linnaeus, 1758) - Abaliget, üdülők; Bakonya, erdészház; Bakonya, Nagy-Rege; Bakonya, Sás-v.; Bükkösd, Bükkösdi-v.; Bükkösd, Szentdomján; Cserkút, Cserkúti-dombok; Cserkút, DK; Cserkút, Szentmiklós; Kővágószőlős, Petőc-akna; Kővágótöttös, Cserma-h.; Mánfa, Nagy-Mély-v.; Orfü, Cigány-h.; Pécs, Deindol; Pécs, Mecsekszentkút, Szunyola; Pécs, Tettye.

Eilema pygmaeola pallifrons (Zeller, 1847) - Cserkút, Cserkúti-dombok.

Eilema sororcula (Hufnagel, 1766) (= Sysstropha s.) - Abaliget, Nyáras-v.; Abaliget, üdülök; Bakonya, Nagy-Rege; Bakonya, Sás-v.; Bükkösd, Bükkösdi-v.; Cserkút, Cserkúti-dombok; Cserkút, DK; Cserkút, Szentmiklós; Hetvehely, Bükkösdi-v.; Kővágószőlős, Kajdács-dűlő; Kővágószőlős, Petőc-akna; Orfü, Cigány-h.; Pécs, Deindol; Pécs, Mecsekszentkút, Szunyola; Pécs, Tettye.

\section{Syntominae}

Amata phegea (Linnaeus, 1758) (= Syntomis ph.) - Abaliget, üdülök; Bakonya, erdészház; Bükkösd, Bükkösdi-v.; Cserkút, Cserkúti-dombok; Cserkút, DK; Pécs, Deindol.

Dysauxes ancilla (Linnaeus, 1767) - Cserkút, Cserkúti-dombok; Cserkút, DK; Cserkút, Szentmiklós; Mánfa, Nagy-Mély-v.; Pécs, Deindol; Pécs, Mecsekszentkút, Szunyola; Pécs, Tettye.

\section{Catocalinae}

Lygephila lusoria (Linnaeus, 1758) - Pécs, Deindol.

Lygephila viciae (Hübner, 1822) - Pécs, Deindol.

Lygephila craccae ([Denis \& Schiffermüller], 1775) - Abaliget, üdülők; Bakonya, erdészház; Bükkösd, Bükkösdi-v.; Cserkút, DK; Cserkút, Szentmiklós; Kővágószőlős, Kajdács-dűlő; Pécs, Deindol; Pécs, Mecsekszentkút, Szunyola; Pécs, Tettye.

Lygephila procax (Hübner, 1813) (= L. limosa) - Bakonya, Nagy-Rege; Pécs, Deindol; Pécs, Mecsekszentkút, erdészház; Pécs, Mecsekszentkút, Szunyola; Pécs, Tettye.

Arytrura musculus (Ménétriés, 1859) - Abaliget, üdülök; Cserkút, Cserkúti-dombok.

Euclidia glyphica (Linnaeus, 1758) - Bakonya, erdészház; Bakonya, Sás-v.; Bükkösd, Bükkösdi-v.; Cserkút, Cserkúti-dombok; Cserkút, DK; Cserkút, Szentmiklós; Kővágószőlős, Petőc-akna; Kővágótöttös, Cserma-h.; Mánfa, Nagy-Mély-v.; Pécs, Árpád-tető; Pécs, Deindol; Pécs, Éger-v.; Pécs, Mecsekszentkút, Szunyola.

Euclidia mi (Clerck, 1759) (= Callistege m.) - Cserkút, Cserkúti-dombok; Cserkút, DK; Hetvehely, Bükkösdi-v.; Pécs, Remete-rét.

Catephia alchymista ([Denis \& Schiffermüller], 1775) - Bakonya, erdészház; Cserkút, DK; Cserkút, Szentmiklós; Orfü, Cigány-h.; Pécs, Deindol; Pécs, Mecsekszentkút, Szunyola.

Minucia lunaris ([Denis \& Schiffermüller], 1775) - Bakonya, erdészház; Bakonya, Nagy-Rege; Cserkút, Cserkúti-dombok; Cserkút, DK; Cserkút, Szentmiklós; Orfü, Cigány-h.; Pécs, Árpád-tető; Pécs, Deindol; Pécs, Mecsekszentkút, Szunyola.

Dysgonia algira (Linnaeus, 1767) (= Ophiusa a.) - Abaliget, üdülök; Bakonya, Nagy-Rege; Cserkút, Cserkúti-dombok; Cserkút, DK; Cserkút, Szentmiklós; Kővágószőlős, Kajdács-dűlő; Pécs, Deindol; Pécs, Mecsekszentkút, Szunyola; Pécs, Tettye. 
Catocala fulminea (Scopoli, 1763) (= C. paranympha) - Abaliget, üdülök; Bakonya, Nagy-Rege; Bükkösd, Bükkösdi-v.; Cserkút, Cserkúti-dombok; Cserkút, DK; Cserkút, Szentmiklós; Orfü, Cigány-h.; Pécs, Deindol.

Catocala nymphagoga (Esper, 1787) - Abaliget, üdülők; Bakonya, Nagy-Rege; Bükkösd, Szentdomján;

Cserkút, DK; Cserkút, Szentmiklós; Kővágószőlős, Petőc-akna; Pécs, Deindol; Pécs, Mecsekszentkút, Szunyola; Pécs, Tettye.

Catocala hymenaea ([Denis \& Schiffermüller], 1775) - Cserkút, Cserkúti-dombok; Cserkút, DK; Cserkút, Szentmiklós; Pécs, Deindol; Pécs, Mecsekszentkút, Szunyola.

Catocala nupta (Linnaeus, 1767) - Abaliget, Nyáras-v.; Abaliget, üdülők; Bükkösd, Szentdomján; Cserkút, DK; Cserkút, Szentmiklós; Kővágószőlős, Kajdács-dűlő; Mánfa, Nagy-Mély-v.; Pécs, Mecsekszentkút, Szunyola.

Catocala electa (Vieweg, 1790) - Abaliget, üdülök.

Catocala elocata (Esper, 1787) - Abaliget, üdülök.

Catocala promissa ([Denis \& Schiffermüller], 1775) - Bakonya, Nagy-Rege.

Catocala dilecta (Hübner, 1808) - Pécs, Deindol.

Catocala sponsa (Linnaeus, 1767) - Abaliget, üdülők; Pécs, Deindol; Pécs, Mecsekszentkút, Szunyola.

\section{Euteliidae}

Eutelia adulatrix (Hübner, 1813) - Pécs, Tettye.

\section{Nolidae}

Meganola kolbi (Daniel, 1935) (= Roeselia k.) - Abaliget, Nyáras-v.; Cserkút, Cserkúti-dombok; Cserkút, DK; Pécs, Deindol; Pécs, Tettye; Pécs, Tubes.

Meganola strigula ([Denis \& Schiffermüller], 1775) (= Roeselia s.) - Bakonya, erdészház; Cserkút, Cserkútidombok; Cserkút, DK; Cserkút, Szentmiklós; Pécs, Deindol; Kővágószőlős, Petőc-akna; Mánfa, Nagy-Mély-v.; Pécs, Mecsekszentkút, Szunyola.

Meganola togatulalis (Hübner, 1798) (= Roeselia t.) - Bakonya, erdészház; Cserkút, Cserkúti-dombok; Cserkút, DK.

Meganola albula ([Denis \& Schiffermüller], 1775) (= Roeselia a.) - Abaliget, Nyáras-v.; Abaliget, üdülök; Bakonya, Nagy-Rege; Cserkút, Cserkúti-dombok; Cserkút, DK; Cserkút, Szentmiklós; Hetvehely, Bükkösdi-v.; Kővágószőlős, Kajdács-dűlő; Kővágótöttös, Cserma-h.; Mánfa, Nagy-Mély-v.; Orfü, Cigány-h.; Pécs, Deindol; Pécs, Mecsekszentkút, Szunyola.

Nola aerugula (Hübner, 1793) (= Celama centonalis) - Abaliget, Nyáras-v.; Hetvehely, Bükkösdi-v.; Kővágótöttös, Cserma-h.; Pécs, Mecsekszentkút, Szunyola.

Nola cicatricalis (Treitschke, 1835) (= Celama c.) - Abaliget, Nyáras-v.; Cserkút, Cserkúti-dombok; Cserkút,

DK; Orfü, Cigány-h.; Pécs, Deindol; Pécs, Mecsekszentkút, erdészház.

Nola confusalis (Herrich-Schäffer, 1847) (= Celama c.) - Abaliget, Nyáras-v.; Bakonya, Nagy-Rege;

Mánfa, Nagy-Mély-v.; Orfü, Cigány-h.; Pécs, Deindol; Pécs, Mecsekszentkút, Szunyola.

Nola cristatula (Hübner, 1793) (= Celama c.) - Pécs, Deindol.

Nola chlamitulalis (Hübner, 1813) (= Celama ch.) - Abaliget, Nyáras-v.; Orfü, Cigány-h.

Nola cucullatella (Linnaeus, 1758) - Bakonya, Nagy-Rege; Cserkút, Cserkúti-dombok; Cserkút, DK; Cserkút, Szentmiklós; Kővágótöttös, Cserma-h.; Pécs, Deindol.

Bena bicolorana (Fuessly, 1775) - Abaliget, üdülők; Bakonya, Nagy-Rege; Cserkút, Cserkúti-dombok; Cserkút, DK; Cserkút, Szentmiklós; Kővágószőlős, Kajdács-dűlő; Pécs, Deindol; Pécs, Mecsekszentkút, Szunyola.

Pseudoips prasinana (Linnaeus, 1758) (= Hylophila fagana) - Abaliget, Nyáras-v.; Abaliget, üdülők; Bakonya, erdészház; Bakonya, Nagy-Rege; Cserkút, Cserkúti-dombok; Cserkút, DK; Cserkút, Szentmiklós; Hetvehely, Bükkösdi-v.; Kővágószőlős, Petőc-akna; Kővágótöttös, Cserma-h.; Mánfa, Nagy-Mély-v.; Orfü, Cigány-h.; Pécs, Deindol; Pécs, Mecsekszentkút, erdészház; Pécs, Mecsekszentkút, Szunyola.

Earias clorana (Linnaeus, 1761) - Abaliget, üdülök; Bükkösd, Bükkösdi-v.; Cserkút, Cserkúti-dombok; Cserkút, DK; Hetvehely, Bükkösdi-v.; Pécs, Deindol. 
Earias vernana (Fabricius, 1787) - Cserkút, DK; Pécs, Mecsekszentkút, Szunyola.

Nycteola revayana (Scopoli, 1772) - Bakonya, Nagy-Rege; Cserkút, DK; Mánfa, Nagy-Mély-v.; Orfü, Cigány-h.

Nycteola asiatica (Krulikovsky, 1904) - Cserkút, DK; Pécs, Deindol.

\section{Noctuidae}

\section{Plusiinae}

Abrostola tripartita (Hufnagel, 1766) (= triplasia régen) - Abaliget, Nyáras-v.; Abaliget, üdülők; Bakonya, Nagy-Rege; Cserkút, Cserkúti-dombok; Cserkút, DK; Cserkút, Szentmiklós; Kővágószőlős, Kajdács-dűlő; Pécs, Deindol; Pécs, Tettye.

Abrostola asclepiadis ([Denis \& Schiffermüller], 1775) - Bakonya, erdészház; Bakonya, Nagy-Rege; Cserkút, Cserkúti-dombok; Cserkút, DK; Cserkút, Szentmiklós; Mánfa, Nagy-Mély-v.; Pécs, Deindol; Pécs, Mecsekszentkút, erdészház; Pécs, Tettye; Pécs, Tubes.

Abrostola triplasia (Linnaeus, 1758) (= trigemina) - Abaliget, üdülők; Bakonya, erdészház; Bakonya, Nagy-Rege; Bakonya, Sás-v.; Bükkösd, Bükkösdi-v.; Bükkösd, Szentdomján; Cserkút, Cserkúti-dombok; Cserkút, DK; Cserkút, Szentmiklós; Kővágószőlős, Kajdács-dűlő; Mánfa, Nagy-Mély-v.; Orfü, Cigány-h.; Pécs, Deindol; Pécs, Mecsekszentkút, erdészház; Pécs, Mecsekszentkút, Szunyola; Pécs, Tettye.

Trichoplusia ni (Hübner, 1803) - Pécs, Deindol.

Macdunnoughia confusa (Stephens, 1850) - Abaliget, Nyáras-v.; Abaliget, üdülők; Bakonya, erdészház; Bükkösd, Bükkösdi-v.; Bükkösd, Szentdomján; Cserkút, Cserkúti-dombok; Cserkút, DK; Cserkút, Szentmiklós; Kővágószőlős, Kajdács-dúlö; Kővágótöttös, Cserma-h.; Mánfa, Nagy-Mély-v.; Pécs, Deindol; Pécs, Mecsekszentkút, Szunyola; Pécs, Tettye.

Diachrysia chryson (Esper, 1789) - Abaliget, üdülők.

Diachrysia chrysitis (Linnaeus, 1758) (= Plusia ch.) - Abaliget, üdülők; Bakonya, erdészház; Bakonya, Nagy-Rege; Bükkösd, Bükkösdi-v.; Bükkösd, Szentdomján; Cserkút, DK; Cserkút, Szentmiklós; Hetvehely, Bükkösdi-v.; Kővágószőlős, Kajdács-dűlő; Mánfa, Nagy-Mély-v.; Orfü, Cigány-h.; Pécs, Árpád-tető; Pécs, Deindol; Pécs, Mecsekszentkút, erdészház; Pécs, Tubes.

Diachrysia stenochrysis (Warren, 1913) - Abaliget, Nyáras-v.; Abaliget, üdülők.

Autographa gamma (Linnaeus, 1758) - Abaliget, Nyáras-v.; Abaliget, üdülők; Bakonya, erdészház; Bakonya, Nagy-Rege; Bakonya, Sás-v.; Bükkösd, Bükkösdi-v.; Bükkösd, Szentdomján; Cserkút, Cserkútidombok; Cserkút, DK; Cserkút, Szentmiklós; Kővágószőlős, Kajdács-dűlő; Kővágószőlős, Petőc-akna; Kővágótöttös, Cserma-h.; Mánfa, Nagy-Mély-v.; Pécs, Deindol; Pécs, Mecsekszentkút, Szunyola; Pécs, Tettye; Pécs, Tubes.

Autographa jota (Linnaeus, 1758) - Abaliget, Nyáras-v.; Mánfa, Nagy-Mély-v.; Orfü, Cigány-h.; Pécs, Deindol; Pécs, Mecsekszentkút, Szunyola; Pécs, Tubes.

Plusia festucae (Linnaeus, 1758) - Cserkút, DK.

\section{Eustrotiinae}

Protodeltote pygarga (Hufnagel, 1766) (= Jaspidia p.) - Abaliget, Nyáras-v.; Abaliget, üdülök; Bakonya, erdészház; Bakonya, Nagy-Rege; Bakonya, Sás-v.; Bükkösd, Bükkösdi-v.; Bükkösd, Szentdomján; Cserkút, Cserkúti-dombok; Cserkút, DK; Cserkút, Szentmiklós; Hetvehely, Bükkösdi-v.; Kővágótöttös, Cserma-h.; Mánfa, Nagy-Mély-v.; Orfü, Cigány-h.; Pécs, Deindol; Pécs, Mecsekszentkút, erdészház; Pécs, Mecsekszentkút, Szunyola; Pécs, Tettye; Pécs, Tubes.

Deltote deceptoria (Scopoli, 1763) (= Jaspidia d.) Pécs, Tubes.

Deltote bankiana (Fabricius, 1775) (= Eustrotia b.) - Abaliget, Nyáras-v.; Bakonya, erdészház; Bakonya, Nagy-Rege; Bükkösd, Bükkösdi-v.; Cserkút, Cserkúti-dombok; Cserkút, DK; Hetvehely, Bükkösdi-v.; Kövágószőlős, Petöc-akna.

\section{Acontiinae}

Acontia lucida (Hufnagel, 1766) - Cserkút, Szentmiklós; Pécs, Deindol. 
Acontia trabealis (Scopoli, 1763) (=Emmelia t.) - Abaliget, üdülők; Bakonya, erdészház; Bakonya, NagyRege; Bükkösd, Bükkösdi-v.; Bükkösd, Szentdomján; Cserkút, Cserkúti-dombok; Cserkút, DK; Cserkút, Szentmiklós; Kővágószőlős, Kajdács-dűlő; Kővágószőlős, Petőc-akna; Pécs, Deindol; Pécs, Mecsekszentkút, Szunyola; Pécs, Tettye.

Aedia funesta (Esper, 1786) - Abaliget, üdülök; Bakonya, erdészház; Bükkösd, Bükkösdi-v.; Bükkösd, Szentdomján; Cserkút, DK; Cserkút, Szentmiklós; Orfü, Cigány-h.; Pécs, Deindol; Pécs, Mecsekszentkút, Szunyola; Pécs, Tettye.

Aedia leucomelas (Linnaeus, 1758) - Abaliget, üdülök; Bakonya, Nagy-Rege; Cserkút, Cserkúti-dombok; Kővágótöttös, Cserma-h.; Pécs, Deindol.

\section{Pantheinae}

Colocasia coryli (Linnaeus, 1758) - Abaliget, Nyáras-v.; Abaliget, üdülők; Bakonya, erdészház; Bakonya, Nagy-Rege; Bükkösd, Bükkösdi-v.; Cserkút, Cserkúti-dombok; Cserkút, DK; Cserkút, Szentmiklós; Hetvehely, Bükkösdi-v.; Kővágószőlős, Petőc-akna; Mánfa, Nagy-Mély-v.; Orfü, Cigány-h.; Pécs, Árpád-tető; Pécs, Deindol; Pécs, Éger-v.; Pécs, Mecsekszentkút, erdészház; Pécs, Mecsekszentkút, Szunyola; Pécs, Tettye.

\section{Dilobinae}

Diloba caeruleocephala (Linnaeus, 1758) - Abaliget, üdülök; Cserkút, DK; Cserkút, Szentmiklós; Cserkút, vízmű környék; Kővágószőlős, Kajdács-dűlő; Mánfa, Nagy-Mély-v.; Orfü, Cigány-h.; Pécs, Deindol; Pécs, Tettye.

\section{Acronictinae}

Craniophora ligustri ([Denis \& Schiffermüller], 1775) - Abaliget, üdülők; Bakonya, erdészház; Bakonya, Nagy-Rege; Bükkösd, Szentdomján; Cserkút, Cserkúti-dombok; Cserkút, DK; Cserkút, Szentmiklós; Hetvehely, Bükkösdi-v.; Kővágószőlős, Petőc-akna; Kővágótöttös, Cserma-h.; Mánfa, Nagy-Mély-v.; Orfü, Cigány-h.; Pécs, Deindol; Pécs, Mecsekszentkút, erdészház; Pécs, Mecsekszentkút, Szunyola; Pécs, Tettye; Pécs, Tubes.

Moma alpium (Osbeck, 1778) - Bakonya, Nagy-Rege; Cserkút, Cserkúti-dombok.

Simyra nervosa ([Denis \& Schiffermüller], 1775) - Cserkút, DK.

Acronicta alni (Linnaeus, 1767) (Acronicta = Apatele) - Bakonya, Nagy-Rege; Bükkösd, Bükkösdi-v.;

Cserkút, Cserkúti-dombok; Kővágószőlős, Petőc-akna; Pécs, Deindol; Pécs, Mecsekszentkút, erdészház; Pécs,

Mecsekszentkút, Szunyola.

Acronicta cuspis (Hübner, 1813) - Abaliget, üdülők.

Acronicta tridens ([Denis \& Schiffermüller], 1775) - Cserkút, Cserkúti-dombok; Cserkút, DK; Cserkút, Szentmiklós; Kővágószőlős, Kajdács-dűlő; Mánfa, Nagy-Mély-v.; Pécs, Deindol; Pécs, Mecsekszentkút, erdészház; Pécs, Mecsekszentkút, Szunyola; Pécs, Tettye.

Acronicta psi (Linnaeus, 1758) - Cserkút, Cserkúti-dombok; Cserkút, DK; Cserkút, Szentmiklós; Pécs, Deindol.

Acronicta strigosa ([Denis \& Schiffermüller], 1775) - Bakonya, Nagy-Rege; Hetvehely, Bükkösdi-v. Acronicta auricoma ([Denis \& Schiffermüller], 1775) - Abaliget, Nyáras-v.; Bakonya, Nagy-Rege; Bükkösd, Bükkösdi-v.; Cserkút, Cserkúti-dombok; Cserkút, DK; Kővágószőlős, Petőc-akna; Pécs, Deindol. Acronicta euphorbiae ([Denis \& Schiffermüller], 1775) - Bakonya, erdészház; Cserkút, Cserkúti-dombok; Cserkút, DK; Cserkút, Szentmiklós.

Acronicta rumicis (Linnaeus, 1758) - Abaliget, Nyáras-v.; Abaliget, üdülők; Bakonya, erdészház; Bükkösd,

Bükkösdi-v.; Cserkút, Cserkúti-dombok; Cserkút, DK; Cserkút, Szentmiklós; Hetvehely, Bükkösdi-v.; Kővágószőlős, Kajdács-dűlő; Pécs, Deindol; Pécs, Mecsekszentkút, erdészház; Pécs, Mecsekszentkút, Szunyola.

Acronicta aceris (Linnaeus, 1758) - Abaliget, üdülők; Bakonya, Nagy-Rege; Cserkút, Cserkúti-dombok;

Kővágószőlős, Petőc-akna; Pécs, Deindol; Pécs, Mecsekszentkút, Szunyola.

Acronicta leporina (Linnaeus, 1758) - Abaliget, üdülök. 
Acronicta megacephala ([Denis \& Schiffermüller], 1775) - Bükkösd, Bükkösdi-v.; Cserkút, Cserkútidombok; Cserkút, Szentmiklós; Pécs, Deindol; Pécs, Mecsekszentkút, Szunyola.

\section{Metoponiinae}

Panemeria tenebrata (Scopoli, 1763) - Bükkösd, Bükkösdi-v.; Bükkösd, Szentdomján; Cserkút, Cserkútidombok; Hetvehely, Bükkösdi-v.; Kővágószőlős, Kajdács-dűlő; Pécs, Árpád-tető.

Tyta luctuosa ([Denis \& Schiffermüller], 1775) - Abaliget, üdülök; Bakonya, erdészház; Bakonya, Nagy-Rege; Bükkösd, Bükkösdi-v.; Bükkösd, Szentdomján; Cserkút, Cserkúti-dombok; Cserkút, DK; Cserkút, Szentmiklós; Hetvehely, Bükkösdi-v.; Kővágószőlős, Kajdács-dűlő; Pécs, Deindol; Pécs, Mecsekszentkút, Szunyola; Pécs, Tettye.

\section{Cuculliinae}

Shargacucullia lychnitis (Rambur, 1833) - Bakonya, Nagy-Rege; Cserkút, DK; Kővágószőlős, Kajdácsdülő; Orfü, Cigány-h.

Shargacucullia gozmanyi G. \& L. Ronkay, 1994 - Cserkút, Cserkúti-dombok.

Shargacucullia verbasci (Linnaeus, 1758) - Cserkút, Cserkúti-dombok; Pécs, Tettye.

Shargacucullia prenanthis (Boisduval, 1840) - Pécs, Deindol; Pécs, Mecsekszentkút, Szunyola.

Cucullia lactucae ([Denis \& Schiffermüller], 1775) - Abaliget, Nyáras-v.; Cserkút, DK; Cserkút, Szentmiklós.

Cucullia umbratica (Linnaeus, 1758) - Cserkút, DK; Pécs, Deindol.

Cucullia chamomillae ([Denis \& Schiffermüller], 1775) - Pécs, Deindol.

\section{Oncocnemidinae}

Calophasia lunula (Hufnagel, 1766) - Abaliget, üdülök; Bakonya, Nagy-Rege; Cserkút, Cserkúti-dombok; Cserkút, DK; Cserkút, Szentmiklós; Pécs, Deindol; Pécs, Tettye.

Calophasia platyptera (Esper, 1788) - Cserkút, Szentmiklós; Pécs, Deindol.

Calophasia opalina (Esper, 1793) (= casta) - Pécs, Deindol.

\section{Amphipyrinae}

Amphipyra pyramidea (Linnaeus, 1758) - Abaliget, üdülők; Bakonya, erdészház; Cserkút, Cserkútidombok; Cserkút, DK; Cserkút, Szentmiklós; Kővágószőlős, Kajdács-dűlő; Kővágószőlős, Petőc-akna; Mánfa, Nagy-Mély-v.; Pécs, Deindol; Pécs, Éger-v.; Pécs, Mecsekszentkút, Szunyola; Pécs, Tettye.

Amphipyra berbera svensoni (Fletcher, 1968) - Abaliget, üdülők; Pécs, Deindol.

Amphipyra tragopogonis (Clerck, 1759) - Abaliget, üdülők; Cserkút, Cserkúti-dombok; Cserkút, DK; Cserkút, Szentmiklós; Kővágószőlős, Kajdács-dűlő; Mánfa, Nagy-Mély-v.; Pécs, Deindol; Pécs, Tettye.

Amphipyra livida ([Denis \& Schiffermüller], 1775) - Cserkút, Cserkúti-dombok; Cserkút, DK; Cserkút, Szentmiklós; Kővágószőlős, Kajdács-dűlő; Pécs, Deindol.

\section{Psaphidinae}

Asteroscopus sphinx (Hufnagel, 1766) (= Brachionycha s.) - Bakonya, erdészház; Cserkút, DK; Cserkút, Szentmiklós; Orfü, Cigány-h.; Pécs, Deindol; Pécs, Tettye.

Brachionycha nubeculosa (Esper, 1785) - Abaliget, üdülök; Bakonya, erdészház; Bükkösd, Bükkösdi-v.; Mánfa, Nagy-Mély-v.; Orfü, Cigány-h.; Pécs, Árpád-tető; Pécs, Deindol.

Valeria oleagina ([Denis \& Schiffermüller], 1775) - Abaliget, üdülők; Bakonya, erdészház; Bükkösd, Bükkösdi-v.; Bükkösd, Szentdomján; Cserkút, Cserkúti-dombok; Cserkút, DK; Kővágószőlős, Kajdács-dűlő; Kővágótöttös, Bicsérdi-vízf.; Pécs, Deindol; Pécs, Mecsekszentkút, Szunyola; Pécs, Tettye.

Lamprosticta culta ([Denis \& Schiffermüller], 1775) - Bakonya, Nagy-Rege; Cserkút, DK; Cserkút, Szentmiklós; Pécs, Deindol; Pécs, Mecsekszentkút, Szunyola.

Meganephria bimaculosa (Linnaeus, 1767) - Cserkút, Cserkúti-dombok; Kővágószőlős, Kajdács-dűlő; Pécs, Deindol. 
Allophyes oxyacanthae (Linnaeus, 1758) - Abaliget, üdülők; Bakonya, erdészház; Cserkút, DK; Cserkút, Szentmiklós; Cserkút, vízmű környék; Kővágószőlős, Kajdács-dűlő; Kővágószőlős, Petőc-akna; Mánfa, Nagy-Mély-v.; Orfü, Cigány-h.; Pécs, Deindol; Pécs, Tettye.

\section{Condicinae}

Acosmetia caliginosa (Hübner, 1813) - Cserkút, Szentmiklós.

Eucarta amethystina (Hübner, 1803) (= Telesilla a.) - Abaliget, Nyáras-v.; Abaliget, üdülök; Bakonya, erdészház; Bükkösd, Bükkösdi-v.; Bükkösd, Szentdomján; Cserkút, Cserkúti-dombok; Bakonya, Nagy-Rege; Bakonya, Sás-v.; Mánfa, Nagy-Mély-v.; Pécs, Mecsekszentkút, erdészház.

Eucarta virgo (Treitschke, 1835) (= Callagonia v.) - Abaliget, Nyáras-v.; Bakonya, erdészház; Bükkösd, Szentdomján; Cserkút, Cserkúti-dombok; Cserkút, DK; Pécs, Mecsekszentkút, Szunyola.

\section{Heliothinae}

Periphanes delphinii (Linnaeus, 1758) - Cserkút, Szentmiklós; Pécs, Tettye.

Pyrrhia umbra (Hufnagel, 1766) - Abaliget, üdülők; Bakonya, Nagy-Rege; Cserkút, Cserkúti-dombok; Cserkút, DK; Cserkút, Szentmiklós; Kővágószőlős, Petőc-akna; Mánfa, Nagy-Mély-v.; Pécs, Deindol; Pécs, Tettye.

Protoschinia scutosa ([Denis \& Schiffermüller], 1775) (= Melicleptria s.) - Orfü, Cigány-h.

Heliothis nubigera Herrich-Schäffer, 1851 - Abaliget, üdülők; Cserkút, DK; Pécs, Deindol.

Heliothis peltigera ([Denis \& Schiffermüller], 1775) - Pécs, Deindol.

Heliothis viriplaca (Hufnagel, 1766) (= dipsacea (Linnaeus, 1767)) - Bakonya, Nagy-Rege; Cserkút,

Cserkúti-dombok; Cserkút, DK; Cserkút, Szentmiklós; Kővágószőlős, Kajdács-dűlő; Pécs, Tettye.

Helicoverpa armigera (Hübner, 1808) (= Heliothis a.) - Abaliget, üdülök; Bakonya, Nagy-Rege; Cserkút, Cserkúti-dombok; Kővágószőlős, Kajdács-dülő; Kővágótöttös, Cserma-h.; Orfü, Cigány-h.; Pécs, Deindol; Pécs, Mecsekszentkút, Szunyola.

\section{Bryophilinae}

Cryphia fraudatricula (Hübner, 1803) (= Bryophila palliola) - Pécs, Deindol; Pécs, Tettye.

Cryphia algae (Fabricius, 1775) (= Bryophila a.) - Bükkösd, Szentdomján; Cserkút, Cserkúti-dombok; Cserkút, DK; Cserkút, Szentmiklós; Kővágószőlős, Kajdács-dűlő; Pécs, Deindol; Pécs, Mecsekszentkút, Szunyola.

Bryophila raptricula ([Denis \& Schiffermüller], 1775) (= Bryophila $r$.) - Cserkút, DK.

Bryophila felina (Eversmann, 1852) (= B. raptricula) - Abaliget, üdülők; Pécs, Deindol.

\section{Eriopinae}

Callopistria juventina (Stoll, 1782) - Kővágószőlős, Petőc-akna.

\section{Xyleninae}

Pseudeustrotia candidula ([Denis \& Schiffermüller], 1775) (= Deltote, Eustrotia c.) - Abaliget, üdülök. Bakonya, erdészház; Bakonya, Nagy-Rege; Cserkút, Cserkúti-dombok; Cserkút, DK; Cserkút, Szentmiklós; Kővágószőlős, Kajdács-dűlő; Pécs, Deindol.

Spodoptera exigua (Hübner, 1808) - Bakonya, Nagy-Rege; Pécs, Deindol.

Elaphria venustula (Hübner, 1790) (= Agrotis v., Hapalotis v.) - Abaliget, Nyáras-v.; Bakonya, erdészház.

Bakonya, Nagy-Rege; Bakonya, Sás-v.; Bükkösd, Bükkösdi-v.; Cserkút, Cserkúti-dombok; Cserkút, Szentmiklós; Kővágótöttös, Cserma-h.; Orfü, Cigány-h.; Pécs, Deindol.

Caradrina morpheus (Hufnagel, 1766) - Bakonya, erdészház; Bakonya, Nagy-Rege; Bükkösd, Bükkösdi-v.; Cserkút, Cserkúti-dombok; Cserkút, DK; Cserkút, Szentmiklós; Kővágószőlős, Kajdács-dűlő; Kővágószőlős, Petőc-akna; Pécs, Deindol.

Caradrina kadenii (Freyer, 1836) - Cserkút, DK; Cserkút, Szentmiklós; Kővágószőlős, Kajdács-dülő; Pécs,

Deindol; Pécs, Tettye.

Caradrina aspersa (Rambur, 1834) - Abaliget, üdülök; Pécs, Deindol; Pécs, Tettye. 
Caradrina clavipalpis (Scopoli, 1763) - Bakonya, erdészház; Cserkút, DK; Cserkút, Szentmiklós; Pécs, Deindol.

Hoplodrina octogenaria (Goeze, 1781) (= H. alsines (Brahm, 1891)) - Abaliget, üdülök; Bakonya, NagyRege; Bükkösd, Bükkösdi-v.; Cserkút, Cserkúti-dombok; Cserkút, DK; Cserkút, Szentmiklós; Kővágószőlős, Kajdács-dűlő; Mánfa, Nagy-Mély-v.; Pécs, Mecsekszentkút, Szunyola; Pécs, Deindol; Pécs, Tettye; Pécs, Tubes.

Hoplodrina blanda ([Denis \& Schiffermüller], 1775) - Abaliget, üdülök; Bakonya, Nagy-Rege; Cserkút, Cserkúti-dombok; Cserkút, DK; Cserkút, Szentmiklós; Kővágószőlős, Petőc-akna; Pécs, Deindol.

Hoplodrina superstes (Ochsenheimer, 1816) - Pécs, Deindol; Pécs, Tettye.

Hoplodrina respersa ([Denis \& Schiffermüller], 1775) - Abaliget, üdülök; Cserkút, Cserkúti-dombok; Cserkút, DK; Cserkút, Szentmiklós; Pécs, Deindol; Pécs, Tettye.

Hoplodrina ambigua ([Denis \& Schiffermüller], 1775) - Abaliget, Nyáras-v.; Abaliget, üdülök; Bakonya, erdészház; Bakonya, Nagy-Rege; Bükkösd, Bükkösdi-v.; Bükkösd, Szentdomján; Cserkút, Cserkúti-dombok; Cserkút, DK; Cserkút, Szentmiklós; Kővágószőlős, Kajdács-dűlő; Kővágótöttös, Cserma-h.; Mánfa, NagyMély-v.; Pécs, Deindol; Pécs, Mecsekszentkút, erdészház; Pécs, Tettye; Pécs, Tubes.

Charanyca trigrammica (Hufnagel, 1766) (= Meristis t.) - Abaliget, Nyáras-v.; Abaliget, üdülők; Bakonya, erdészház; Bakonya, Nagy-Rege; Bükkösd, Bükkösdi-v.; Cserkút, Cserkúti-dombok; Cserkút, DK; Cserkút, Szentmiklós; Hetvehely, Bükkösdi-v.; Kővágószőlős, Kajdács-dűlő; Mánfa, Nagy-Mély-v.; Pécs, Deindol; Pécs, Tettye.

Rusina ferruginea (Esper, 1785) - Abaliget, üdülők; Bakonya, Nagy-Rege; Bakonya, Sás-v.; Cserkút, Cserkúti-dombok; Cserkút, DK; Cserkút, Szentmiklós; Kővágószőlős, Kajdács-dűlő; Mánfa, Nagy-Mély-v.; Pécs, Deindol; Pécs, Mecsekszentkút, Szunyola; Pécs, Tettye; Pécs, Tubes.

Athetis gluteosa (Treitschke, 1835) - Cserkút, Cserkúti-dombok; Cserkút, Szentmiklós; Pécs, Deindol.

Athetis furvula (Hübner, 1808) - Pécs, Deindol.

Athetis lepigone (Möschler, 1860) - Bakonya, Nagy-Rege.

Dypterygia scabriuscula (Linnaeus, 1758) - Abaliget, üdülők; Cserkút, Cserkúti-dombok; Cserkút, DK; Cserkút, Szentmiklós; Kővágószőlős, Kajdács-dűlő; Kővágószőlős, Petőc-akna; Pécs, Deindol; Pécs, Tettye.

Trachea atriplicis (Linnaeus, 1758) - Abaliget, üdülők; Bakonya, erdészház; Bükkösd, Bükkösdi-v.; Cserkút, Cserkúti-dombok; Cserkút, DK; Cserkút, Szentmiklós; Kővágószőlős, Kajdács-dűlő; Kővágószőlős, Petőc-akna; Mánfa, Nagy-Mély-v.; Pécs, Deindol; Pécs, Mecsekszentkút, erdészház.

Polyphaenis sericata (Esper, 1787) (=viridis (Villers, 1789)) - Abaliget, üdülők; Bakonya, Nagy-Rege; Bakonya, Sás-v.; Cserkút, Cserkúti-dombok; Kővágószőlős, Kajdács-dűlő; Pécs, Deindol; Pécs, Mecsekszentkút, Szunyola.

Thalpophila matura (Hufnagel, 1766) - Abaliget, üdülők; Bakonya, Nagy-Rege; Hetvehely, Bükkösdi-v.; Kővágószőlős, Kajdács-dűlő; Kővágótöttös, Cserma-h.; Pécs, Deindol; Pécs, Mecsekszentkút, Szunyola.

Actinotia polyodon (Clerck, 1759) - Abaliget, üdülök; Cserkút, Cserkúti-dombok; Cserkút, DK; Cserkút, Szentmiklós; Pécs, Deindol.

Chloantha hyperici ([Denis \& Schiffermüller], 1775) (=Actinotia h.) - Cserkút, Cserkúti-dombok; Cserkút, DK; Cserkút, Szentmiklós; Kővágószőlős, Kajdács-dülő; Pécs, Deindol; Pécs, Tettye.

Phlogophora meticulosa (Linnaeus, 1758) - Abaliget, üdülök; Bakonya, erdészház; Cserkút, Cserkútidombok; Cserkút, DK; Cserkút, Szentmiklós; Kővágószőlős, Kajdács-dűlő; Mánfa, Nagy-Mély-v.; Pécs, Deindol; Pécs, Tettye.

Euplexia lucipara (Linnaeus, 1758) - Abaliget, Nyáras-v.; Abaliget, üdülők; Bakonya, Nagy-Rege; Bakonya, Sás-v.; Bükkösd, Bükkösdi-v.; Bükkösd, Szentdomján; Cserkút, Cserkúti-dombok; Cserkút, DK; Cserkút, Szentmiklós; Hetvehely, Bükkösdi-v.; Mánfa, Nagy-Mély-v.; Orfü, Cigány-h.; Pécs, Deindol; Pécs, Mecsekszentkút, erdészház; Pécs, Tettye; Pécs, Tubes.

Auchmis detersa (Esper, 1787) - Abaliget, üdülők.

Calamia tridens (Hufnagel, 1766) - Cserkút, Cserkúti-dombok; Cserkút, DK; Cserkút, Szentmiklós.

Gortyna flavago ([Denis \& Schiffermüller], 1775) - Abaliget, üdülők; Cserkút, Cserkúti-dombok; Cserkút, Szentmiklós; Hetvehely, Bükkösdi-v.; Kővágószőlős, Kajdács-dülő; Pécs, Mecsekszentkút, Szunyola. 
Hydraecia micacea (Esper, 1789) - Hetvehely, Bükkösdi-v.

Hydraecia petasitis Doubleday, 1847 - Mánfa, Nagy-Mély-v.

Amphipoea oculea (Linnaeus, 1761) - Abaliget, üdülők; Bakonya, Nagy-Rege; Cserkút, Cserkúti-dombok;

Cserkút, DK; Cserkút, Szentmiklós.

Luperina testacea ([Denis \& Schiffermüller], 1775) - Bakonya, erdészház; Bakonya, Nagy-Rege; Cserkút,

Cserkúti-dombok; Cserkút, DK; Cserkút, Szentmiklós; Kővágószőlős, Kajdács-dűlő; Pécs, Deindol; Pécs, Tettye.

Rhizedra lutosa (Hübner, 1803) - Kővágószőlős, Kajdács-dűlő.

Nonagria typhae (Thunberg, 1784) - Abaliget, üdülők.

Denticucullus pygmina (Haworth, 1809) (= Chortodes, Arenostola p.) - Pécs, Deindol.

Photedes fluxa (Hübner, 1809) (= Chortodes f., Arenostola f.) - Cserkút, DK; Cserkút, Szentmiklós; Hetvehely, Bükkösdi-v.; Pécs, Deindol; Pécs, Mecsekszentkút, Szunyola; Pécs, Tettye.

Photedes minima (Haworth, 1809) - Mánfa, Nagy-Mély-v.; Pécs, Deindol; Pécs, Mecsekszentkút, Szunyola;

Photedes extrema (Hübner, 1809) (= Chortodes e., Arenostola e.) - Bakonya, erdészház; Bükkösd, Bükkösdi-v.; Cserkút, DK; Cserkút, Szentmiklós; Hetvehely, Bükkösdi-v.; Kővágószőlős, Kajdács-dűlő; Pécs, Deindol.

Globia sparganii (Esper, 1790) (= Archanara s.) - Pécs, Mecsekszentkút, Szunyola.

Pabulatrix pabulatricula (Brahm, 1791) (=Eremobina p., Apamea p.) - Pécs, Mecsekszentkút, Szunyola. Apamea monoglypha (Hufnagel, 1766) - Bakonya, erdészház; Cserkút, DK; Cserkút, Szentmiklós; Mánfa,

Nagy-Mély-v.; Pécs, Deindol; Pécs, Mecsekszentkút, Szunyola.

Apamea lithoxylaea ([Denis \& Schiffermüller], 1775) - Cserkút, Cserkúti-dombok; Cserkút, DK; Cserkút,

Szentmiklós; Pécs, Deindol; Pécs, Mecsekszentkút, Szunyola; Pécs, Tettye.

Apamea remissa (Hübner, 1809) - Bakonya, Nagy-Rege; Mánfa, Nagy-Mély-v.; Orfü, Cigány-h.; Pécs, Mecsekszentkút, Szunyola.

Apamea sordens (Hufnagel, 1766) - Bakonya, erdészház; Bakonya, Nagy-Rege; Cserkút, DK; Cserkút, Szentmiklós; Kővágószőlős, Kajdács-dűlő; Mánfa, Nagy-Mély-v.; Pécs, Deindol.

Apamea illyria Freyer, 1846 - Mánfa, Nagy-Mély-v.; Pécs, Deindol.

Loscopia scolopacina (Esper, 1788) (= Apamea s.) - Abaliget, üdülök; Cserkút, Cserkúti-dombok; Cserkút,

DK; Mánfa, Nagy-Mély-v.; Pécs, Deindol; Pécs, Mecsekszentkút, Szunyola.

Mesapamea secalis (Linnaeus, 1758) - Abaliget, üdülők; Bakonya, Nagy-Rege; Cserkút, Cserkúti-dombok;

Cserkút, DK; Cserkút, Szentmiklós; Kővágószőlős, Kajdács-dűlő; Kővágótöttös, Cserma-h.; Mánfa, Nagy-

Mély-v.; Pécs, Deindol; Pécs, Mecsekszentkút, Szunyola.

Mesoligia furuncula ([Denis \& Schiffermüller], 1775) - Bakonya, erdészház; Cserkút, Cserkúti-dombok;

Cserkút, DK; Cserkút, Szentmiklós; Kővágószőlős, Kajdács-dűlő; Kővágószőlős, Petőc-akna; Kővágótöttös,

Cserma-h.; Pécs, Deindol; Pécs, Mecsekszentkút, Szunyola.

Oligia strigilis (Linnaeus, 1758) - Abaliget, Nyáras-v.; Abaliget, üdülők; Bakonya, erdészház; Bakonya, Nagy-Rege; Bükkösd, Bükkösdi-v.; Bükkösd, Szentdomján; Cserkút, Cserkúti-dombok; Cserkút, DK; Cserkút, Szentmiklós; Hetvehely, Bükkösdi-v.; Kővágószőlős, Kajdács-dülő; Mánfa, Nagy-Mély-v.; Orfü, Cigány-h.; Pécs, Deindol; Pécs, Mecsekszentkút, Szunyola; Pécs, Tettye; Pécs, Tubes.

Oligia latruncula ([Denis \& Schiffermüller], 1775) - Abaliget, Nyáras-v.; Abaliget, üdülök; Bakonya, erdészház; Bakonya, Nagy-Rege; Bükkösd, Bükkösdi-v.; Bükkösd, Szentdomján; Cserkút, Cserkúti-dombok; Cserkút, DK; Cserkút, Szentmiklós; Kővágószőlős, Kajdács-dülő; Mánfa, Nagy-Mély-v.; Orfü, Cigány-h.; Pécs, Deindol; Pécs, Mecsekszentkút, Szunyola; Pécs, Tettye; Pécs, Tubes.

Oligia versicolor (Borkhausen, 1792) - Mánfa, Nagy-Mély-v.; Pécs, Tettye.

Episema glaucina (Esper, 1789) - Cserkút, DK.

Episema tersa ([Denis \& Schiffermüller], 1775) (= trimacula) - Cserkút, DK; Pécs, Deindol.

Cleoceris scoriacea (Esper, 1789) - Kővágószőlős, Kajdács-dűlő; Pécs, Deindol.

Ipimorpha retusa (Linnaeus, 1761) - Abaliget, üdülők; Kővágószőlős, Kajdács-dűlő.

Ipimorpha subtusa ([Denis \& Schiffermüller], 1775) - Cserkút, Szentmiklós.

Cosmia diffinis (Linnaeus, 1767) - Kővágószőlős, Kajdács-dűlő. 
Cosmia affinis (Linnaeus, 1767) - Bükkösd, Szentdomján; Cserkút, Cserkúti-dombok; Cserkút, DK; Kővágószőlős, Kajdács-dülő; Pécs, Tettye.

Cosmia trapezina (Linnaeus, 1758) - Abaliget, üdülök; Bakonya, Sás-v.; Bükkösd, Bükkösdi-v.; Cserkút, DK; Cserkút, Szentmiklós; Kővágószőlős, Kajdács-dűlő; Mánfa, Nagy-Mély-v.; Pécs, Mecsekszentkút, Szunyola; Pécs, Deindol; Pécs, Tettye.

Cosmia pyralina ([Denis \& Schiffermüller], 1775) - Abaliget, üdülők; Cserkút, DK; Mánfa, Nagy-Mély-v.; Pécs, Deindol.

Tiliacea citrago (Linnaeus, 1758) (= Cirrhia c., Xanthia c.) - Abaliget, üdülők; Bakonya, erdészház; Bakonya, Nagy-Rege; Cserkút, DK; Cserkút, Szentmiklós; Kővágószőlős, Kajdács-dűlő; Kővágószőlős, Petőc-akna; Kővágótöttös, Cserma-h.; Mánfa, Nagy-Mély-v.; Orfü, Cigány-h.; Pécs, Deindol; Pécs, Mecsekszentkút, Szunyola; Pécs, Tettye.

Tiliacea aurago ([Denis \& Schiffermüller], 1775) (=Xanthia a.) - Abaliget, üdülők; Bakonya, erdészház; Bakonya, Nagy-Rege; Cserkút, Cserkúti-dombok; Cserkút, DK; Cserkút, Szentmiklós; Kővágószőlős, Kajdács-dűlő; Kővágószőlős, Petőc-akna; Kővágótöttös, Cserma-h.; Mánfa, Nagy-Mély-v.; Orfü, Cigány-h.; Pécs, Deindol; Pécs, Éger-v.; Pécs, Mecsekszentkút, Szunyola.

Tiliacea sulphurago ([Denis \& Schiffermüller], 1775) (= Cirrhia fulvago Clerck, 1759) - Abaliget, üdülők; Bakonya, erdészház; Bakonya, Nagy-Rege; Cserkút, Cserkúti-dombok; Cserkút, DK; Cserkút, Szentmiklós; Kővágószőlős, Kajdács-dűlő; Pécs, Deindol; Pécs, Éger-v.; Pécs, Mecsekszentkút, Szunyola; Pécs, Tettye.

Lithophane socia (Hufnagel, 1766) (= hepatica Clerck, 1759) - Pécs, Deindol; Pécs, Mecsekszentkút, Szunyola.

Lithophane ornitopus (Hufnagel, 1766) - Abaliget, üdülők; Bakonya, erdészház; Bükkösd, Bükkösdi-v.; Cserkút, Cserkúti-dombok; Cserkút, DK; Cserkút, Szentmiklós; Cserkút, vízmü környék; Kővágószőlős, Kajdács-dűlő; Kővágószőlős, Petőc-akna; Mánfa, Nagy-Mély-v.; Orfü, Cigány-h.; Pécs, Árpád-tető; Pécs, Deindol; Pécs, Éger-v.; Pécs, Mecsekszentkút, erdészház; Pécs, Tettye.

Xylena exsoleta (Linnaeus, 1758) - Cserkút, Cserkúti-dombok.

Xylena vetusta (Hübner, 1813) - Cserkút, DK.

Eupsilia transversa (Hufnagel, 1766) - Abaliget, Nyáras-v.; Abaliget, üdülők; Bakonya, erdészház; Bükkösd, Bükkösdi-v.; Bükkösd, Szentdomján; Cserkút, Cserkúti-dombok; Cserkút, DK; Cserkút, Szentmiklós; Cserkút, vízmű környék; Hetvehely, Bükkösdi-v.; Kővágószőlős, Kajdács-dűlő; Kővágószőlős, Petőc-akna; Kővágótöttös, Cserma-h.; Mánfa, Nagy-Mély-v.; Orfü, Cigány-h.; Pécs, Árpád-tető; Pécs, Deindol; Pécs, Éger-v.; Pécs, Mecsekszentkút, erdészház; Pécs, Mecsekszentkút, Szunyola; Pécs, Tettye.

Conistra vaccinii (Linnaeus, 1761) - Abaliget, Nyáras-v.; Abaliget, üdülők; Bakonya, erdészház; Bükkösd, Bükkösdi-v.; Bükkösd, Szentdomján; Cserkút, Cserkúti-dombok; Cserkút, DK; Cserkút, Szentmiklós; Cserkút, vízmű környék; Hetvehely, Bükkösdi-v.; Kővágószőlős, Kajdács-dűlő; Kővágószőlős, Petőc-akna; Kővágótöttös, Bicsérdi-vízf.; Kővágótöttös, Cserma-h.; Mánfa, Nagy-Mély-v.; Orfü, Cigány-h.; Pécs, Árpádtető; Pécs, Deindol; Pécs, Éger-v.; Pécs, Mecsekszentkút, erdészház; Pécs, Mecsekszentkút, Szunyola; Pécs, Tettye.

Conistra ligula (Esper, 1791) - Cserkút, Szentmiklós; Kővágószőlős, Kajdács-dülő.

Conistra rubiginosa (Scopoli, 1763) (= vau-punctatum) - Abaliget, üdülök; Bükkösd, Bükkösdi-v.; Bükkösd, Szentdomján; Cserkút, Cserkúti-dombok; Cserkút, DK; Cserkút, Szentmiklós; Cserkút, vízmü környék; Mánfa, Nagy-Mély-v.; Pécs, Deindol; Pécs, Mecsekszentkút, erdészház; Pécs, Mecsekszentkút, Szunyola; Pécs, Tettye.

Conistra veronicae (Hübner, 1813) - Cserkút, Cserkúti-dombok; Cserkút, DK; Pécs, Deindol; Pécs, Mecsekszentkút, erdészház; Pécs, Tettye.

Conistra rubiginea ([Denis \& Schiffermüller], 1775) - Abaliget, üdülők; Bakonya, erdészház; Bakonya, Nagy-Rege; Bükkösd, Szentdomján; Cserkút, Cserkúti-dombok; Cserkút, DK; Kővágószőlős, Kajdács-dűlő; Kővágószőlős, Petőc-akna; Kővágótöttös, Cserma-h.; Mánfa, Nagy-Mély-v.; Orfü, Cigány-h.; Pécs, Deindol; Pécs, Mecsekszentkút, Szunyola; Pécs, Tettye.

Conistra erythrocephala ([Denis \& Schiffermüller], 1775) - Abaliget, üdülők; Bakonya, erdészház; Cserkút, Cserkúti-dombok; Cserkút, DK; Cserkút, Szentmiklós; Cserkút, vízmü környék; Kővágószőlős, Petőc-akna; 
Kővágótöttös, Cserma-h.; Mánfa, Nagy-Mély-v.; Orfü, Cigány-h.; Pécs, Deindol; Pécs, Mecsekszentkút, Szunyola; Pécs, Tettye.

Jodia croceago ([Denis \& Schiffermüller], 1775) - Cserkút, DK; Pécs, Árpád-tető; Pécs, Deindol; Pécs, Mecsekszentkút, Szunyola.

Agrochola lychnidis ([Denis \& Schiffermüller], 1775) - Bakonya, erdészház; Cserkút, DK; Cserkút, Szentmiklós; Kővágószőlős, Kajdács-dűlő; Pécs, Deindol; Pécs, Tettye.

Agrochola nitida ([Denis \& Schiffermüller], 1775) - Abaliget, üdülők; Bakonya, erdészház; Bakonya, Nagy-Rege; Cserkút, Cserkúti-dombok; Cserkút, DK; Cserkút, Szentmiklós; Kővágószőlős, Kajdács-dűlő; Orfü, Cigány-h.; Pécs, Deindol; Pécs, Mecsekszentkút, Szunyola; Pécs, Tettye.

Agrochola humilis ([Denis \& Schiffermüller], 1775) - Bakonya, erdészház; Cserkút, DK; Cserkút, Szentmiklós; Kővágószőlős, Kajdács-dűlő; Pécs, Deindol.

Agrochola litura (Linnaeus, 1758) - Abaliget, üdülők; Bakonya, erdészház; Bakonya, Nagy-Rege; Cserkút, Cserkúti-dombok; Cserkút, DK; Cserkút, Szentmiklós; Kővágószőlős, Kajdács-dűlő; Kővágószőlős, Petőcakna; Orfü, Cigány-h.; Pécs, Deindol; Pécs, Éger-v.; Pécs, Tettye.

Agrochola helvola (Linnaeus, 1758) - Bakonya, erdészház; Cserkút, DK; Cserkút, Szentmiklós; Kővágószőlős,

Kajdács-dűlő; Kővágószőlős, Petőc-akna; Kővágótöttös, Cserma-h.; Orfü, Cigány-h.; Pécs, Deindol; Pécs, Mecsekszentkút, Szunyola; Pécs, Tettye.

Agrochola lota (Clerck, 1759) - Cserkút, DK; Pécs, Deindol.

Agrochola macilenta (Hübner, 1809) - Bakonya, erdészház; Cserkút, DK; Cserkút, Szentmiklós; Cserkút, vízmű környék; Kővágószőlős, Kajdács-dűlő; Kővágószőlős, Petőc-akna; Kővágótöttös, Cserma-h.; Mánfa, Nagy-Mély-v.; Orfü, Cigány-h.; Pécs, Deindol; Pécs, Tettye.

Agrochola circellaris (Hufnagel, 1766) - Abaliget, üdülők; Bakonya, erdészház; Cserkút, Cserkúti-dombok;

Cserkút, vízmü környék; Kővágószőlős, Kajdács-dülő; Kővágószőlős, Petőc-akna; Kővágótöttös, Cserma-h.;

Mánfa, Nagy-Mély-v.; Orfü, Cigány-h.; Pécs, Deindol; Pécs, Mecsekszentkút, Szunyola; Pécs, Tettye.

Agrochola laevis (Hübner, 1803) - Bakonya, erdészház; Cserkút, Cserkúti-dombok; Cserkút, DK; Cserkút,

Szentmiklós; Kővágószőlős, Kajdács-dűlő; Kővágótöttös, Cserma-h.; Pécs, Deindol; Pécs, Mecsekszentkút, Szunyola; Pécs, Tettye.

Cirrhia icteritia (Hufnagel, 1766) (=Xanthia i.) - Bakonya, erdészház; Cserkút, Cserkúti-dombok; Pécs, Deindol.

Cirrhia gilvago ([Denis \& Schiffermüller], 1775) (= Xanthia g.) - Kővágószőlős, Petőc-akna.

Parastichtis suspecta (Hübner, 1817) - Cserkút, DK.

Apterogenum ypsillon ([Denis \& Schiffermüller], 1775) (= Parastichtis y., Sidemia y., S. fissipuncta) -

Abaliget, üdülők; Cserkút, DK; Mánfa, Nagy-Mély-v.; Pécs, Deindol.

Atypha pulmonaris (Esper, 1790) - Bakonya, erdészház; Bükkösd, Bükkösdi-v.; Cserkút, Cserkúti-dombok;

Cserkút, DK; Cserkút, Szentmiklós; Hetvehely, Bükkösdi-v.; Mánfa, Nagy-Mély-v.; Orfü, Cigány-h.; Pécs,

Deindol; Pécs, Mecsekszentkút, Szunyola; Pécs, Tettye; Pécs, Tubes.

Brachylomia viminalis (Fabricius, 1776) - Pécs, Deindol.

Dichonia convergens ([Denis \& Schiffermüller], 1775) - Bakonya, erdészház; Cserkút, Cserkúti-dombok;

Cserkút, DK; Cserkút, Szentmiklós; Kővágószőlős, Petőc-akna; Mánfa, Nagy-Mély-v.; Orfü, Cigány-h.; Pécs,

Deindol; Pécs, Mecsekszentkút, Szunyola.

Griposia aprilina (Linnaeus, 1758) - Pécs, Deindol.

Dryobotodes eremita (Fabricius, 1775) (= protea ([Denis \& Schiffermüller], 1775)) - Bakonya, erdészház; Cserkút, Cserkúti-dombok; Cserkút, DK; Cserkút, Szentmiklós; Mánfa, Nagy-Mély-v.; Pécs, Deindol; Pécs, Tettye.

Dryobotodes monochroma (Esper, 1790) - Kővágószőlős, Kajdács-dülő; Pécs, Deindol.

Ammoconia caecimacula ([Denis \& Schiffermüller], 1775) - Bakonya, erdészház; Cserkút, DK; Cserkút, Szentmiklós; Kővágószőlős, Kajdács-dűlő; Pécs, Deindol; Pécs, Éger-v.; Pécs, Mecsekszentkút, Szunyola; Pécs, Tettye.

Aporophyla lutulenta ([Denis \& Schiffermüller], 1775) - Bakonya, erdészház; Kővágószőlős, Kajdács-dűlő;

Pécs, Deindol. 
Polymixis polymita (Linnaeus, 1761) - Pécs, Deindol.

Blepharita satura ([Denis \& Schiffermüller], 1775) (= Mniotype s.) - Abaliget, üdülök; Bakonya, erdészház; Cserkút, Cserkúti-dombok; Cserkút, DK; Cserkút, Szentmiklós; Kővágószőlős, Kajdács-dủlő; Pécs, Deindol; Pécs, Éger-v.; Pécs, Tettye.

Mesogona acetosellae ([Denis \& Schiffermüller], 1775) - Bakonya, erdészház; Cserkút, DK; Cserkút, Szentmiklós; Pécs, Deindol; Pécs, Mecsekszentkút, Szunyola; Pécs, Tettye.

\section{Hadeninae}

Mythimna turca (Linnaeus, 1761) - Abaliget, Nyáras-v.; Abaliget, üdülők; Bakonya, erdészház; Bakonya, Nagy-Rege; Bükkösd, Bükkösdi-v.; Cserkút, Cserkúti-dombok; Cserkút, DK; Kövágótöttös, Cserma-h.; Orfü, Cigány-h.; Pécs, Deindol.

Mythimna pudorina ([Denis \& Schiffermüller], 1775) - Abaliget, Nyáras-v.; Cserkút, Cserkúti-dombok; Cserkút, Szentmiklós; Kővágószőlős, Kajdács-dűlő; Kővágószőlős, Petőc-akna; Orfü, Cigány-h.

Mythimna conigera ([Denis \& Schiffermüller], 1775) - Pécs, Deindol.

Mythimna pallens (Linnaeus, 1758) - Bakonya, erdészház; Bakonya, Nagy-Rege; Bükkösd, Bükkösdi-v.; Cserkút, DK; Cserkút, Szentmiklós; Hetvehely, Bükkösdi-v.; Kővágószőlős, Kajdács-dülő; Orfü, Cigány-h.; Pécs, Mecsekszentkút, erdészház; Pécs, Mecsekszentkút, Szunyola; Pécs, Tettye.

Mythimna impura (Hübner, 1808) - Cserkút, DK; Cserkút, Szentmiklós.

Mythimna straminea (Treitschke, 1825) - Abaliget, üdülők; Cserkút, Cserkúti-dombok.

Mythimna vitellina (Hübner, 1808) - Abaliget, üdülök; Bükkösd, Bükkösdi-v.; Bükkösd, Szentdomján; Hetvehely, Bükkösdi-v.; Kővágószőlős, Kajdács-dűlő; Mánfa, Nagy-Mély-v.; Pécs, Deindol; Pécs, Mecsekszentkút, Szunyola.

Mythimna albipuncta ([Denis \& Schiffermüller], 1775) - Abaliget, Nyáras-v.; Abaliget, üdülök; Bakonya, erdészház; Bakonya, Nagy-Rege; Bükkösd, Bükkösdi-v.; Bükkösd, Szentdomján; Cserkút, Cserkúti-dombok; Cserkút, DK; Cserkút, Szentmiklós; Kővágószőlős, Kajdács-dűlő; Kővágószőlős, Petőc-akna; Kővágótöttös, Cserma-h.; Mánfa, Nagy-Mély-v.; Orfü, Cigány-h.; Pécs, Deindol; Pécs, Mecsekszentkút, Szunyola; Pécs, Tettye.

Mythimna ferrago (Fabricius, 1787) - Abaliget, Nyáras-v.; Abaliget, üdülők; Bakonya, Nagy-Rege; Cserkút, Cserkúti-dombok; Cserkút, DK; Cserkút, Szentmiklós; Hetvehely, Bükkösdi-v.; Kővágótöttös, Cserma-h.; Mánfa, Nagy-Mély-v.; Pécs, Deindol; Pécs, Mecsekszentkút, Szunyola; Pécs, Tettye.

Mythimna l-album (Linnaeus, 1767) - Abaliget, üdülök; Bakonya, Nagy-Rege; Bükkösd, Szentdomján; Cserkút, DK; Cserkút, Szentmiklós; Kővágószőlős, Kajdács-dülő; Pécs, Deindol; Pécs, Éger-v.; Pécs, Mecsekszentkút, Szunyola; Pécs, Tettye.

Leucania comma (Linnaeus, 1761) - Bükkösd, Szentdomján.

Leucania obsoleta (Hübner, 1803) - Cserkút, DK; Pécs, Tettye.

Hadula trifolii (Hufnagel, 1766) (= Discestra t.) - Bakonya, Nagy-Rege; Cserkút, Cserkúti-dombok; Cserkút, DK; Cserkút, Szentmiklós; Hetvehely, Bükkösdi-v.; Kővágószőlős, Kajdács-dủlő; Pécs, Deindol; Pécs, Mecsekszentkút, Szunyola; Pécs, Tettye.

Sideridis rivularis (Fabricius, 1775) (= Hadena r., H. cucubali) - Abaliget, üdülök; Bakonya, Nagy-Rege; Bükkösd, Bükkösdi-v.; Cserkút, DK; Kővágószőlős, Kajdács-dűlő; Mánfa, Nagy-Mély-v.; Pécs, Deindol.

Conisania luteago ([Denis \& Schiffermüller], 1775) (= Hadena l.) - Bakonya, Nagy-Rege; Cserkút, Cserkúti-dombok; Cserkút, DK; Kővágószőlős, Kajdács-dűlő; Pécs, Deindol; Pécs, Tettye.

Polia nebulosa (Hufnagel, 1766) - Bakonya, erdészház.

Mamestra brassicae (Linnaeus, 1758) - Abaliget, üdülők; Cserkút, Cserkúti-dombok; Cserkút, Szentmiklós; Hetvehely, Bükkösdi-v.; Kövágószőlős, Kajdács-dűlő; Kővágószőlős, Petőc-akna; Mánfa, Nagy-Mély-v.; Pécs, Deindol; Pécs, Mecsekszentkút, erdészház; Pécs, Mecsekszentkút, Szunyola; Pécs, Tettye.

Melanchra persicariae (Linnaeus, 1761) (= Mamestra p.) - Abaliget, üdülők; Bakonya, Sás-v.; Cserkút, DK; Mánfa, Nagy-Mély-v.; Pécs, Deindol; Pécs, Mecsekszentkút, Szunyola; Pécs, Tettye.

Ceramica pisi (Linnaeus, 1758) (= Mamestra p.) - Pécs, Deindol.

Lacanobia w-latinum (Hufnagel, 1766) - Abaliget, üdülők; Bakonya, erdészház; Bakonya, Nagy-Rege; Bükkösd, Szentdomján; Cserkút, Cserkúti-dombok; Cserkút, DK; Cserkút, Szentmiklós; Hetvehely, 
Bükkösdi-v.; Kővágószőlős, Kajdács-dűlő; Pécs, Deindol; Pécs, Mecsekszentkút, erdészház; Pécs, Tettye; Pécs, Tubes.

Lacanobia thalassina (Hufnagel, 1766) - Abaliget, üdülők; Bakonya, erdészház; Cserkút, Cserkúti-dombok;

Cserkút, DK; Cserkút, Szentmiklós; Pécs, Deindol; Pécs, Mecsekszentkút, erdészház.

Lacanobia contigua ([Denis \& Schiffermüller], 1775) - Bakonya, erdészház; Bakonya, Nagy-Rege;

Cserkút, DK; Cserkút, Szentmiklós.

Lacanobia suasa ([Denis \& Schiffermüller], 1775) - Abaliget, üdülök; Bükkösd, Bükkösdi-v.; Cserkút,

Cserkúti-dombok; Cserkút, DK; Cserkút, Szentmiklós; Hetvehely, Bükkösdi-v.; Pécs, Deindol; Pécs, Tettye.

Lacanobia oleracea (Linnaeus, 1758) - Abaliget, Nyáras-v.; Abaliget, üdülők; Bakonya, erdészház;

Bakonya, Nagy-Rege; Bükkösd, Bükkösdi-v.; Cserkút, Cserkúti-dombok; Cserkút, DK; Cserkút, Szentmiklós;

Hetvehely, Bükkösdi-v.; Kővágószőlős, Kajdács-dűlő; Kővágószőlős, Petőc-akna; Pécs, Deindol; Pécs, Mecsekszentkút, erdészház; Pécs, Tettye.

Hecatera bicolorata (Hufnagel, 1766) (= serena ([Denis \& Schiffermüller], 1775)) - Cserkút, DK; Kővágószőlős, Kajdács-dülö; Pécs, Deindol.

Hecatera dysodea ([Denis \& Schiffermüller], 1775) (= Aetheria d.) - Cserkút, Cserkúti-dombok; Cserkút, DK; Cserkút, Szentmiklós; Pécs, Deindol.

Hadena bicruris (Hufnagel, 1766) - Abaliget, üdülők; Cserkút, Cserkúti-dombok; Cserkút, Szentmiklós; Hetvehely, Bükkösdi-v.; Pécs, Deindol; Pécs, Tettye.

Hadena confusa (Hufnagel, 1766) - Cserkút, Cserkúti-dombok; Cserkút, DK; Cserkút, Szentmiklós.

Hadena filograna (Esper, 1788) (= filigrama (Espere, 1796)) - Kővágószőlős, Kajdács-dűlő.

Hadena perplexa ([Denis \& Schiffermüller], 1775) (= lepida) - Cserkút, DK; Cserkút, Szentmiklós; Hetvehely, Bükkösdi-v.; Pécs, Deindol; Pécs, Tettye.

Panolis flammea ([Denis \& Schiffermüller], 1775) - Abaliget, üdülők; Bakonya, erdészház; Hetvehely, Bükkösdi-v.; Orfü, Cigány-h.; Pécs, Árpád-tető; Pécs, Deindol; Pécs, Mecsekszentkút, Szunyola; Pécs, Tettye.

Orthosia incerta (Hufnagel, 1766) - Abaliget, Nyáras-v.; Abaliget, üdülök; Bakonya, erdészház; Bükkösd, Bükkösdi-v.; Bükkösd, Szentdomján; Cserkút, Cserkúti-dombok; Cserkút, DK; Cserkút, Szentmiklós; Cserkút, vízmű környék; Hetvehely, Bükkösdi-v.; Kővágószőlős, Kajdács-dűlő; Kővágószőlős, Petőc-akna; Kővágótöttös, Bicsérdi-vízf.; Mánfa, Nagy-Mély-v.; Orfü, Cigány-h.; Pécs, Árpád-tető; Pécs, Deindol; Pécs, Éger-v.; Pécs, Mecsekszentkút, erdészház; Pécs, Mecsekszentkút, Szunyola; Pécs, Tettye.

Orthosia miniosa ([Denis \& Schiffermüller], 1775) - Abaliget, Nyáras-v.; Cserkút, Cserkúti-dombok; Cserkút, DK; Hetvehely, Bükkösdi-v.; Kővágószőlős, Kajdács-dűlő; Pécs, Deindol; Pécs, Mecsekszentkút, erdészház; Pécs, Mecsekszentkút, Szunyola; Pécs, Tettye.

Orthosia cerasi (Fabricius, 1775) (= stabilis ([Denis \& Schiffermüller], 1775)) - Abaliget, Nyáras-v.; Abaliget, üdülök; Bakonya, erdészház; Bükkösd, Bükkösdi-v.; Bükkösd, Szentdomján; Cserkút, Cserkúti-dombok; Cserkút, DK; Cserkút, vízmü környék; Kővágószőlős, Kajdács-dűlő; Kővágószőlős, Petőc-akna; Kővágótöttös, Bicsérdi-vízf.; Mánfa, Nagy-Mély-v.; Orfü, Cigány-h.; Pécs, Árpád-tető; Pécs, Deindol; Pécs, Éger-v.; Pécs, Mecsekszentkút, erdészház; Pécs, Mecsekszentkút, Szunyola; Pécs, Tettye.

Orthosia cruda ([Denis \& Schiffermüller], 1775) - Abaliget, Nyáras-v.; Bakonya, erdészház; Bükkösd, Bükkösdi-v.; Bükkösd, Szentdomján; Cserkút, Cserkúti-dombok; Cserkút, DK; Cserkút, vízmű környék; Kővágószőlős, Kajdács-dűlő; Kővágótöttös, Bicsérdi-vízf.; Mánfa, Nagy-Mély-v.; Orfü, Cigány-h.; Pécs, Árpádtető; Pécs, Deindol; Pécs, Éger-v.; Pécs, Mecsekszentkút, erdészház; Pécs, Mecsekszentkút, Szunyola; Pécs, Tettye.

Orthosia gracilis ([Denis \& Schiffermüller], 1775) - Bakonya, erdészház; Pécs, Árpád-tető.

Orthosia opima (Hübner, 1809) - Kővágószőlős, Kajdács-dülő.

Orthosia gothica (Linnaeus, 1758) - Abaliget, Nyáras-v.; Abaliget, üdülök; Bakonya, erdészház; Bükkösd, Bükkösdi-v.; Bükkösd, Szentdomján; Cserkút, Cserkúti-dombok; Cserkút, DK; Cserkút, Szentmiklós; Cserkút, vízmű környék; Hetvehely, Bükkösdi-v.; Kővágószőlős, Kajdács-dűlő; Kővágótöttös, Bicsérdi-vízf.; Mánfa, Nagy-Mély-v.; Orfü, Cigány-h.; Pécs, Árpád-tető; Pécs, Deindol; Pécs, Mecsekszentkút, erdészház; Pécs, Mecsekszentkút, Szunyola; Pécs, Tettye. 
Anorthoa munda ([Denis \& Schiffermüller], 1775) (=Orthosia m.) - Bakonya, erdészház; Bükkösd, Bükkösdi-v.; Bükkösd, Szentdomján; Cserkút, Cserkúti-dombok; Cserkút, DK; Cserkút, vízmü környék; Kővágószőlős, Kajdács-dűlő; Kővágótöttös, Bicsérdi-vízf.; Mánfa, Nagy-Mély-v.; Orfü, Cigány-h.; Pécs, Árpádtető; Pécs, Deindol; Pécs, Éger-v.; Pécs, Mecsekszentkút, erdészház; Pécs, Mecsekszentkút, Szunyola; Pécs, Tettye.

Perigrapha i-cinctum ([Denis \& Schiffermüller], 1775) - Pécs, Deindol.

Egira conspicillaris (Linnaeus, 1758) (=Xylomiges c.) - Abaliget, üdülők; Bakonya, erdészház; Cserkút, Cserkútidombok; Cserkút, DK; Cserkút, Szentmiklós; Hetvehely, Bükkösdi-v.; Kővágószőlős, Kajdács-dűlő; Kővágószőlős, Petőc-akna; Pécs, Árpád-tető; Pécs, Deindol; Pécs, Mecsekszentkút, erdészház; Pécs, Mecsekszentkút, Szunyola; Pécs, Tettye.

Tholera cespitis ([Denis \& Schiffermüller], 1775) - Abaliget, üdülök; Cserkút, DK.

Tholera decimalis (Poda, 1761) - Abaliget, üdülők; Cserkút, DK; Cserkút, Szentmiklós; Kővágószőlős, Kajdács-dülő; Mánfa, Nagy-Mély-v.

\section{Noctuinae}

Peridroma saucia (Hübner, 1808) - Cserkút, Cserkúti-dombok; Mánfa, Nagy-Mély-v.; Pécs, Deindol. Dichagyris signifera ([Denis \& Schiffermüller], 1775) (= Yigoga s.) -Cserkút, Szentmiklós.

Euxoa obelisca ([Denis \& Schiffermüller], 1775) - Abaliget, üdülők; Cserkút, DK; Cserkút, Szentmiklós; Pécs, Deindol; Pécs, Tettye.

Euxoa temera (Hübner, 1808) - Cserkút, DK; Cserkút, Szentmiklós; Pécs, Deindol; Pécs, Tettye.

Euxoa aquilina ([Denis \& Schiffermüller], 1775) - Cserkút, DK; Cserkút, Szentmiklós.

Euxoa tritici (Linnaeus, 1761) (= crypta (Dadd, 1927)) - Pécs, Deindol.

Agrotis cinerea ([Denis \& Schiffermüller], 1775) - Cserkút, Cserkúti-dombok; Cserkút, DK; Cserkút, Szentmiklós; Pécs, Deindol; Pécs, Tettye.

Agrotis exclamationis (Linnaeus, 1758) - Abaliget, Nyáras-v.; Abaliget, üdülők; Bakonya, erdészház; Bakonya, Nagy-Rege; Bükkösd, Bükkösdi-v.; Bükkösd, Szentdomján; Cserkút, Cserkúti-dombok; Cserkút, DK; Cserkút, Szentmiklós; Kővágószőlős, Kajdács-dűlő; Kővágószőlős, Petőc-akna; Kővágótöttös, Cserma-h.; Mánfa, Nagy-Mély-v.; Orfü, Cigány-h.; Pécs, Deindol; Pécs, Mecsekszentkút, erdészház; Pécs, Mecsekszentkút, Szunyola; Pécs, Tettye.

Agrotis segetum ([Denis \& Schiffermüller], 1775) - Abaliget, üdülők; Bakonya, erdészház; Bakonya, NagyRege; Bakonya, Sás-v.; Bükkösd, Szentdomján; Cserkút, Cserkúti-dombok; Cserkút, DK; Cserkút, Szentmiklós; Kővágószőlős, Kajdács-dűlő; Kővágószőlős, Petőc-akna; Kővágótöttös, Cserma-h.; Mánfa, Nagy-Mély-v.; Pécs, Deindol; Pécs, Mecsekszentkút, erdészház; Pécs, Mecsekszentkút, Szunyola; Pécs, Tettye.

Agrotis clavis (Hufnagel, 1766) - Cserkút, DK; Cserkút, Szentmiklós.

Agrotis ipsilon (Hufnagel, 1766) - Abaliget, üdülök; Bakonya, erdészház; Bükkösd, Bükkösdi-v.; Cserkút, DK; Cserkút, Szentmiklós; Kővágószőlős, Kajdács-dűlő; Mánfa, Nagy-Mély-v.; Pécs, Deindol; Pécs, Tettye; Pécs, Tubes.

Axylia putris (Linnaeus, 1761) - Abaliget, Nyáras-v.; Abaliget, üdülök; Bakonya, erdészház; Bakonya, Nagy-Rege; Bakonya, Sás-v.; Bükkösd, Bükkösdi-v.; Bükkösd, Szentdomján; Cserkút, Cserkúti-dombok; Cserkút, DK; Cserkút, Szentmiklós; Kővágószőlős, Kajdács-dűlő; Kővágószőlős, Petőc-akna; Mánfa, NagyMély-v.; Orfü, Cigány-h.; Pécs, Deindol; Pécs, Tettye; Pécs, Tubes.

Ochropleura plecta (Linnaeus, 1761) - Abaliget, Nyáras-v.; Abaliget, üdülők; Bakonya, erdészház; Bakonya, Nagy-Rege; Bakonya, Sás-v.; Bükkösd, Bükkösdi-v.; Bükkösd, Szentdomján; Cserkút, Cserkútidombok; Cserkút, DK; Cserkút, Szentmiklós; Kővágószőlős, Petőc-akna; Kővágótöttös, Cserma-h.; Mánfa, Nagy-Mély-v.; Orfü, Cigány-h.; Pécs, Deindol; Pécs, Mecsekszentkút, erdészház; Pécs, Mecsekszentkút, Szunyola; Pécs, Tettye; Pécs, Tubes.

Diarsia brunnea ([Denis \& Schiffermüller], 1775) - Mánfa, Nagy-Mély-v.

Diarsia rubi (Vieweg, 1790) - Abaliget, üdülők; Mánfa, Nagy-Mély-v.; Pécs, Tubes.

Cerastis rubricosa ([Denis \& Schiffermüller], 1775) - Abaliget, Nyáras-v.; Bakonya, erdészház; Bükkösd, Bükkösdi-v.; Bükkösd, Szentdomján; Cserkút, Cserkúti-dombok; Cserkút, DK; Cserkút, Szentmiklós; 
Hetvehely, Bükkösdi-v.; Kővágószőlős, Kajdács-dűlő; Kővágószőlős, Petőc-akna; Kővágótöttös, Bicsérdivízf.; Mánfa, Nagy-Mély-v.; Orfü, Cigány-h.; Pécs, Árpád-tető; Pécs, Deindol; Pécs, Éger-v.; Pécs, Mecsekszentkút, erdészház; Pécs, Mecsekszentkút, Szunyola; Pécs, Tettye.

Cerastis leucographa ([Denis \& Schiffermüller], 1775) - Abaliget, Nyáras-v.; Bükkösd, Szentdomján; Kővágószőlős, Kajdács-dűlő; Kővágószőlős, Petőc-akna; Orfü, Cigány-h.; Pécs, Árpád-tető; Pécs, Deindol; Pécs, Éger-v.; Pécs, Mecsekszentkút, erdészház; Pécs, Mecsekszentkút, Szunyola; Pécs, Tettye.

Chersotis rectangula ([Denis \& Schiffermüller], 1775) - Cserkút, Szentmiklós; Pécs, Deindol.

Chersotis multangula (Hübner, 1803) - Mánfa, Nagy-Mély-v.; Pécs, Deindol; Pécs, Tettye.

Noctua pronuba Linnaeus, 1758 - Abaliget, üdülők; Bakonya, erdészház; Bakonya, Nagy-Rege; Bükkösd, Bükkösdi-v.; Bükkösd, Szentdomján; Cserkút, Cserkúti-dombok; Cserkút, DK; Cserkút, Szentmiklós; Hetvehely, Bükkösdi-v.; Kővágószőlős, Kajdács-dűlő; Kővágószőlős, Petőc-akna; Kővágótöttös, Cserma-h.; Mánfa, Nagy-Mély-v.; Orfü, Cigány-h.; Pécs, Deindol; Pécs, Mecsekszentkút, Szunyola; Pécs, Tettye.

Noctua fimbriata (Schreber, 1759) - Abaliget, üdülők; Bakonya, Nagy-Rege; Bakonya, Sás-v.; Bükkösd, Bükkösdi-v.; Bükkösd, Szentdomján; Cserkút, Cserkúti-dombok; Cserkút, DK; Cserkút, Szentmiklós; Kővágószőlős, Kajdács-dűlő; Orfü, Cigány-h.; Pécs, Deindol; Pécs, Mecsekszentkút, Szunyola; Pécs, Tettye. Noctua orbona (Hufnagel, 1766) - Abaliget, üdülők; Bakonya, Nagy-Rege; Bükkösd, Bükkösdi-v.; Cserkút, DK; Cserkút, Szentmiklós; Pécs, Deindol; Pécs, Mecsekszentkút, Szunyola; Pécs, Tettye.

Noctua interposita (Hübner, 1790) - Bakonya, Nagy-Rege; Bakonya, Sás-v.; Cserkút, DK; Kővágószőlős, Kajdács-dűlő; Pécs, Deindol; Pécs, Mecsekszentkút, Szunyola.

Noctua comes Hübner, 1813 - Bakonya, Nagy-Rege; Cserkút, Cserkúti-dombok; Kővágószőlős, Kajdácsdülö; Pécs, Deindol; Pécs, Mecsekszentkút, Szunyola.

Noctua interjecta Hübner, 1803 - Bakonya, Nagy-Rege; Kővágószőlős, Kajdács-dűlő; Pécs, Deindol; Pécs, Mecsekszentkút, Szunyola.

Noctua janthina ([Denis \& Schiffermüller], 1775) - Abaliget, üdülök; Bükkösd, Szentdomján; Cserkút, Cserkúti-dombok; Cserkút, DK; Cserkút, Szentmiklós; Kővágószőlős, Kajdács-dűlő; Kővágószőlős, Petőcakna; Mánfa, Nagy-Mély-v.; Orfü, Cigány-h.; Pécs, Deindol; Pécs, Mecsekszentkút, Szunyola.

Noctua janthe (Borkhausen, 1792) - Kővágószőlős, Kajdács-dűlő; Pécs, Deindol.

Epilecta linogrisea ([Denis \& Schiffermüller], 1775) - Abaliget, üdülök; Cserkút, Cserkúti-dombok; Cserkút, DK; Cserkút, Szentmiklós; Kővágószőlős, Kajdács-dülő; Pécs, Deindol.

Opigena polygona ([Denis \& Schiffermüller], 1775) - Pécs, Deindol.

Xestia baja ([Denis \& Schiffermüller], 1775) - Abaliget, üdülők; Hetvehely, Bükkösdi-v.; Pécs, Deindol; Pécs, Mecsekszentkút, Szunyola.

Xestia stigmatica (Hübner, 1813) (= rhomboidea (Esper, 1790)) - Abaliget, Nyáras-v.; Bakonya, Nagy-

Rege; Cserkút, DK; Orfü, Cigány-h.; Pécs, Deindol.

Xestia castanea (Esper, 1798) - Bakonya, erdészház; Kővágószőlős, Kajdács-dűlő; Orfü, Cigány-h.; Pécs, Deindol.

Xestia xanthographa ([Denis \& Schiffermüller], 1775) - Abaliget, üdülők; Bakonya, erdészház; Bakonya, Nagy-Rege; Bükkösd, Szentdomján; Cserkút, DK; Cserkút, Szentmiklós; Kővágószőlős, Kajdács-dủlő; Pécs, Deindol; Pécs, Éger-v.; Pécs, Tettye.

Xestia c-nigrum (Linnaeus, 1758) - Abaliget, Nyáras-v.; Abaliget, üdülök; Bakonya, erdészház; Bakonya, Nagy-Rege; Bükkösd, Bükkösdi-v.; Bükkösd, Szentdomján; Cserkút, Cserkúti-dombok; Cserkút, DK; Cserkút, Szentmiklós; Hetvehely, Bükkösdi-v.; Kővágószőlős, Kajdács-dűlő; Kővágószőlős, Petőc-akna; Mánfa, NagyMély-v.; Orfü, Cigány-h.; Pécs, Deindol; Pécs, Mecsekszentkút, erdészház; Pécs, Mecsekszentkút, Szunyola; Pécs, Tettye.

Xestia triangulum (Hufnagel, 1766) - Abaliget, üdülők; Cserkút, Cserkúti-dombok; Cserkút, DK; Cserkút, Szentmiklós; Mánfa, Nagy-Mély-v.; Pécs, Deindol; Pécs, Mecsekszentkút, Szunyola; Pécs, Tettye.

Eugnorisma depuncta (Linnaeus, 1761) - Abaliget, üdülők; Bükkösd, Bükkösdi-v.; Cserkút, DK; Cserkút, Szentmiklós; Kővágószőlős, Kajdács-dűlő; Mánfa, Nagy-Mély-v.; Pécs, Deindol; Pécs, Mecsekszentkút, Szunyola; Pécs, Tettye.

Naenia typica (Linnaeus, 1758) - Hetvehely, Bükkösdi-v. 


\section{Hesperiidae}

Erynnis tages (Linnaeus, 1758) - Abaliget, Nyáras-v.; Bakonya, Nagy-Rege; Bükkösd, Bükkösdi-v.; Bükkösd, Szentdomján; Cserkút, Cserkúti-dombok; Hetvehely, Bükkösdi-v.; Mánfa, Nagy-Mély-v.; Orfü, Cigány-h.; Pécs, Árpád-tető; Pécs, Deindol; Pécs, Éger-v.; Pécs, Mecsekszentkút, erdészház; Pécs, Mecsekszentkút, Szunyola; Pécs, Remete-rét; Pécs, Tubes.

Carcharodus alceae (Esper, 1780) - Bükkösd, Szentdomján; Cserkút, Cserkúti-dombok; Cserkút, DK; Pécs, Deindol; Pécs, Mecsekszentkút, Szunyola; Pécs, Tubes.

Spialia orbifer (Hübner, 1823) - Cserkút, Cserkúti-dombok; Cserkút, DK; Pécs, Deindol; Pécs, Tubes.

Pyrgus malvae (Linnaeus, 1758) - Abaliget, Nyáras-v.; Abaliget, üdülők; Bakonya, Nagy-Rege; Bakonya, Sás-v.; Bükkösd, Bükkösdi-v.; Bükkösd, Szentdomján; Cserkút, Cserkúti-dombok; Cserkút, DK; Hetvehely, Bükkösdi-v.; Kővágószőlős, Kajdács-dűlő; Pécs, Árpád-tető; Pécs, Deindol; Pécs, Éger-v.; Pécs, Mandulás; Pécs, Mecsekszentkút, erdészház; Pécs, Tubes.

Pyrgus armoricanus (Oberthür, 1910) - Pécs, Árpád-tető.

Pyrgus carthami (Hübner, 1813) (= fritillarius) - Pécs, Tubes.

Pyrgus alveus (Hübner, 1803) - Pécs, Árpád-tető.

Carterocephalus palaemon (Pallas, 1771) - Abaliget, Nyáras-v.; Bakonya, Sás-v.; Bükkösd, Bükkösdi-v.; Mánfa, Nagy-Mély-v.; Pécs, Deindol.

Heteropterus morpheus (Pallas, 1771) - Bükkösd, Bükkösdi-v.; Hetvehely, Bükkösdi-v.; Pécs, Árpád-tető; Pécs, Deindol; Pécs, Éger-v.; Pécs, Mecsekszentkút, Szunyola.

Hesperia comma (Linnaeus, 1758) - Bakonya, Nagy-Rege; Cserkút, DK; Kővágószőlős, Kajdács-dűlő; Mánfa, Nagy-Mély-v.; Pécs, Mecsekszentkút, Szunyola; Pécs, Remete-rét; Pécs, Tubes.

Ochlodes sylvanus (Esper, 1779) (= O. venata (Bremer \& Grey, 1853)) - Abaliget, Nyáras-v.; Abaliget, üdülők; Bakonya, Nagy-Rege; Bakonya, Sás-v.; Bükkösd, Szentdomján; Cserkút, Cserkúti-dombok; Cserkút, DK; Hetvehely, Bükkösdi-v.; Kővágótöttös, Cserma-h.; Mánfa, Nagy-Mély-v.; Orfü, Cigány-h.; Pécs, Árpád-tető; Pécs, Deindol; Pécs, Éger-v.; Pécs, Mecsekszentkút, Szunyola; Pécs, Remete-rét; Pécs, Tubes.

Thymelicus lineola (Ochsenheimer, 1808) - Abaliget, üdülők; Cserkút, Cserkúti-dombok; Kővágószőlős, Kajdács-dűlő; Pécs, Árpád-tető; Pécs, Éger-v.; Pécs, Remete-rét; Pécs, Tubes.

Thymelicus sylvestris (Poda, 1761) - Bakonya, Nagy-Rege; Bükkösd, Bükkösdi-v.; Cserkút, Cserkútidombok; Cserkút, DK; Pécs, Árpád-tető; Pécs, Deindol; Pécs, Éger-v.; Pécs, Tubes.

\section{Papilionidae}

Zerynthia polyxena ([Denis \& Schiffermüller], 1775) - Cserkút, DK; Pécs, Deindol; Pécs, Tubes. Parnassius mnemosyne (Linnaeus, 1758) - Abaliget, Nyáras-v.; Pécs, Deindol; Pécs, Tettye; Pécs, Tubes.

Iphiclides podalirius (Linnaeus, 1758) - Bakonya, Nagy-Rege; Bükkösd, Bükkösdi-v.; Bükkösd, Szentdomján; Cserkút, Cserkúti-dombok; Hetvehely, Bükkösdi-v.; Kővágószőlős, Kajdács-dülő; Pécs, Deindol; Pécs, Éger-v.; Pécs, Mecsekszentkút, erdészház; Pécs, Mecsekszentkút, Szunyola; Pécs, Tubes.

Papilio machaon Linnaeus, 1758 - Bakonya, Nagy-Rege; Bakonya, Sás-v.; Bükkösd, Bükkösdi-v.; Bükkösd, Szentdomján; Cserkút, Cserkúti-dombok; Kővágószőlős, Kajdács-dűlő; Orfü, Cigány-h.; Pécs, Deindol; Pécs, Éger-v.; Pécs, Tubes.

\section{Pieridae}

Colias hyale (Linnaeus, 1758) - Bakonya, Nagy-Rege; Bakonya, Sás-v.; Bükkösd, Bükkösdi-v.; Bükkösd, Szentdomján; Cserkút, Cserkúti-dombok; Hetvehely, Bükkösdi-v.; Kővágószőlős, Kajdács-dülő; Pécs, Árpádtető; Pécs, Éger-v.; Pécs, Mecsekszentkút, erdészház; Pécs, Mecsekszentkút, Szunyola; Pécs, Remete-rét; Pécs, Tubes.

Colias alfacariensis Ribbe, 1905 (= C. australis) - Bükkösd, Bükkösdi-v.; Bükkösd, Szentdomján; Cserkút, DK; Pécs, Deindol; Pécs, Mecsekszentkút, Szunyola; Pécs, Remete-rét; Pécs, Tubes.

Colias erate (Esper, 1805) - Cserkút, Cserkúti-dombok; Hetvehely, Bükkösdi-v.; Kővágószőlős, Kajdácsdűlő; Kővágótöttös, Bicsérdi-vízf.; Pécs, Deindol. 
Colias croceus (Fourcroy, 1785) - Bakonya, Nagy-Rege; Bükkösd, Bükkösdi-v.; Cserkút, Cserkúti-dombok; Cserkút, DK; Kővágószőlős, Kajdács-dűlő; Kővágótöttös, Bicsérdi-vízf.; Pécs, Árpád-tető; Pécs, Deindol; Pécs, Éger-v.; Pécs, Tubes.

Gonepteryx rhamni (Linnaeus, 1758) - Abaliget, Nyáras-v.; Bakonya, Nagy-Rege; Bükkösd, Bükkösdi-v.; Bükkösd, Szentdomján; Cserkút, Cserkúti-dombok; Hetvehely, Bükkösdi-v.; Kővágószőlős, Kajdács-dűlő; Kővágótöttös, Bicsérdi-vízf.; Mánfa, Nagy-Mély-v.; Orfü, Cigány-h.; Orfü, Vörös-h.; Pécs, Árpád-tető; Pécs, Deindol; Pécs, Éger-v.; Pécs, Mecsekszentkút, Szunyola; Pécs, Remete-rét; Pécs, Tubes.

Leptidea morsei major Grund, 1905 - Abaliget, Nyáras-v.; Mánfa, Nagy-Mély-v.; Pécs, Deindol; Pécs, Éger-v.; Pécs, Tubes.

Leptidea sinapis (Linnaeus, 1758) - Abaliget, Nyáras-v.; Abaliget, üdülök; Bakonya, Nagy-Rege; Bakonya, Sás-v.; Bükkösd, Bükkösdi-v.; Bükkösd, Szentdomján; Cserkút, Cserkúti-dombok; Cserkút, DK; Hetvehely, Bükkösdi-v.; Kővágószőlős, Kajdács-dűlő; Kővágótöttös, Cserma-h.; Mánfa, Nagy-Mély-v.; Orfü, Cigány-h.; Pécs, Árpád-tető; Pécs, Deindol; Pécs, Éger-v.; Pécs, Mecsekszentkút, erdészház; Pécs, Mecsekszentkút, Szunyola; Pécs, Remete-rét; Pécs, Tubes.

Aporia crataegi (Linnaeus, 1758) - Cserkút, DK; Pécs, Tubes.

Pieris brassicae (Linnaeus, 1758) - Abaliget, üdülők; Bakonya, Nagy-Rege; Bükkösd, Bükkösdi-v.; Bükkösd, Szentdomján; Cserkút, Cserkúti-dombok; Kővágószőlős, Kajdács-dűlő; Pécs, Árpád-tető; Pécs, Deindol; Pécs, Éger-v.; Pécs, Mecsekszentkút, Szunyola; Pécs, Tubes.

Pieris rapae (Linnaeus, 1758) - Bakonya, Nagy-Rege; Bükkösd, Bükkösdi-v.; Bükkösd, Szentdomján; Cserkút, Cserkúti-dombok; Cserkút, DK; Hetvehely, Bükkösdi-v.; Kővágószőlős, Kajdács-dűlő; Kővágótöttös, Bicsérdi-vízf.; Mánfa, Nagy-Mély-v.; Orfü, Cigány-h.; Pécs, Árpád-tető; Pécs, Deindol; Pécs, Éger-v.; Pécs, Mecsekszentkút, erdészház; Pécs, Mecsekszentkút, Szunyola; Pécs, Remete-rét; Pécs, Tubes.

Pieris napi (Linnaeus, 1758) - Abaliget, Nyáras-v.; Bakonya, Nagy-Rege; Bakonya, Sás-v.; Bükkösd, Bükkösdi-v.; Bükkösd, Szentdomján; Cserkút, Cserkúti-dombok; Cserkút, DK; Hetvehely, Bükkösdi-v.; Kővágószőlős, Kajdács-dűlő; Kővágótöttös, Bicsérdi-vízf.; Kővágótöttös, Cserma-h.; Mánfa, Nagy-Mély-v.; Orfü, Cigány-h.; Pécs, Árpád-tető; Pécs, Deindol; Pécs, Éger-v.; Pécs, Keresztkunyhó; Pécs, Mecsekszentkút, erdészház; Pécs, Mecsekszentkút, Szunyola; Pécs, Remete-rét; Pécs, Tubes.

Pontia daplidice edusa (Fabricius, 1777) - Bükkösd, Bükkösdi-v.; Cserkút, Cserkúti-dombok; Cserkút, DK; Kővágószőlős, Kajdács-dűlő; Pécs, Árpád-tető; Pécs, Deindol; Pécs, Éger-v.; Pécs, Remete-rét; Pécs, Tubes.

Anthocharis cardamines (Linnaeus, 1758) - Abaliget, Nyáras-v.; Bakonya, Nagy-Rege; Bakonya, Sás-v.; Bükkösd, Bükkösdi-v.; Bükkösd, Szentdomján; Cserkút, Cserkúti-dombok; Cserkút, DK; Hetvehely, Bükkösdi-v.; Kővágószőlős, Kajdács-dűlő; Mánfa, Nagy-Mély-v.; Orfü, Cigány-h.; Pécs, Árpád-tető; Pécs, Deindol; Pécs, Éger-v.; Pécs, Mandulás; Pécs, Mecsekszentkút, erdészház; Pécs, Mecsekszentkút, Szunyola; Pécs, Remete-rét; Pécs, Tubes.

\section{Riodinidae}

Hamearis lucina (Linnaeus, 1758) - Abaliget, Nyáras-v.; Abaliget, üdülők; Bakonya, Sás-v.; Bükkösd, Bükkösdi-v.; Bükkösd, Szentdomján; Cserkút, Cserkúti-dombok; Hetvehely, Bükkösdi-v.; Orfü, Cigány-h.; Pécs, Árpád-tető; Pécs, Éger-v.; Pécs, Mecsekszentkút, Szunyola; Pécs, Tubes.

\section{Lycaenidae}

Lycaena dispar rutila Werneburg, 1864 (= Thersamonia d.) - Abaliget, Nyáras-v.; Bakonya, Sás-v.; Bükkösd, Szentdomján; Cserkút, Cserkúti-dombok; Cserkút, DK; Mánfa, Nagy-Mély-v.; Pécs, Árpád-tető.

Lycaena phlaeas (Linnaeus, 1761) - Abaliget, Nyáras-v.; Bakonya, Nagy-Rege; Bükkösd, Szentdomján; Cserkút, Cserkúti-dombok; Cserkút, DK; Kővágószőlős, Kajdács-dűlő; Kővágótöttös, Bicsérdi-vízf.; Pécs, Árpád-tető; Pécs, Deindol; Pécs, Éger-v.; Pécs, Mecsekszentkút, Szunyola; Pécs, Tubes.

Lycaena thersamon (Esper, 1784) (= Thersamonia t.) - Abaliget, üdülök; Pécs, Deindol; Pécs, Tubes.

Lycaena tityrus (Poda, 1761) (= Loweia t.) - Abaliget, Nyáras-v.; Bakonya, Nagy-Rege; Bükkösd, Bükkösdi-v.; Cserkút, Cserkúti-dombok; Cserkút, DK; Kővágószőlős, Kajdács-dűlő; Pécs, Éger-v.; Pécs, Mecsekszentkút, Szunyola. 
Neozephyrus quercus (Linnaeus, 1758) (= Thecla qu., Quercusia qu.) - Bakonya, Nagy-Rege; Bükkösd, Bükkösdi-v.; Cserkút, Cserkúti-dombok; Cserkút, DK; Hetvehely, Bükkösdi-v.; Pécs, Árpád-tető; Pécs, Deindol; Pécs, Éger-v.; Pécs, Tubes.

Thecla betulae (Linnaeus, 1758) - Pécs, Deindol; Pécs, Éger-v.; Pécs, Mecsekszentkút, erdészház; Pécs, Mecsekszentkút, Szunyola; Pécs, Remete-rét; Pécs, Tubes.

Callophrys rubi (Linnaeus, 1758) - Bakonya, Nagy-Rege; Bükkösd, Bükkösdi-v.; Cserkút, Cserkútidombok; Cserkút, DK; Hetvehely, Bükkösdi-v.; Kővágótöttös, Cserma-h.; Pécs, Árpád-tető; Pécs, Deindol; Pécs, Éger-v.; Pécs, Mecsekszentkút, erdészház; Pécs, Mecsekszentkút, Szunyola; Pécs, Remete-rét; Pécs, Tubes.

Satyrium w-album (Knoch, 1782) (= Strymon w.) - Mánfa, Nagy-Mély-v.; Orfü, Cigány-h.; Pécs, Árpádtető; Pécs, Éger-v.; Pécs, Remete-rét.

Satyrium pruni (Linnaeus, 1758) - Abaliget, Nyáras-v.; Pécs, Deindol.

Satyrium spini ([Denis \& Schiffermüller], 1775) (=Strymon s.) - Bükkösd, Bükkösdi-v.; Pécs, Árpád-tető; Pécs, Deindol; Pécs, Éger-v.; Pécs, Tubes.

Satyrium ilicis (Esper, 1779) (= Strymon i.) - Bükkösd, Szentdomján; Pécs, Árpád-tető; Pécs, Deindol; Pécs, Éger-v.; Pécs, Mecsekszentkút, Szunyola; Pécs, Tubes.

Satyrium acaciae (Fabricius, 1787) (= Strymon a.) - Bükkösd, Bükkösdi-v.; Cserkút, Cserkúti-dombok; Cserkút, DK; Pécs, Árpád-tető; Pécs, Remete-rét; Pécs, Tubes.

Lampides boeticus (Linnaeus, 1767) - Pécs, Deindol.

Celastrina argiolus (Linnaeus, 1758) - Bakonya, Nagy-Rege; Bükkösd, Bükkösdi-v.; Bükkösd, Szentdomján; Cserkút, DK; Hetvehely, Bükkösdi-v.; Mánfa, Nagy-Mély-v.; Orfü, Cigány-h.; Pécs, Árpád-tető; Pécs, Deindol; Pécs, Éger-v.; Pécs, Mecsekszentkút, erdészház; Pécs, Mecsekszentkút, Szunyola; Pécs, Remete-rét; Pécs, Tubes.

Cupido minimus (Fuessly, 1775) - Bakonya, Sás-v.; Pécs, Mecsekszentkút, Szunyola; Pécs, Tubes.

Cupido argiades (Pallas, 1771) (= Everes a.) - Abaliget, üdülök; Bakonya, Nagy-Rege; Bükkösd, Bükkösdi-v.; Cserkút, Cserkúti-dombok; Hetvehely, Bükkösdi-v.; Mánfa, Nagy-Mély-v.; Pécs, Árpád-tető; Pécs, Deindol; Pécs, Éger-v.; Pécs, Mecsekszentkút, Szunyola; Pécs, Remete-rét; Pécs, Tubes.

Cupido alcetas (Hoffmannsegg, 1804) (= Everes a.) - Abaliget, Nyáras-v.; Abaliget, üdülők; Bakonya, Sás-v.; Hetvehely, Bükkösdi-v.; Pécs, Árpád-tető; Pécs, Éger-v.

Cupido decolorata (Staudinger, 1886) (=Everes d.) - Abaliget, Nyáras-v.; Bakonya, Sás-v.; Cserkút, Cserkúti-dombok; Hetvehely, Bükkösdi-v.; Mánfa, Nagy-Mély-v.; Pécs, Árpád-tető; Pécs, Deindol; Pécs, Éger-v.; Pécs, Tubes.

Pseudophilotes schiffermuelleri (Hemming, 1929) (= Philotes vicrama (Moore, 1865)) - Cserkút, DK; Pécs, Deindol; Pécs, Tettye; Pécs, Tubes.

Iolana iolas (Ochsenheimer, 1816) - Pécs, Deindol; Pécs, Tettye; Pécs, Tubes.

Glaucopsyche alexis (Poda, 1761) - Bakonya, Nagy-Rege; Hetvehely, Bükkösdi-v.; Pécs, Árpád-tető; Pécs, Deindol; Pécs, Éger-v.; Pécs, Remete-rét; Pécs, Tettye; Pécs, Tubes.

Plebeius argus (Linnaeus, 1758) - Abaliget, Nyáras-v.; Abaliget, üdülök; Bakonya, Sás-v.; Bükkösd, Bükkösdi-v.; Cserkút, Cserkúti-dombok; Cserkút, DK; Hetvehely, Bükkösdi-v.; Kővágótöttös, Bicsérdi-vízf.; Pécs, Árpád-tető; Pécs, Deindol; Pécs, Éger-v.; Pécs, Remete-rét; Pécs, Tubes.

Plebeius argyrognomon (Bergsträsser, 1779) (= Lycaeides a.) - Bükkösd, Szentdomján; Mánfa, NagyMély-v.; Pécs, Árpád-tető; Pécs, Tubes.

Aricia agestis ([Denis \& Schiffermüller], 1775) - Bakonya, Nagy-Rege; Cserkút, Cserkúti-dombok; Hetvehely, Bükkösdi-v.; Kővágószőlős, Kajdács-dűlő; Kővágótöttös, Bicsérdi-vízf.; Pécs, Deindol; Pécs, Éger-v.; Pécs, Mecsekszentkút, Szunyola; Pécs, Tubes.

Cyaniris semiargus (Rottemburg, 1775) - Abaliget, Nyáras-v.; Bakonya, Sás-v.; Cserkút, DK; Pécs, Árpádtető; Pécs, Mecsekszentkút, Szunyola; Pécs, Remete-rét; Pécs, Tubes.

Polyommatus icarus (Rottemburg, 1775) - Abaliget, Nyáras-v.; Abaliget, üdülők; Bakonya, Nagy-Rege; Bakonya, Sás-v.; Bükkösd, Bükkösdi-v.; Bükkösd, Szentdomján; Cserkút, Cserkúti-dombok; Cserkút, DK; Hetvehely, Bükkösdi-v.; Kövágószőlős, Kajdács-dülő; Kővágótöttös, Bicsérdi-vízf.; Mánfa, Nagy-Mély-v.; 
Orfü, Cigány-h.; Pécs, Árpád-tető; Pécs, Deindol; Pécs, Éger-v.; Pécs, Mecsekszentkút, erdészház; Pécs, Mecsekszentkút, Szunyola; Pécs, Remete-rét; Pécs, Tubes.

Polyommatus dorylas ([Denis \& Schiffermüller], 1775) (= Lysandra hylas) - Pécs, Tubes.

Polyommatus daphnis ([Denis \& Schiffermüller], 1775) (= Meleageria d.) - Pécs, Deindol; Pécs, Éger-v.; Pécs, Tubes.

Polyommatus bellargus (Rottemburg, 1775) (= Lysandra b.) - Abaliget, Nyáras-v.; Bükkösd, Bükkösdi-v.; Bükkösd, Szentdomján; Cserkút, Cserkúti-dombok; Cserkút, DK; Hetvehely, Bükkösdi-v.; Kővágószőlős, Kajdács-dűlő; Kővágótöttös, Bicsérdi-vízf.; Pécs, Árpád-tető; Pécs, Deindol; Pécs, Remete-rét; Pécs, Tubes.

\section{Nymphalidae}

Libytheinae

Libythea celtis (Laicharting, 1782) - Cserkút, vízmü környék; Pécs, Deindol.

\section{Limenitinae}

Limenitis reducta Staudinger, 1901 - Pécs, Árpád-tető; Pécs, Deindol; Pécs, Tettye; Pécs, Tubes.

Neptis rivularis (Scopoli, 1763) - Abaliget, üdülők; Pécs, Árpád-tető; Pécs, Deindol; Pécs, Éger-v.; Pécs, Mecsekszentkút, Szunyola; Pécs, Tettye; Pécs, Tubes.

Neptis sappho (Pallas, 1771) (= N. hylas, N. aceris) - Abaliget, üdülök; Bakonya, Sás-v.; Cserkút, Cserkútidombok; Hetvehely, Bükkösdi-v.; Mánfa, Nagy-Mély-v.; Orfü, Cigány-h.; Pécs, Árpád-tető; Pécs, Deindol; Pécs, Éger-v.; Pécs, Mecsekszentkút, Szunyola; Pécs, Mecsekszentkút, erdészház; Pécs, Tubes.

\section{Heliconiinae}

Argynnis paphia (Linnaeus, 1758) - Abaliget, üdülők; Bakonya, Nagy-Rege; Bükkösd, Bükkösdi-v.; Cserkút, Cserkúti-dombok; Mánfa, Nagy-Mély-v.; Orfü, Cigány-h.; Pécs, Árpád-tető; Pécs, Deindol; Pécs, Éger-v.; Pécs, Mecsekszentkút, Szunyola; Pécs, Remete-rét; Pécs, Tubes.

Argynnis adippe ([Denis \& Schiffermüller], 1775) (=Fabriciana berecynthia) - Bükkösd, Bükkösdi-v.; Cserkút, Cserkúti-dombok; Mánfa, Nagy-Mély-v.; Orfü, Cigány-h.; Pécs, Deindol; Pécs, Mecsekszentkút, Szunyola.

Argynnis aglaja (Linnaeus, 1758) (= Mesoacidalia a.) - Mánfa, Nagy-Mély-v.; Orfü, Cigány-h.; Pécs, Árpád-tető; Pécs, Éger-v.; Pécs, Mecsekszentkút, Szunyola; Pécs, Remete-rét; Pécs, Tubes.

Issoria lathonia (Linnaeus, 1758) - Bakonya, Nagy-Rege; Bakonya, Sás-v.; Bükkösd, Bükkösdi-v.; Bükkösd, Szentdomján; Cserkút, Cserkúti-dombok; Cserkút, DK; Hetvehely, Bükkösdi-v.; Kővágószőlős, Kajdács-dűlő; Kővágótöttös, Bicsérdi-vízf.; Mánfa, Nagy-Mély-v.; Pécs, Árpád-tető; Pécs, Deindol; Pécs, Éger-v.; Pécs, Mecsekszentkút, Szunyola; Pécs, Remete-rét; Pécs, Tubes.

Brenthis daphne ([Denis \& Schiffermüller], 1775) - Bükkösd, Bükkösdi-v.; Bükkösd, Szentdomján; Cserkút, Cserkúti-dombok; Cserkút, DK; Hetvehely, Bükkösdi-v.; Pécs, Árpád-tető; Pécs, Éger-v.; Pécs, Mecsekszentkút, Szunyola.

Boloria dia (Linnaeus, 1767) (= Clossiana d.) - Bakonya, Nagy-Rege; Bükkösd, Szentdomján; Cserkút, Cserkúti-dombok; Cserkút, DK; Pécs, Árpád-tető; Pécs, Deindol; Pécs, Éger-v.; Pécs, Mecsekszentkút, erdészház; Pécs, Remete-rét; Pécs, Tubes.

Boloria euphrosyne (Linnaeus, 1758) (= Clossiana e.) - Cserkút, DK; Mánfa, Nagy-Mély-v.; Pécs, Árpád-tető. Boloria selene ([Denis \& Schiffermüller], 1775) (=Clossiana s.) - Mánfa, Nagy-Mély-v.; Pécs, Árpád-tető.

\section{Apaturinae}

Apatura ilia ([Denis \& Schiffermüller], 1775) - Abaliget, üdülők; Cserkút, Cserkúti-dombok; Pécs, Éger-v.; Pécs, Mecsekszentkút, Szunyola.

Apatura iris (Linnaeus, 1758) - Pécs, Mecsekszentkút, Szunyola. 


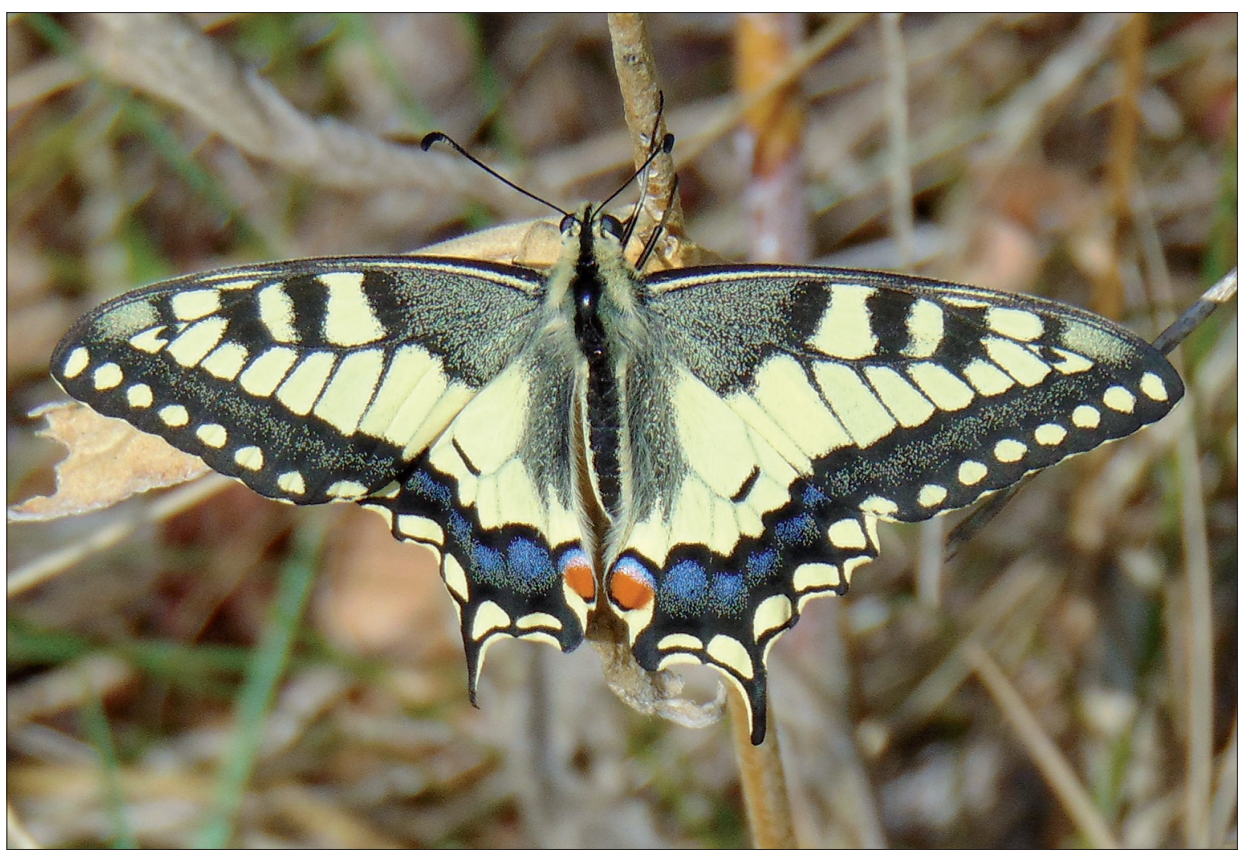

16. ábra: Papilio machaon Linnaeus, 1758

(fotó: Uherkovich Ákos)

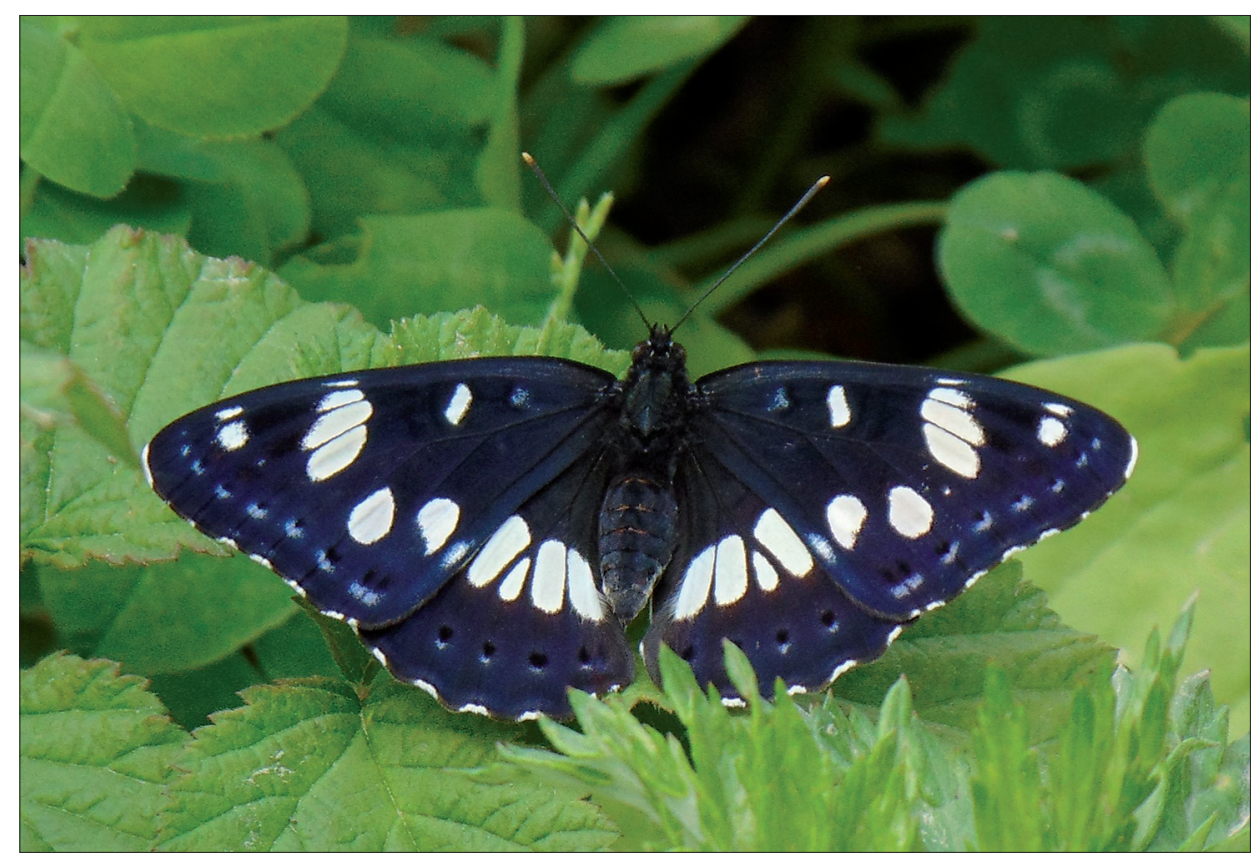

17. ábra: Limenitis reducta Staudinger, 1901

(fotó: Uherkovich Ákos) 


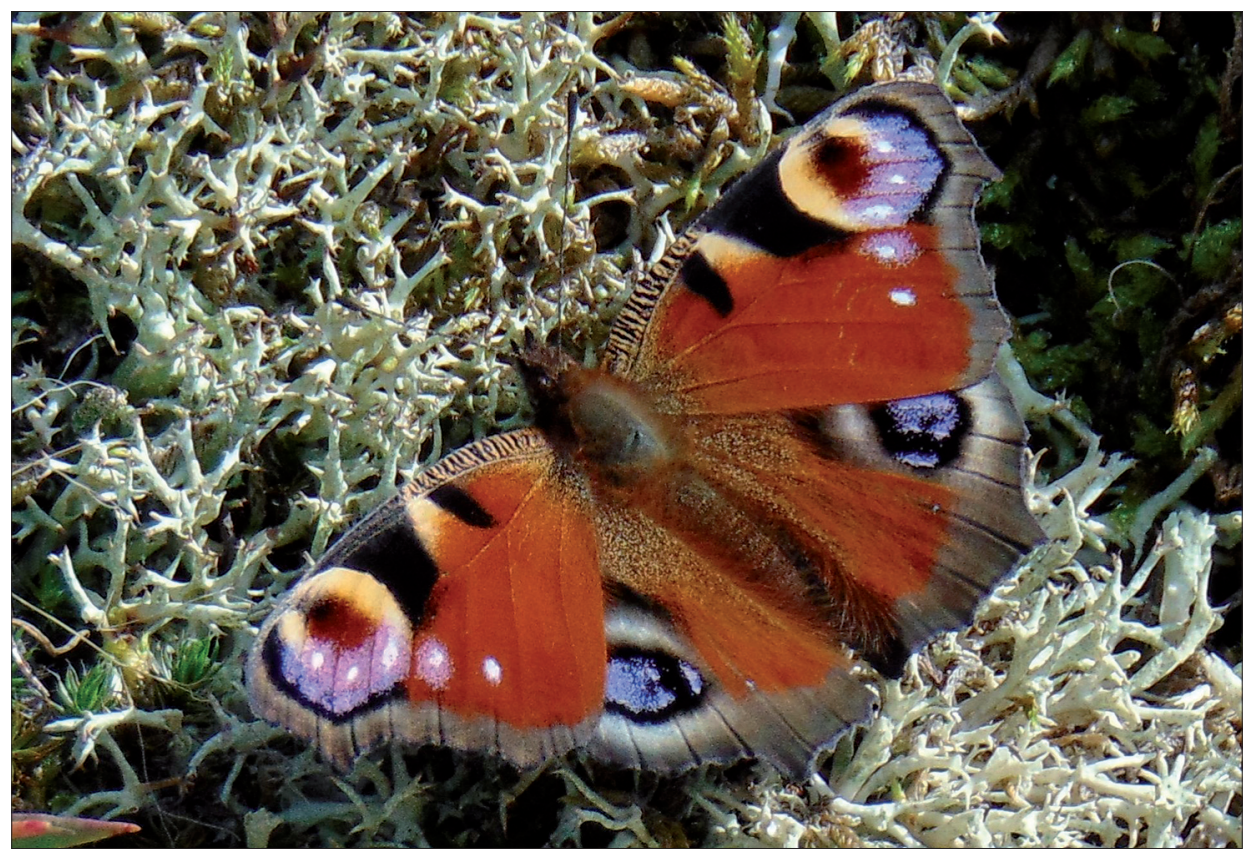

17. ábra: Nymphalis io (Linnaeus, 1758)

(fotó: Uherkovich Ákos)

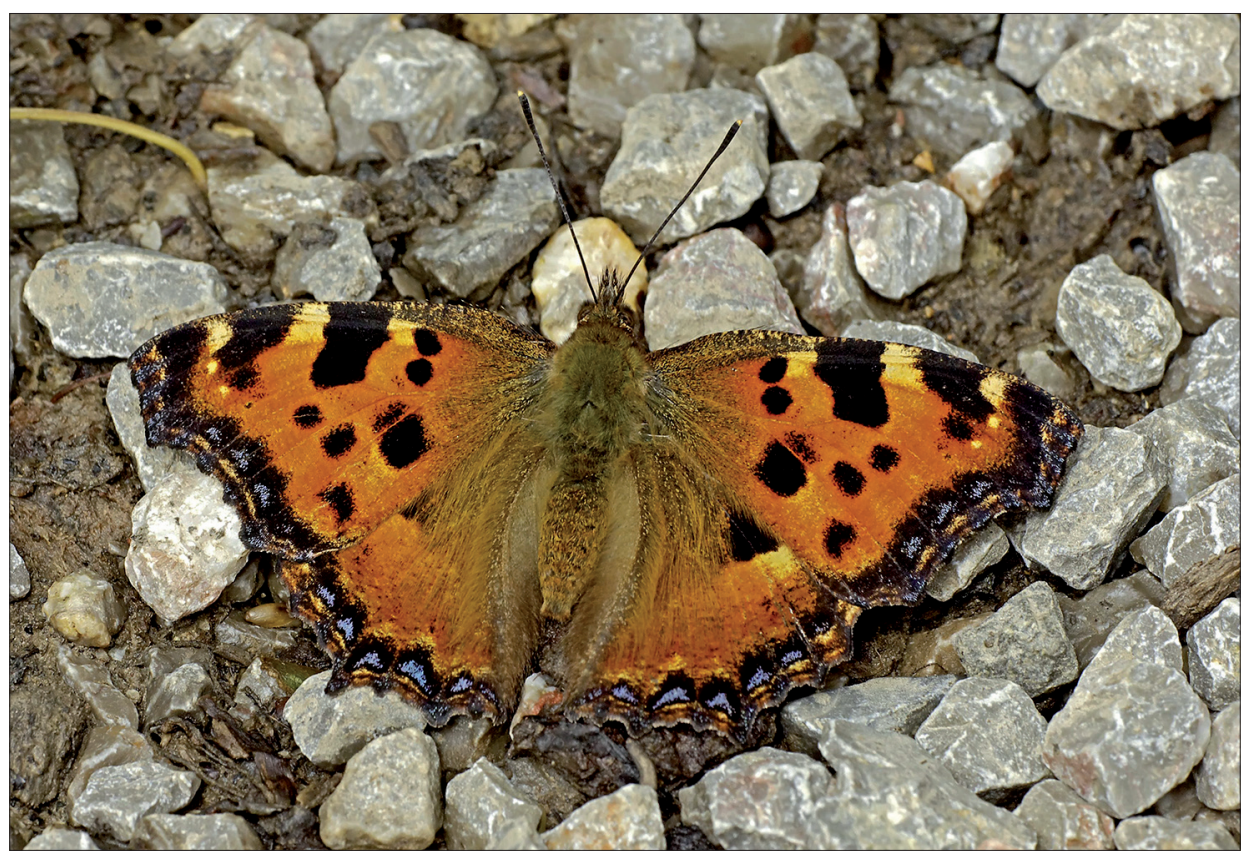

18. ábra: Nymphalis polychloros (Linnaeus, 1758)

(fotó: Ötvös Károly) 


\section{Nymphalinae}

Euphydryas maturna (Linnaeus, 1758) - Abaliget, Nyáras-v.; Bakonya, Sás-v.; Bükkösd, Bükkösdi-v.; Hetvehely, Bükkösdi-v.

Melitaea cinxia (Linnaeus, 1758) - Bükkösd, Bükkösdi-v.; Cserkút, Cserkúti-dombok; Cserkút, DK; Kővágószőlős, Kajdács-dűlő; Pécs, Tubes.

Melitaea didyma (Esper, 1778) - Abaliget, üdülök; Bakonya, Nagy-Rege; Bükkösd, Bükkösdi-v.; Cserkút, Cserkúti-dombok; Cserkút, DK; Kővágószőlős, Kajdács-dűlő; Pécs, Árpád-tető; Pécs, Éger-v.; Pécs, Remeterét; Pécs, Tubes.

Melitaea phoebe ([Denis \& Schiffermüller], 1775) - Abaliget, Nyáras-v.; Cserkút, Cserkúti-dombok; Bakonya, Nagy-Rege; Bükkösd, Bükkösdi-v.; Hetvehely, Bükkösdi-v.; Kővágószőlős, Kajdács-dủlő; Pécs, Árpád-tetö; Pécs, Deindol; Pécs, Tubes.

Melitaea trivia ([Denis \& Schiffermüller], 1775) - Bakonya, Nagy-Rege; Bükkösd, Bükkösdi-v.; Cserkút, Cserkúti-dombok; Hetvehely, Bükkösdi-v.; Pécs, Deindol; Pécs, Mecsekszentkút, Szunyola; Pécs, Tubes.

Melitaea athalia (Rottemburg, 1775) (= Mellicta a.) - Abaliget, Nyáras-v.; Abaliget, üdülök; Bakonya, NagyRege; Bakonya, Sás-v.; Bükkösd, Bükkösdi-v.; Bükkösd, Szentdomján; Cserkút, Cserkúti-dombok; Cserkút, DK; Hetvehely, Bükkösdi-v.; Kővágószőlős, Kajdács-dülő; Mánfa, Nagy-Mély-v.; Pécs, Árpád-tető; Pécs, Deindol; Pécs, Éger-v.; Pécs, Mandulás; Pécs, Mecsekszentkút, Szunyola; Pécs, Remete-rét; Pécs, Tubes.

Melitaea aurelia Nickerl, 1850 (= Mellicta a.) - Cserkút, DK; Pécs, Árpád-tető; Pécs, Remete-rét.

Araschnia levana (Linnaeus, 1758) - Abaliget, Nyáras-v.; Abaliget, üdülök; Bükkösd, Bükkösdi-v.; Bükkösd, Szentdomján; Cserkút, Cserkúti-dombok; Hetvehely, Bükkösdi-v.; Orfü, Cigány-h.; Pécs, Árpádtető; Pécs, Éger-v.; Pécs, Mecsekszentkút, Szunyola.

Nymphalis io (Linnaeus, 1758) (= Inachis i.) - Abaliget, Nyáras-v.; Bakonya, Nagy-Rege; Bükkösd, Bükkösdi-v.; Bükkösd, Szentdomján; Cserkút, Cserkúti-dombok; Hetvehely, Bükkösdi-v.; Kővágószőlős, Kajdács-dűlő; Kővágótöttös, Bicsérdi-vízf.; Mánfa, Nagy-Mély-v.; Orfü, Cigány-h.; Pécs, Árpád-tető; Pécs, Deindol; Pécs, Éger-v.; Pécs, Keresztkunyhó; Pécs, Mecsekszentkút, erdészház; Pécs, Mecsekszentkút, Szunyola; Pécs, Tubes.

Nymphalis urticae (Linnaeus, 1758) (= Aglais u.) - Bakonya, Nagy-Rege; Bakonya, Sás-v.; Bükkösd, Bükkösdi-v.; Cserkút, DK; Kővágótöttös, Cserma-h.; Mánfa, Nagy-Mély-v.; Orfü, Cigány-h.; Pécs, Árpádtető; Pécs, Deindol; Pécs, Éger-v.; Pécs, Tubes.

Nymphalis polychloros (Linnaeus, 1758) - Abaliget, Nyáras-v.; Abaliget, üdülők; Bükkösd, Bükkösdi-v.; Bükkösd, Szentdomján; Cserkút, Cserkúti-dombok; Cserkút, DK; Kővágószőlös, Kajdács-dűlő; Kővágótöttös, Bicsérdi-vízf.; Orfü, Cigány-h.; Pécs, Árpád-tető; Pécs, Deindol; Pécs, Éger-v.; Pécs, Keresztkunyhó; Pécs, Mecsekszentkút, Szunyola; Pécs, Tubes.

Nymphalis antiopa (Linnaeus, 1758) (= Euvanessa a.) - Abaliget, Nyáras-v.; Bükkösd, Bükkösdi-v.; Hetvehely, Bükkösdi-v.; Pécs, Árpád-tető; Pécs, Deindol; Pécs, Éger-v.; Pécs, Mecsekszentkút, Szunyola.

Nymphalis c-album (Linnaeus, 1758) (= Polygonia c.) - Abaliget, Nyáras-v.; Abaliget, üdülök; Bakonya, Nagy-Rege; Bükkösd, Bükkösdi-v.; Cserkút, Cserkúti-dombok; Hetvehely, Bükkösdi-v.; Kővágótöttös, Bicsérdi-vízf.; Mánfa, Nagy-Mély-v.; Orfü, Cigány-h.; Pécs, Árpád-tető; Pécs, Deindol; Pécs, Éger-v.; Pécs, Mecsekszentkút, Szunyola; Pécs, Tubes.

Vanessa atalanta (Linnaeus, 1758) - Abaliget, üdülök; Bakonya, Nagy-Rege; Bükkösd, Bükkösdi-v.; Cserkút, Cserkúti-dombok; Hetvehely, Bükkösdi-v.; Kővágószőlős, Kajdács-dűlő; Kővágótöttös, Bicsérdivízf.; Mánfa, Nagy-Mély-v.; Pécs, Árpád-tető; Pécs, Deindol; Pécs, Éger-v.; Pécs, Mecsekszentkút, Szunyola; Pécs, Tettye; Pécs, Tubes.

Vanessa cardui (Linnaeus, 1758) (= Cynthia c.) - Bakonya, Nagy-Rege; Bükkösd, Bükkösdi-v.; Bükkösd, Szentdomján; Cserkút, Cserkúti-dombok; Cserkút, DK; Hetvehely, Bükkösdi-v.; Kővágószőlös, Kajdács-dülö; Pécs, Árpád-tető; Pécs, Deindol; Pécs, Éger-v.; Pécs, Keresztkunyhó; Pécs, Mecsekszentkút, Szunyola; Pécs, Tubes.

\section{Satyrinae}

Pararge aegeria tircis (Godart, 1821) - Abaliget, Nyáras-v.; Bakonya, Nagy-Rege; Bakonya, Sás-v.; Bükkösd, Bükkösdi-v.; Bükkösd, Szentdomján; Cserkút, Cserkúti-dombok; Kővágótöttös, Bicsérdi-vízf.; Mánfa, Nagy-Mély-v.; Orfü, Cigány-h.; Pécs, Árpád-tető; Pécs, Deindol; Pécs, Éger-v.; Pécs, Mecsekszentkút, erdészház; Pécs, Mecsekszentkút, Szunyola; Pécs, Remete-rét; Pécs, Tettye; Pécs, Tubes. 
Lasiommata megera (Linnaeus, 1767) - Bakonya, Nagy-Rege; Bakonya, Sás-v.; Bükkösd, Bükkösdi-v.; Bükkösd, Szentdomján; Cserkút, Cserkúti-dombok; Cserkút, DK; Hetvehely, Bükkösdi-v.; Kővágószőlős, Kajdács-dűlő; Kővágótöttös, Cserma-h.; Pécs, Árpád-tető; Pécs, Deindol; Pécs, Éger-v.; Pécs, Mecsekszentkút, erdészház; Pécs, Mecsekszentkút, Szunyola; Pécs, Remete-rét; Pécs, Tubes.

Lasiommata maera (Linnaeus, 1758) - Abaliget, Nyáras-v.; Bakonya, Nagy-Rege; Bakonya, Sás-v.; Bükkösd, Bükkösdi-v.; Bükkösd, Szentdomján; Cserkút, Cserkúti-dombok; Hetvehely, Bükkösdi-v.; Kővágótöttös, Cserma-h.; Mánfa, Nagy-Mély-v.; Pécs, Árpád-tető; Pécs, Deindol; Pécs, Éger-v.; Pécs, Mecsekszentkút, Szunyola; Pécs, Tubes.

Coenonympha arcania (Linnaeus, 1761) - Abaliget, Nyáras-v.; Bakonya, Nagy-Rege; Bakonya, Sás-v.; Bükkösd, Bükkösdi-v.; Bükkösd, Szentdomján; Cserkút, Cserkúti-dombok; Cserkút, DK; Hetvehely, Bükkösdi-v.; Kővágószőlős, Kajdács-dűlő; Kővágótöttös, Cserma-h.; Mánfa, Nagy-Mély-v.; Pécs, Árpád-tető; Pécs, Deindol; Pécs, Éger-v.; Pécs, Mecsekszentkút, Szunyola; Pécs, Remete-rét; Pécs, Tubes.

Coenonympha glycerion (Borkhausen, 1788) (= iphis ([Denis \& Schiffermüller], 1775)) - Abaliget, Nyáras-v.; Bakonya, Nagy-Rege; Bakonya, Sás-v.; Bükkösd, Bükkösdi-v.; Bükkösd, Szentdomján; Cserkút, Cserkútidombok; Cserkút, DK; Kővágótöttös, Cserma-h.; Mánfa, Nagy-Mély-v.; Pécs, Árpád-tető; Pécs, Remete-rét; Pécs, Tubes.

Coenonympha pamphilus (Linnaeus, 1758) - Abaliget, Nyáras-v.; Bakonya, Nagy-Rege; Bakonya, Sás-v.; Bükkösd, Bükkösdi-v.; Bükkösd, Szentdomján; Cserkút, Cserkúti-dombok; Cserkút, DK; Hetvehely, Bükkösdi-v.; Kővágószőlős, Kajdács-dűlő; Kővágótöttös, Bicsérdi-vízf.; Mánfa, Nagy-Mély-v.; Pécs, Árpádtető; Pécs, Deindol; Pécs, Éger-v.; Pécs, Mecsekszentkút, erdészház; Pécs, Mecsekszentkút, Szunyola; Pécs, Remete-rét; Pécs, Tubes.

Pyronia tithonus (Linnaeus, 1767) - Bakonya, Nagy-Rege; Cserkút, Cserkúti-dombok; Cserkút, DK; Pécs, Deindol; Pécs, Éger-v.; Pécs, Mecsekszentkút, Szunyola.

Aphantopus hyperantus (Linnaeus, 1758) - Abaliget, üdülök; Cserkút, Cserkúti-dombok; Hetvehely, Bükkösdi-v.; Mánfa, Nagy-Mély-v.; Pécs, Árpád-tető; Pécs, Deindol; Pécs, Éger-v.; Pécs, Mecsekszentkút, Szunyola; Pécs, Remete-rét; Pécs, Tubes.

Maniola jurtina (Linnaeus, 1758) - Abaliget, Nyáras-v.; Abaliget, üdülök; Bakonya, Nagy-Rege; Bakonya, Sás-v.; Bükkösd, Bükkösdi-v.; Cserkút, Cserkúti-dombok; Cserkút, DK; Hetvehely, Bükkösdi-v.; Kővágószőlős, Kajdács-dűlő; Kővágótöttös, Cserma-h.; Mánfa, Nagy-Mély-v.; Orfü, Cigány-h.; Pécs, Árpád-tető; Pécs, Deindol; Pécs, Éger-v.; Pécs, Mecsekszentkút, Szunyola; Pécs, Remete-rét; Pécs, Tubes.

Melanargia galathea (Linnaeus, 1758) - Bükkösd, Bükkösdi-v.; Cserkút, Cserkúti-dombok; Cserkút, DK; Hetvehely, Bükkösdi-v.; Kővágószőlős, Kajdács-dűlő; Mánfa, Nagy-Mély-v.; Pécs, Árpád-tető; Pécs, Deindol; Pécs, Éger-v.; Pécs, Mandulás; Pécs, Mecsekszentkút, Szunyola; Pécs, Remete-rét; Pécs, Tubes.

Minois dryas (Scopoli, 1763) - Abaliget, üdülök; Bakonya, Nagy-Rege; Bükkösd, Bükkösdi-v.; Cserkút,

Cserkúti-dombok; Cserkút, DK; Hetvehely, Bükkösdi-v.; Mánfa, Nagy-Mély-v.; Pécs, Árpád-tető; Pécs,

Deindol; Pécs, Éger-v.; Pécs, Mecsekszentkút, Szunyola; Pécs, Remete-rét; Pécs, Tubes.

Hipparchia fagi (Scopoli, 1763) - Bakonya, Nagy-Rege; Cserkút, Cserkúti-dombok; Cserkút, DK; Hetvehely, Bükkösdi-v.; Pécs, Deindol; Pécs, Éger-v.; Pécs, Mecsekszentkút, Szunyola; Pécs, Tubes.

Arethusana arethusa ([Denis \& Schiffermüller], 1775) - Cserkút, DK; Pécs, Éger-v.; Pécs, Remete-rét; Pécs, Tubes.

Brintesia circe (Fabricius, 1775) - Bakonya, Nagy-Rege; Bükkösd, Bükkösdi-v.; Cserkút, Cserkútidombok; Cserkút, DK; Hetvehely, Bükkösdi-v.; Pécs, Árpád-tető; Pécs, Deindol; Pécs, Éger-v.; Pécs, Mecsekszentkút, Szunyola; Pécs, Tubes. 


\section{Megvitatás}

\section{A fauna általános jellemzése}

A tájvédelmi körzet teljes területén az elmúlt fél évszázadban végzett felméréseim eddig 763 fajt eredményeztek. Ezek megoszlása családonként a következő módon alakult (1. táblázat):

1. táblázat: A fajok száma a Nyugat-Mecsek TK-ban, családonként

\begin{tabular}{|l|c|l|c|}
\hline Család & fajszám & Család & fajszám \\
\hline Lasiocampidae & 14 & Nolidae & 16 \\
\hline Sphingidae & 13 & Noctuidae & 248 \\
\hline Saturniidae & 4 & Hesperiidae & 13 \\
\hline Drepanidae & 6 & Papilionidae & 4 \\
\hline Thyatiridae & 8 & Pieridae & 13 \\
\hline Geometridae & 241 & Riodinidae & 1 \\
\hline Notodontidae & 28 & Lycaenidae & 29 \\
\hline Erebidae & 83 & Nymphalidae & 40 \\
\hline Eutelidae & 1 & Összesen: & 763 \\
\hline
\end{tabular}

A magas fajszám a változatos környezeti feltételek következménye, de emellett természetesen a rendszeres és kitartó gyüjtőmunka is szükséges volt hozzá. Például a DunaDráva Nemzeti park Dráva menti területeiről - ugyancsak sok ponton végzett rendszeres munka eredményeképpen 775 fajt ismerünk (ÁвRAHÁm, UHERKOVICH 1998), de ezen belül csupán az egykori Barcsi Tájvédelmi körzetböl 712 faj vált ismertté (UHERKOVICH 1985). A kis kiterjedésü, de igen alaposan kutatott Villányi-hegységből 724 fajt mutattak ki (ÁBRAHÁm, UHERKOVICH 2000).

Mint mindenhol, itt is a nagy elterjedésü, széles ökológiai spektrumú fajok száma a legmagasabb, mennyiségi arányuk (dominanciájuk) pedig meghatározó.

\section{Védett fajok}

Az elmúlt mintegy 50 év alatt kimutatott 763 nagylepke-faj közel tizede, 74 faj áll törvényes védelem alatt (Magyar Közlöny 2015) (2. táblázat). Ezen belül két olyan faj is van, amelyek fokozottan védettek, ezek az Arytrura musculus és a Iolana iolas.

Az Arytrura musculus ismert „klasszikus” lelőhelye a Kis-Balatonon volt, ahol mintegy 7-8 évtizede fogták (Kovács 1953). Később ismertté vált Bátorligetről, valamint Tihanyból és Debrecenből. Néhány évtizednek el kellett telnie, míg újabb helyeken bukkant fel a kilencvenes években, ekkor kiterjedtebb kelet-magyarországi populációit fedezték fel, valamint egy állandóan müködő erdészeti fénycsapda a Baranya megyei Sumonyban fogta a kilencvenes években, több alkalommal (NÉMETH, SZABóKY 1998). A Nyírség déli részén több helyröl számos példánya került elő az ezredforduló környékén (BARANYI 2003). A kétezres években a Dél-Dunántúlon több helyen mutatták ki, például a korábban igen alaposan kutatott Barcsi Tájvédelmi körzetben (MALGAY, BRUnNER 2011). Ezek után talán már nem is volt különösebben meglepő, hogy megfogtuk a DélZselicben (UHERKOVICH, ÁBRAHÁm 2007), valamint a Nyugat-Mecsek Tájvédelmi körzet két pontjáról került elő: 
Cserkúton 2007. július 5-én fényre jött két példánya, számára eléggé alkalmatlannak tünő száraz cseres-tölgyes szomszédságában, kökény-galagonya bozót tisztásán. A gyüjtőhely közelében, néhány száz méterre öreg füzfák tenyésznek a Cserkúti-patak völgyében, talán ott fejlődtek a hernyók. Egy példányát újabban, 2015. július 4-én Abaligeten fényképezte le Ötvös Károly (8. ábra).

A fentiek mellett előkerült még Pécs déli részén, a Nagypostavölgyben is, itt 2008. június 4-én gyűjtötte Gergely Tibor. Ez utóbbi gyüjtőhelytől északra, a völgyfenéken kiterjedtebb füzes van. Még újabban a Dráva mentén, a cún-szaporcai holt-Dráva partján találkoztunk vele (2017. július 17.), ártéri ligeterdőben. Utóbbi négy előfordulása (Cserkút, Abaliget, Pécs-Nagypostavölgy, Szaporca) eddig publikálatlan volt.

A Iolana iolas a Pécs feletti, délies lejtőkön 50-60 éve igen gyakori volt. Azóta a számára alkalmas élöhelyek - azaz tápnövénye, a Colutea arborescens termőhelyei - erösen összezsugorodtak, részben a város terjeszkedése (déli lejtő kertjei, szőlöi közül sok beépült), részben pedig a Misina-Tubes vonulat délnyugati lejtői és a Tettye környéke erdőtisztásainak beerdősülése miatt. Bár a lepkék manapság is rendszeresen láthatók például a Deindolokban - itt elhagyott szőlőkben sokfelé tenyészik a tápnövény - de az egyedszám erősen csökkent. A Tettye környékén évtizedek óta nem láttam, és nagyon megritkult a Tubes-láb kisebb tisztásain is.

A védett fajok többségét egyenként nem jellemezhetjük nagy számuk miatt, mivel ezt a dolgozat terjedelme nem teszi lehetővé. Az általánosan elterjedt és - legalábbis egyelöre - viszonylag gyakori fajokról nem érdemes említést tenni. Bár évtizedekkel ezelött senki sem hitte volna, hogy a Nymphalis urticae miatt aggódnunk kellene, napjainkra gyakorlatilag eltünt. Több más védett faj is nagyon megritkult, vagy teljesen eltünt, legalábbis a Nyugati-Mecsek területéről, mint például az Acherontia atropos, Saturnia pyri (10. ábra), Dicranura ulmi, Ocnogyna parasita, Leptidea morsei major, Zerynthia polyxena, Lycaena thersamon, Satyrium w-album, Pseudophilotes schiffermuelleri, Limenitis reducta (16. ábra) vagy az Arethusana arethusa. A védett fajok közül továbbiakat lehetne felsorolni itt, a védettséget nem élvezők közül szintén sokat nem láttunk itt évtizedek óta.

Egyes védett fajok csak egyetlen alkalommal kerültek elő, annak ellenére, hogy számos ponton - a következő felsorolt fajok élöhelyén is - rendszeres mintavételek, gyüjtések, megfigyelések voltak. Az Entephria caesiata egyetlen példánya a mánfai Kőlyuknál jött fényre, egyébként országosan is kivételesen ritkán fordul elő. Ugyanakkor a Dyscia conspersaria - amelynek egyetlen példányát a pécsi Tettyén fogtam még a hetvenes években - a szomszédos Villányi-hegységben még nem volt ritka mintegy 30 éve. Szintén egyetlen példányát láttuk a Periphanes delphinii fajnak.

Ezzel szemben több olyan, korlátozott elterjedése vagy populációinak veszélyeztetettsége miatt védelemben részesülö fajunk van, amelyek egyelöre még rendszeresen elöfordulnak a tájvédelmi körzet területén.

Az elsősorban melegkedvelő tölgyesekben és molyhostölgyesekben élő, ezért viszonylag korlátozott elterjedésü Marumba quercus (9. ábra) az elmúlt években sem volt ritka: rajzási idejében rendszeresen és többfelé megfigyelhettük. Hasonlóan a látványos küllemü Phalera bucephaloides (13. ábra), amely egyik lelöhelyén - Pécs, Mecsekszentkút, Szunyola - kifejezetten gyakori, sőt időnként tömeges volt. A korábbi szakirodalomban - amelyet itt nem részletezek -, ritkán említett Perconia strigillaria a tájvédelmi körzetben (és attól északra, a Zselicben is) kifejezetten gyakori, rajzási ideje alatt csaknem mindenütt nagyobb számban látható, sőt, nappal is könnyen felzavarható az aljnövényzetből.

Az utóbbi évtizedekben többnyire csak a Mecsekben észlelt Diaphora luctuosa kis számban ugyan, de szinte évről-évre megjelenik, a Deindolokban április folyamán a legutóbbi években is láttuk egy-egy példányát. A Iolana iolas ugyancsak nem ritka ott, ahol tápnövénye is tenyészik. 
Az alig több mint két évtizede leírt Shargacucullia gozmanyi G. \& L. Ronkay 1994 a Bükkből, a Dunántúli-középhegységböl, majd a Villányi-hegységből vált ismertté (ÁBrAHÁm, UHERKovich 2000). Azóta több újabb lelőhelye ismertté vált, de eddig még nem rajzolódott ki pontosan elterjedési területe a közelrokon fajokkal mutatott hasonlósága miatt. Mivel fényre csak nagyon gyengén reagál, ezért inkább hernyóit érdemes tápnövényén (Verbascum phoenicem) keresni.

A fokozott nedvességigényü Proserpinus proserpina (Pallas, 1772) néhány példánya ugyan szárazabb élőhelyeken is elökerült, de alapvetően itt is a kissé nedvesebb helyek egyre ritkuló állata. A tájvédelmi körzet völgyeiben várható újabb előkerülése.

Tapasztalataim szerint az elmúlt évtizedek folyamán gyakoribbá vált például az Euphydryas maturna, Satyrium pruni, Drymonia velitaris vagy Melitaea trivia. A gyakoriság növekedése a védett fajokon belül inkább kivételnek számít.

Más fajok eltüntek, majd újra megjelentek, azaz évtizedekig nem vagy alig fogtuk öket, napjainkban ismét számos példányukat észleltük. Egyik ilyen faj a Polypogon gryphalis (Láperdei karcsúbagoly), amely Bakonya körül, több ponton újabban ismét előkerült, előtte évtizedekig sehol sem láttuk, meg általában is nagyon kevés ismert elterjedési adata volt.

Több védett faj - pl. Aglia tau (11. ábra), Euplagia quadripunctaria, Autographa jota, Gonepteryx rhamni, Neptis sappho, Argynnis paphia, Brenthis daphne, Nymphalis io (12. ábra), Nymphalis polychloros (18. ábra) vagy Pyronia tithonus - a tájvédelmi körzet területén korábban is gyakori volt (természetesen csak a számukra alkalmas biotópokban), napjainkban is nagyobb számban láthatók, így ezek nem tünnek veszélyeztetettnek.

A korábbi szakirodalom két további fokozottan védett faj mecseki előfordulását is említi. Az Erannis ankeraria az ötvenes évek első felében a mai nevén Hotel Kikelet szállótól nyugatra fordult elő. Ugyanazon a helyen a nyolcvanas években rajzási idejében gyüjtöttem ott, de ez a faj másutt sem kerül elö.

A Cucullia formosa Rogenhofer, 1860 50-60 éve még élt a Tubesen. Lehetséges, hogy még ma is tenyészik ott, mindenesetre a fényre kevéssé reagáló imágóját nem láttam, a hernyót pedig nem kerestem.

\section{Egyéb ritka és jellemzö fajok}

Az Aedia leucomelas a magyar fauna új faja - amelynek első példányai a kilencvenes években kerültek elő - a Mecseken is meghonosodott, és nem nagy számban, de többször és többfelé előkerült a kilencvenes évek közepétől kezdve. A szomszédos Villányihegységben fogtuk elöször (ÁBRAHÁM, UHERKOVICH 2000).

Hypoxystis pluviaria (Fabricius, 1787). Nyugat-Magyarországon elterjedt és gyakori, délkelet felé haladva gyakorisága erösen csökken. Baranyában fogták a Villányihegységben is (ÁBrAHÁM, UHERKOVICH 2000), majd a tájvédelmi körzet nyugati peremén is kimutattuk.

Nem kifejezetten a Cerura erminea (Esper, 1783) számára alkalmasak a tájvédelmi körzet élőhelyei. Míg például eléggé gyakorinak bizonyult a Dráva menti ligeterdőkben (Uherkovich, ÁbrAHÁm 1995), nem ritka a dél-baranyai keményfájú ligeterdőkben (Gilvánfa, Kisdobsza: UHERKOVICH 1977, 1990), ugyanakkor korábban jelentős számban észleltem egy homoki fehérnyárasban a Duna-Tisza-közi Ásotthalomnál. A NyugatMecsekben ritka, ötven év alatt mindössze három helyen fogtuk egy-két példányát.

A Lycia pomonaria (Hübner, 1790)-t korábban a kifejezetten ritka fajok között tartották nyilván. Ebben valószínüleg az is közrejátszott, hogy rövig ideig, igen korai időpontban rajzik (sokszor már február második felében). A Nyugat-Mecsek TK-ben rendszeresen előkerült, napjainkban sem mondható ritkának, ha számára megfelelő helyen - töl- 
gyesekben - és megfelelő időpontban keressük. Higanygőzlámpa fényére már alkonyatkor repül, nem ritkán akár 10-20 példányát is lehet látni egy este.

Az Acronicta alni is azon fajok közé tartozik, amelynek elterjedését korábban alig ismerték, hiszen első hazai előfordulását csak 1957-ben jelezték, és még a hetvenesnyolcvanas években is alig volt bizonyítópéldány a Magyar Természettudományi Múzeum gyüjteményében. Tapasztalataim szerint a Dél- és Nyugat-Dunántúl csaknem minden táján elterjedt és nem különösebben ritka, a Nyugat-Mecsek Tájvédelmi körzetben több helyen számos példánya került elö. Nevével ellentétben (,alni” = éger) nálunk minden bizonnyal polifág, tölgyön is élö faj.

Meg kell emlékeznünk a nagyon látványos küllemü Antherea yamamai mecseki térhódításáról is. Kovács (1957) számolt be első hazai előfordulásáról. Két évtizeddel később már többfelé észlelték Vas, Zala és Somogy megyékben (UHERKovich 1978b). A Zselic baranyai részén a nyolcvanas évek elején helyenként már tömegesen fordult elö (UHERKOVICH 1982). A nyolcvanas évek végén vagy a kilencvenes években jelent meg a Mecsekben. Mintegy 20 évvel ezelött már többfelé előfordult, bár gyakorinak sehol sem mondható. Mecseki adatainak többsége a 2000-es évekből származik. Amíg régebbi előfordulási helyei inkább a síkvidéki kocsányos tölgyesek elterjedésével estek egybe, mára ennél sokkal szárazabb termőhelyeken is felbukkan, például a hegység délies lejtőin is, ahol minden valószínüség szerint nem kocsányos tölgyön, hanem valamelyik másik tölgy fajon fejlödik.

\section{Vándorlepkék}

Egy korábbi munkámban foglalkoztam a dél-dunántúli vándorlepkékkel (UHERKOVICH 1979). A lepkevándorlások egyes fajok esetén rendszeresek (pl. Vanessa cardui, $V$. atalanta, Agrius convolvuli), ezek a fajok minden évben rendszeresen és többnyire nagyobb egyedszámban vonulnak északra a Mediterráneumból a tavasz vége felé, vagy a nyár elején. E fajok itt fejlődő nemzedéke általában meglehetősen egyedgazdag.

Ezzel szemben más fajok csak az utóbbi években váltak rendszeres és tömeges vándorokká. Közülük is ki kell emelni a Helicoverpa armigera fajt, amely az elmúlt egy-két évtizedben vált tömeges vándorrá, mostanra a vándorlepkék közül a leggyakoribb, egyegy este akár több tucatnyi példát láthatjuk lámpák körül. A két közelrokon faj, a Heliothis nubigera és a $H$. peltigera viszont észrevehetően megritkult.

A tájvédelmi körzet területén számos egyéb vándorlepke-faj jelent meg kisebb-nagyobb egyedszámban.

Kifejezetten ritkán láttuk az Orthonama obstipata, Eublemma parva és Eublemma purpurina fajokat, némelyikböl csak egy-két példányt az elmúlt évtizedekben. Ugyanígy az Acherontia atropos is rendkívül ritkán jelenik meg, bizonyító példánya csak Cserkútról van, még a nyolcvanas évek elejéről.

A Spodoptera exigua vagy a Peridroma saucia időnként gyakori lehet, máskor évekig nem találkoztunk velük. Csak a legújabb időkben jelent meg itt a Rhodometra sacraria, Trichoplusia ni és a Lampides boeticus, bár más tájakon - például a Villányi-hegységben - egy-egy példányukkal már évtizedekkel ezelőtt is találkozhattunk. Mindhárom említett fajt a Pécs feletti Deindolokban láttuk az utóbbi egy-két évben. Ugyancsak nem volt régebbi adata a Noctua interjecta fajnak innét, bár első hazai felbukkanása (Hedrehely, Zselic: UHERKOVICH 1980b) óta néhányszor már gyüjtötték másutt. A tájvédelmi körzetben a kétezres években észleltük néhány példányát.

Úgy tünik, hogy a Colias croceus is - amely évtizedekkel ezelőtt kifejezetten gyakori vagy tömeges volt - némileg visszaszorult.

A korábban inkább vándorlepkének tartott Dysgonia algira (GoZMÁNY 1970) szinte biztos, hogy nem vándor, hanem honos, helyben folyamatosan tenyésző faj, mert egye- 
dei rendszeresen, gyakran, szinte kiszámíthatóan jelennek meg a legtöbb élöhelyen. Ugyancsak valószínütlen a Libythea celtis vándorlepke-státusa, hiszen ez is eléggé rendszeresen - de az előbbinél sokkal ritkábban - látható, gyakran már kora tavasszal is, a többi áttelelő Nymphalidával együtt.

Meg kell jegyezni, hogy enyhe télen egy alkalommal januárban is láttunk Vanessa atalantát - kérdés, hogy a telelése a továbbiakban sikeres volt-e? Nem elképzelhetetlen, hogy egyes, nagyon enyhe teleken - néhány ilyent megfigyeltek már a Mecsekben az utóbbi egy-két évtizedben - némelyik vándorlepkének tartott állat imágója áttelel, és kora tavasszal is megfigyelhető. Erre utalnak bizonyos korai, márciusi-áprilisi vándorlepke észlelések.

\section{Eltünö és megjelenö fajok}

Amint azt már említettük néhány védett faj kapcsán, több faj teljesen eltünt vagy alaposan megritkult az elmúlt öt évtizedben, illetve mások csak ennek a vizsgálati időszaknak a vége felé jelentek meg a tájvédelmi körzet területén.

Az eltünő fajok egyik példája a mostani vizsgálatokban ki sem mutatott (bár több esetben célzottan keresett) Erannis ankeraria. Ez a faj az ötvenes években még előfordult a pécsi Mecsekben, de sem a pontosan ismert „klasszikus” lelőhelyén, sem hasonló adottságokkal rendelkező élőhelyeken nem sikerült újabb példányaira lelnünk.

A védett fajok közül az Iolana iolas egyedszáma és elterjedési területe jelentősen csökkent, bár ez a faj még nem tünt el. Viszont a védett Ocnogyna parasita, amelyik a nyolcvanas években még viszonylag magas egyedszámmal fordult elö a mintákban, a kilencvenes években megritkult és 1993 után már egyetlen példányát sem láttuk.

Hasonlóképpen nagyon látványos volt a Perigrapha i-cinctum teljes eltünése a kilencvenes évek elején: 1991-ben került elő utolsó nyugat-mecseki példánya a Deindolokban. Ugyancsak szinte teljesen eltüntek - vagy legalábbis nagyon megritkultak - az Apamea-fajok, amelyek többsége fokozott nedvességigényü, leginkább magaskórósokra jellemző faj. Ugyancsak alig lehet látni a három Photedes fajt (Ph. fluxa, Ph.minima, Ph. extrema) a kilencvenes évek óta.

A Diarsia brunnea még a nyolcvanas években rendszeres volt az északi völgyekben (Nagy-Mély-völgy). Akkor úgy tünt, hogy hasonlóan más nedvességkedvelő fajokhoz, terjedőben van. Az elmúlt 30 évben a terjedést regresszió váltotta fel, és ezt a fajt sem fogtuk sem a tájvédelmi körzetben, sem a másutt a környéken a Dél-Dunántúlon.

Nagyon sok olyan faj él a Nyugat-Mecsek TK-ben, amelyek mára megritkultak, vagy esetleg újabb példányokat nem is láttunk belölük. A teljesség igénye nélkül néhány ilyen faj: Pelurga comitata, Eulithis mellinata, Eupithecia subfuscata, Ourapteryx sambucaria, Synopsia sociaria, Fagivorina arenaria, Macaria brunneata, Mythimna conigera, M. impura stb.

A vándorlepkék közül a halálfejes lepke (Acherontia atropos) gyakorlatilag teljesen eltünt, a nyolcvanas évek óta nem láttuk itt. Ennek nemcsak helyi okai lehetnek, hanem eredeti élőhelyein, a Mediterráneumban is valószínűleg csökkent népessége.

A nappalilepkék közül eltünőben van számos faj. A Spialia orbifer, Carterocephalus palaemon, Heteropterus morpheus és a Cupido minimus kilencvenes évek után nagyon megritkult illetve a legtöbb élőhelyéről eltűnt. Ezek ökológiai igényei meglehetősen különbözőek, mégis mindhárom napjainkra nagyon megritkult. Teljesen eltünt a kilencvenes évek eleje óta a Leptidea morsei major, utolsó példányát 1991-ben láttam. Hasonlóan teljesen eltűnt nemcsak a tájvédelmi körzetből, hanem az egész DélDunántúlról az Aporia crataegi. Utolsó példányait még a hatvanas években láttuk itt és a környéken. Ugyancsak eltünőben van, az elmúlt 10-15 évben már nem láttam a Polyommatus daphnis és az Argynnis adippe fajokat. 
A Zerynthia polyxena élőhelyei gyorsan változnak, attól függően, hogy a tápnövénye, a farkasalma hogyan jelenik meg illetve tünik el. A Mecsek délies lejtőin fekvő szőlők a tápnövénynek illetve magának a lepkének is alkalmas életteret biztosítanak, de a szőlők felhagyása után a tápnövény és ezzel együtt a lepke is eltünik. Így a Deindolokban élő népes populáció is elszegényedett, 2010 körül már csak néha láttunk egy-egy példányt.

A Neozephyrus quercus ugyancsak megritkult az elmúlt néhány évben, de még így is számos példányát lehetett látni rajzási idejében.

Ugyancsak nagyon változó volt az utóbbi évtizedekben a Parnassius mnemosyne populációinak mérete. Néhány évvel ezelőtt csak egy-egy példányukat lehetett látni, mára egy kissé erősödtek ezek a populációk.

A fentiekkel szemben van néhány olyan faj - jóval kevesebb! - amelyeket vizsgálataim elején, a hatvanas-hertvenes, sőt még a nyolcvanas években sem gyüjtöttem. Jól ismert a Colias erate hazai megtelepedése. A vizsgálati területen a kilencvenes években észleltük először, azóta rendszeresen látjuk és nem ritka. Ugyancsak jól ismert a Libythea celtis eltűnése az ötvenes években, majd évtizedekkel későbbi újbóli megjelenése. A kétezres években a Nyugat-Mecsek TK-ben is több példányát láttuk, elsősorban kora tavaszi, áttelelö példányokat.

Az Aedia leucomelas és az Antherea yamamai húsz-harmic évvel ezelőtti megjelenéséről az előző alfejezetben már szóltam.

Az újonnan felbukkanó vagy sokkal gyakoribbá váló fajok közé olyanok is tartoznak, amelyek a fenyőfélék betelepítése nyomán tápnövényüket követik. Így például a Thera variata-nak korábban alig volt nyugat-mecseki adata, ma elég gyakorinak mondható, különösen, ha telepített lucfenyő vagy valami hasonló fenyő-faj található a közelben. Ugyanígy például a Deindolokban mostanában jelent meg a Macaria liturata is.

A polifág lombfogyasztó, de ennek ellenére meglehetősen ritka, imágó formában áttelelö Chloroclysta siterata hosszú idő után újra 2011-ben jelent meg, ekkor három helyen láttuk.

A fenti tendenciák a normálisnak tekinthető egyedszám-ingadozásokon túlmutatnak. A napfolt-tevékenységgel párhuzamba állítható egyedszám változásokról még a hetvenes években írtunk (VARGA, UHERKOVICH 1974). Ezek szerint, különösen egyes lombfogyasztók esetében (pl. Operophtera brumata, Erannis defoliaria, Agriopis aurantiaria, Dichonia convergens stb.) egy szabályosságot mutató, 10-12 éves ciklus szerint változik az egyedszám. A maximumban (gradációban) az egyedszám a minimum-értékek tízszerese vagy akár többszázszorosa is lehet. Ennek pontos nyomonkövetéséhez a fénycsapdák nagy tömegü anyagának feldolgozása szükséges, egyébként a ritkább mintavételek torzító hatása nagyobb lehet, mint a populációk méretváltozásai.

A fajszám - azaz a biodiverzitás - csökkenése évtizedek óta tartó folyamat. Ezen belül vannak időszakok, amikor bizonyos fajok, például egyes nedvességkedvelő vagy montán elemek átmenetileg visszatérhetnek, illetve populációik megerösödhetnek. Ilyen időszaknak tekinthetö a hetvenes évek és nyolcvanas évek eleje. Azóta viszont sok fajt egyáltalán nem láthattunk. Hatalmas mennyiségü jegyzőkönyvi anyag és fénycsapdanapló feldolgozásán keresztül viszont egyértelmüen kimutatható lenne az egyes fajok megritkulása vagy eltünésének ideje. De csak ennek a tájegységnek illetve tájvédelmi körzetnek az adatai is jól rávilágítanak a biodiverzitás erőteljes csökkenésére. Ezt a tényt egyértelmüen a kedvezőtlen klímaváltozás egyik bizonyítékának tartom. 


\section{Köszönetnyilvánítás}

Mindenekelött Nógrádi Sárának kell köszönetet mondanom a gyüjtésekben nyújtott segítségért. Ötvös Károly a rendelkezésemre bocsátotta művészi színvonalú lepkefotóit, amelyek legnagyobb része Abaligeten készült (néhány értékes fényképe pedig a tájvédelmi körzet más pontjain). Gergely Tibor a kétezres években sokszor részt vett és segített az éjszakai gyüjtésekben. Ábrahám Levente pedig ösztönzött jelen cikk megírására, és emellett hasznos segítséget nyújtott az egyes fajokról írtak kiegészítésére.

2. táblázat: Védett és *fokozottan védett fajok (a 66/2015 (X. 26.) FM rendelet 2. melléklete alapján)

\begin{tabular}{|c|c|c|}
\hline $\begin{array}{c}\text { A faj tudományos neve szerzővel, évszámmal } \\
\text { (jelen cikkben szereplő névvel) }\end{array}$ & A faj magyar neve & $\begin{array}{c}\text { Természetvé- } \\
\text { delmi értéke } \\
\text { HUF }\end{array}$ \\
\hline Eriogaster catax (Linnaeus, 1758) & Sárga gyapjasszövő & 50000 \\
\hline Eriogaster lanestris (Linnaeus, 1758) & Tavaszi gyapjasszövő & 10000 \\
\hline Acherontia atropos (Linnaeus, 1758) & Halálfejes lepke & 10000 \\
\hline Marumba quercus ([Denis \& Schiffermüller], 1775) & Tölgyfaszender & 10000 \\
\hline Proserpinus proserpina (Pallas, 1772) & Törpeszender & 50000 \\
\hline Saturnia pavoniella (Scopoli, 1763) & Kis pávaszem & 10000 \\
\hline Saturnia pyri ([Denis \& Schiffermüller], 1775) & Nagy pávaszam & 50000 \\
\hline Aglia tau (Linnaeus, 1758) & T-betüs pávaszem & 5000 \\
\hline Archiearis notha (Hübner, 1803) & Vörhenyes nappaliaraszoló & 5000 \\
\hline Orthostixis cribraria (Hübner, 1799) & Pettyes fehéraraszoló & 50000 \\
\hline Entephria caesiata ([Denis \& Schiffermüller], 1775) & Szürke hegyiaraszoló & 10000 \\
\hline Chesias rufata (Fabricius, 1775) & Vöröses zanótaraszoló & 10000 \\
\hline Dyscia conspersaria ([Denis \& Schiffermüller], 1775) & Sziklaüröm-araszoló & 5000 \\
\hline Perconia strigillaria (Hübner, 1787) & Fehérszárnyú aranyaraszoló & 10000 \\
\hline Dicranura ulmi ([Denis \& Schiffermüller], 1775) & Szilfa-púposszövő & 5000 \\
\hline Drymonia velitaris (Hufnagel, 1766) & Hegyi púposszövö & 10000 \\
\hline Phalera bucephaloides (Ochsenheimer, 1810) & Magyar púposszövő & 10000 \\
\hline Polypogon gryphalis (Herrich-Schäffer, 1851) & Láperdei karcsúbagoly & 5000 \\
\hline Ocnogyna parasita (Hübner, 1790) & Csonkaszárnyú medvelepke & 50000 \\
\hline Diaphora luctuosa (Geyer, 1833) & Gyászos medvelepke & 50000 \\
\hline Euplagia quadripunctaria (Poda, 1761) & Csíkos medvelepke & 5000 \\
\hline Tyria jacobaeae (Linnaeus, 1758) & Jakabfü-lepke & 5000 \\
\hline
\end{tabular}




\begin{tabular}{|c|c|c|}
\hline $\begin{array}{c}\text { A faj tudományos neve szerzővel, évszámmal } \\
\text { (jelen cikkben szereplő névvel) }\end{array}$ & A faj magyar neve & $\begin{array}{c}\text { Természetvé- } \\
\text { delmi értéke } \\
\text { HUF }\end{array}$ \\
\hline *Arytrura musculus (Ménétriés, 1859) & Keleti lápibagoly & 250000 \\
\hline Catocala dilecta (Hübner, 1808) & Nagy övesbagoly & 10000 \\
\hline Diachrysia chryson (Esper, 1789) & Nagyfoltú aranybagoly & 50000 \\
\hline Autographa jota (Linnaeus, 1758) & i-betűs aranybagoly & 10000 \\
\hline Shargacucullia gozmanyi G. \& L. Ronkay, 1994 & Gozmány-csuklyásbagoly & 10000 \\
\hline Shargacucullia prenanthis (Boisduval, 1840) & Tavaszigörvélyfü-csuklyásbagoly & 5000 \\
\hline Cucullia chamomillae ([Denis \& Schiffermüller], 1775) & Székfü-csuklyásbagoly & 5000 \\
\hline Periphanes delphinii (Linnaeus, 1758) & Szarkalábbagoly & 10000 \\
\hline Heteropterus morpheus (Pallas, 1771) & Tükrös busalepke & 10000 \\
\hline Spialia orbifer (Hübner, 1823) & Törpe busalepke & 10000 \\
\hline Pyrgus alveus (Hübner, 1803) & Hegyi busalepke & 10000 \\
\hline Zerynthia polyxena ([Denis \& Schiffermüller], 1775) & Farkasalmalepke & 50000 \\
\hline Parnassius mnemosyne (Linnaeus, 1758) & Kis apollólepke & 50000 \\
\hline Iphiclides podalirius (Linnaeus, 1758) & Kardoslepke & 10000 \\
\hline Papilio machaon Linnaeus, 1758 & Fecskefarkú lepke & 10000 \\
\hline Gonepteryx rhamni (Linnaeus, 1758) & Citromlepke & 5000 \\
\hline Leptidea morsei major Grund, 1905 & Keleti mustárlepke & 50000 \\
\hline Lycaena dispar rutila Werneburg, 1864 & Nagy tűzlepke & 50000 \\
\hline Lycaena thersamon (Esper, 1784) & Kis tűzlepke & 10000 \\
\hline Neozephyrus quercus (Linnaeus, 1758) & Tölgyfalepke & 5000 \\
\hline Thecla betulae (Linnaeus, 1758) & Nyírfa-csücsköslepke & 5000 \\
\hline Satyrium w-album (Knoch, 1782) & Szilfa-csücsköslepke & 10000 \\
\hline Satyrium pruni (Linnaeus, 1758) & Szilvafa-csücsköslepke & 5000 \\
\hline Satyrium spini ([Denis \& Schiffermüller], 1775) & Kökény-csücsköslepke & 10000 \\
\hline Satyrium ilicis (Esper, 1779) & Tölgyfa-csücsköslepke & 10000 \\
\hline Cupido alcetas (Hoffmannsegg, 1804) & Palakék boglárka & 5000 \\
\hline Cupido decolorata (Staudinger, 1886) & Fakó boglárka & 5000 \\
\hline Pseudophilotes schiffermuelleri (Hemming, 1929) & Apró boglárka & 10000 \\
\hline *Iolana iolas (Ochsenheimer, 1816) & Magyar boglárka & 250000 \\
\hline Glaucopsyche alexis (Poda, 1761) & Nagyszemes boglárka & 5000 \\
\hline Aricia agestis ([Denis \& Schiffermüller], 1775) & Szerecsenboglárka & 5000 \\
\hline Libythea celtis (Laicharting, 1782) & Csőröslepke & 5000 \\
\hline Limenitis reducta Staudinger, 1901 & Kék lonclepke & 50000 \\
\hline Neptis rivularis (Scopoli, 1763) & Nagy fehérsávoslepke & 10000 \\
\hline Neptis sappho (Pallas, 1771) & Kis fehérsávoslepke & 10000 \\
\hline Argynnis paphia (Linnaeus, 1758) & Nagy gyöngyházlepke & 5000 \\
\hline Brenthis daphne ([Denis \& Schiffermüller], 1775) & Málna gyöngyházlepke & 5000 \\
\hline Boloria euphrosyne (Linnaeus, 1758) & Árvácska gyöngyházlepke & 5000 \\
\hline
\end{tabular}




\begin{tabular}{|l|l|c|}
\hline \multicolumn{1}{|c|}{$\begin{array}{c}\text { A faj tudományos neve szerzővel, évszámmal } \\
\text { (jelen cikkben szereplö névvel) }\end{array}$} & \multicolumn{1}{|c|}{ A faj magyar neve } & $\begin{array}{c}\text { Természetvé- } \\
\text { delmi értéke } \\
\text { HUF }\end{array}$ \\
\hline Boloria selene ([Denis \& Schiffermüller], 1775) & Fakó gyöngyházlepke & 10000 \\
\hline Apatura ilia ([Denis \& Schiffermüller], 1775) & Kis színjátszólepke & 10000 \\
\hline Apatura iris (Linnaeus, 1758) & Nagy színjátszólepke & 50000 \\
\hline Euphydryas maturna (Linnaeus, 1758) & Díszes tarkalepke & 50000 \\
\hline Melitaea trivia ([Denis \& Schiffermüller], 1775) & Kis tarkalepke & 5000 \\
\hline Melitaea aurelia Nickerl, 1850 & Recés tarkalepke & 10000 \\
\hline Nymphalis io (Linnaeus, 1758) & Nappali pávaszem & 5000 \\
\hline Nymphalis urticae (Linnaeus, 1758) & Kis rókalepke & 50000 \\
\hline Nymphalis polychloros (Linnaeus, 1758) & Nagy rókalepke & 10000 \\
\hline Nymphalis antiopa (Linnaeus, 1758) & Gyászlepke & 50000 \\
\hline Nymphalis c-album (Linnaeus, 1758) & c-betüs lepke & 5000 \\
\hline Vanessa atalanta (Linnaeus, 1758) & Atalantalepke & 5000 \\
\hline Pyronia tithonus (Linnaeus, 1767) & Kis ökörszemlepke & 10000 \\
\hline Arethusana arethusa ([Denis \& Schiffermüller], 1775) & Közönséges szemeslepke & 5000 \\
\hline
\end{tabular}

\section{Irodalom}

ABAFI-Aiger L. 1907: Magyarország lepkéi. - Budapest, pp. 137+ XXXII.

ÁBRAHÁm L. és UHERKovich Á. 1998: A Dráva mente nagylepkefaunája és jellegzetes élőhelyei. - Dunántúli Dolgozatok Természettudományi Sorozat 9: 359-385.

Ábrahám, L. és Uherkovich Á. 2000: A nagylepke (Lepidoptera) fauna kutatásának eddigi eredményei a Villányi-hegységben. - Dunántúli Dolgozatok Természettudományi Sorozat 10: 309-339.

Balogh I. 1956: Öszi és tavaszi lepidopterológiai megfigyelések Pécsett. - Pécsi Pedagógiai Főiskola Évkönyve 1955/56: 1-5.

BARANYI T. 2003: A keleti lápibagoly (Arytrura musculus) és a Metelka-medvelepke (Rhyparoides flavidus metelkanus) előfordulásai a Dél-Nyírségben (Lepidoptera). - Folia entomologica hungarica 64: 357-361.

GozmÁNY L. 1970: Bagolylepkék I. Noctuidae I. - Fauna Hungariae 16 (11): 1-151.

Gyulai I., Gyulai P., Uherkovich Á. és Varga Z. 1979: Újabb adatok a magyarországi nagylepkék elterjedéséhez II. - Folia entomologica hungarica 32: 219-227.

Kovács L. 1953: A magyarországi nagylepkék és elterjedésük. - Folia entomologica hungarica 6: 77-184.

Kovács L. 1956: A magyarországi nagylepkék és elterjedésük, II. - Folia entomologica hungarica 9: 89-140.

Kovács L. 1957: A magyar nagylepkefauna gyarapodása 1956-ban. - Folia entomologica Hungarica 10: 125-132.

Lovász Gy. 1977: Baranya megye természeti földrajza. - Baranya megyei Levéltár, Pécs, pp. 384.

Magyar Közlöny, 2015. A földmüvelésügyi miniszter 66/2015 (X. 26.) FM rendelete az elkobzott védett természeti értékekkel kapcsolatos intézkedésekről szóló 19/1997 (VII. 4.) KTM rendelet, valamint a védett és a fokozottan védett növény- és állatfajokról, a fokozottan védett barlangok köréröl, valamint az Európai Közösségben természetvédelmi szempontból jelentős növény- és állatfajok közzétételéröl szóló 13/2001 (V. 9.) KöM rendelet módosításáról. - Magyar Közlöny 2015 (158): 20844-20949.

MaLGaY V. és BrunNER J., L. 2011: Egy újabb adat a keleti lápibagoly (Arytrura musculus Ménétriés, 1859) hazai előfordulásához. - Natura Somogyiensis 19: 247-250.

NÉMETH L. és SzABóKy Cs. 1998: A keleti lápibagoly (Arytrura musculus Ménétries, 1859) újabb hazai adatai (Lepidoptera: Noctuidae). - Folia entomologica hungarica 59: 310-313.

UHERKOVICH Á. 1977: Adatok Baranya nagylepkefaunájának ismeretéhez V. A gilvánfai Szilas-erdő nagylepkéi. - A Janus Pannonius Múzeum Évkönyve 19 (1974): 63-83. 
Uherkovich Á. 1978a: Adatok Baranya nagylepkefaunájának ismeretéhez VIII. Mecseki karsztbokorerdők nagylepkéi. - A Janus Pannonius Múzeum Évkönyve (1977) 22: 61-72.

Uherkovich Á. 1978b: Komlósd környékének nagylepkefaunája (Macrolepidoptera). - A Janus Pannonius Múzeum Évkönyve (1977) 22: 73-87.

Uherkovich Á. 1979: Vándorlepke-megfigyelések a Dél-Dunántúlon, 1966-1977 (Lepidoptera). - A Janus Pannonius Múzeum Évkönyve (1978) 23: 51-70.

Uherkovich Á. 1980a: Adatok Baranya nagylepkefaunájának ismeretéhez X. Egy mecseki cseres-tölgyes nagylepkéi (epidoptera). - A Janus Pannonius Múzeum Évkönyve (1979) 24: 63-75.

UherKovich Á. 1980b: A Noctua interjecta Hbn. magyarországi előfordulása (Lepidoptera: Noctuidae). Folia entomologica hungarica 41 (33): 378.

Uherkovich, Á. 1981: Data to the Macrolepidoptera Fauna of South Transdanubia (Lepidoptera), II. - Folia entomologica hungarica 42 (34): 239-252.

Uherkovich Á. 1982: A Zselic nagylepkefaunája II. Délkelet-Zselic (Lepidoptera). - A Janus Pannonius Múzeum Évkönyve (1980) 26: 33-50.

Uherkovich Á. 1983: Az Entephria caesiata Den. et Schiff. mecseki előfordulásáról (Lepidoptera). - Folia entomologica hungarica 44: 340.

Uherkovich Á. 1984: A mecseki Nagy-mély-völgy nagylepkefaunája és a Délnyugat-Dunántúl bükkön élő faunaelemei (Lepidoptera). - A Janus Pannonius Múzeum Évkönyve (1983) 28: 23-37.

Uherkovich Á. 1985: Néhány további adat a Barcsi borókás nagylepke faunájához (Lepidoptera). - Dunántúli Dolgozatok Természettudományi sorozat 5: 236-238.

Uherkovich Á. 1987: További lepkészeti adatok a Nyugati-Mecsekből (Lepidoptera). - A Janus Pannonius Múzeum Évkönyve (1985-86) 30-31: 23-32.

Uherkovich Á. 1990: Kisdobsza nagylepkefaunája (Lepidoptera). - A Janus Pannonius Múzeum Évkönyve 34 (1989): 73-80.

Uherkovich Á. és Áвrahám L. 1995: A nagylepke (Lepidoptera: Macrolepidoptera) kutatások faunisztikai eredményei a Dráva mentén. - Dunántúli Dolgozatok Természettudományi Sorozat 8: 139-159.

Uherkovich Á. és Ábrahám L. 2007: A keleti lápibagolylepke - Arytrura musculus (Ménétriés, 1859) (Lepidoptera: Noctuidae) előfordulása a Zselicben. - Natura Somogyiensis (Kaposvár) 10: 361-363.

Varga Z. (ed.) 2012: Magyarország nagylepkéi. Macrolepidoptera of Hungary. 2nd Ed. - Heterocera Press, Budapest, pp. 256.

VARGA, Z. és UhERKovich, Á. 1974: Die Anwendung der Lichtfallen in der ökologischen Landschaftsforschung. - Folia entomologica hungarica 27 (Suppl.): 159-171. 